DANMARKS GEOLOGISKE UNDERSØGELSE

Serie B, Nr. 4

Geological Survey of Denmark. Series B, No. 4

\title{
Lithostratigraphy and depositional history of the Danish Triassic
}

BY

Finn Bertelsen

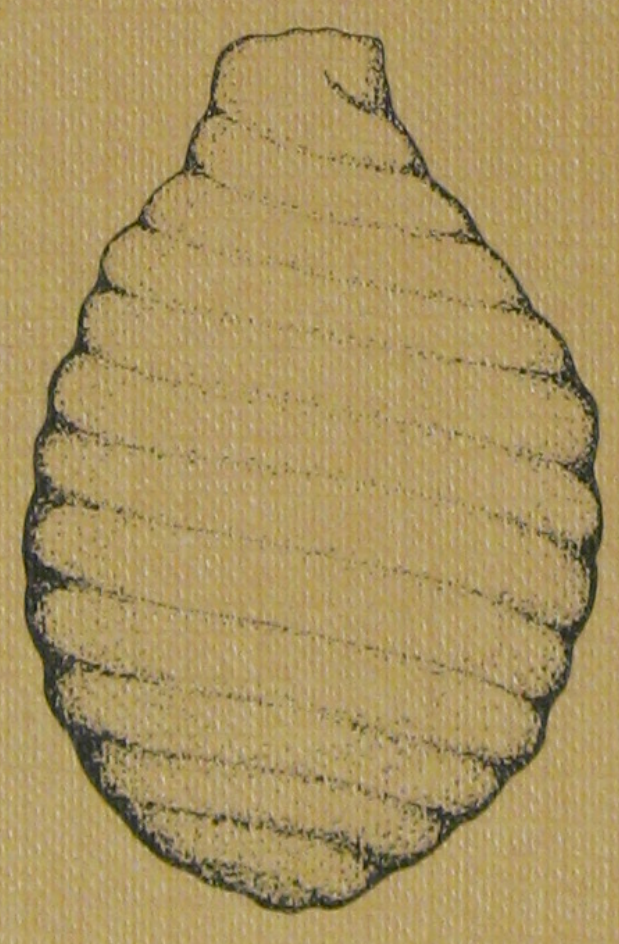


Danmarks Geologiske Undersøgelse. Serie B, Nr. 4

Geological Survey of Denmark. Series B, No. 4

\section{Lithostratigraphy and depositional history of the Danish Triassic}

by

Finn Bertelsen

I kommission hos C. A. Reitzels Forlag. København 1980 
D.G.U. Serie B, nr. 4

er sat med Foto Times

og trykt $i$ offset i 1000 eksemplarer

hos AiO Tryk as, Odense

Bogen er trykt på Thai-Cote, $115 \mathrm{~g}$

fra a/s De forenede Papirfabrikker.

ISBN 87-421-(0721-0

Date of publication: $1980-02-22$

Adress of the author:

F. Bertelsen

Holmevej 90,

9640 Farsø,

Denmark

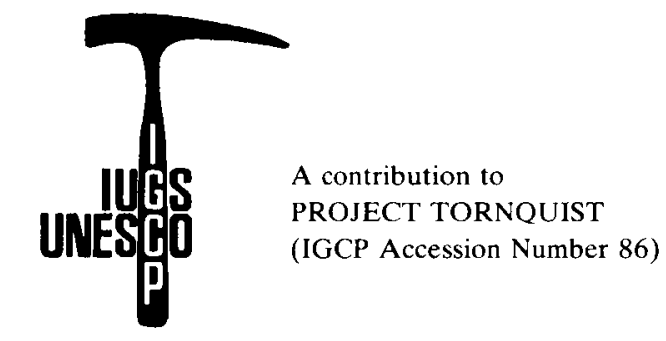

With 1 map (fig. 3) and 2 plates in pocket inside back cover. 


\section{Contents}

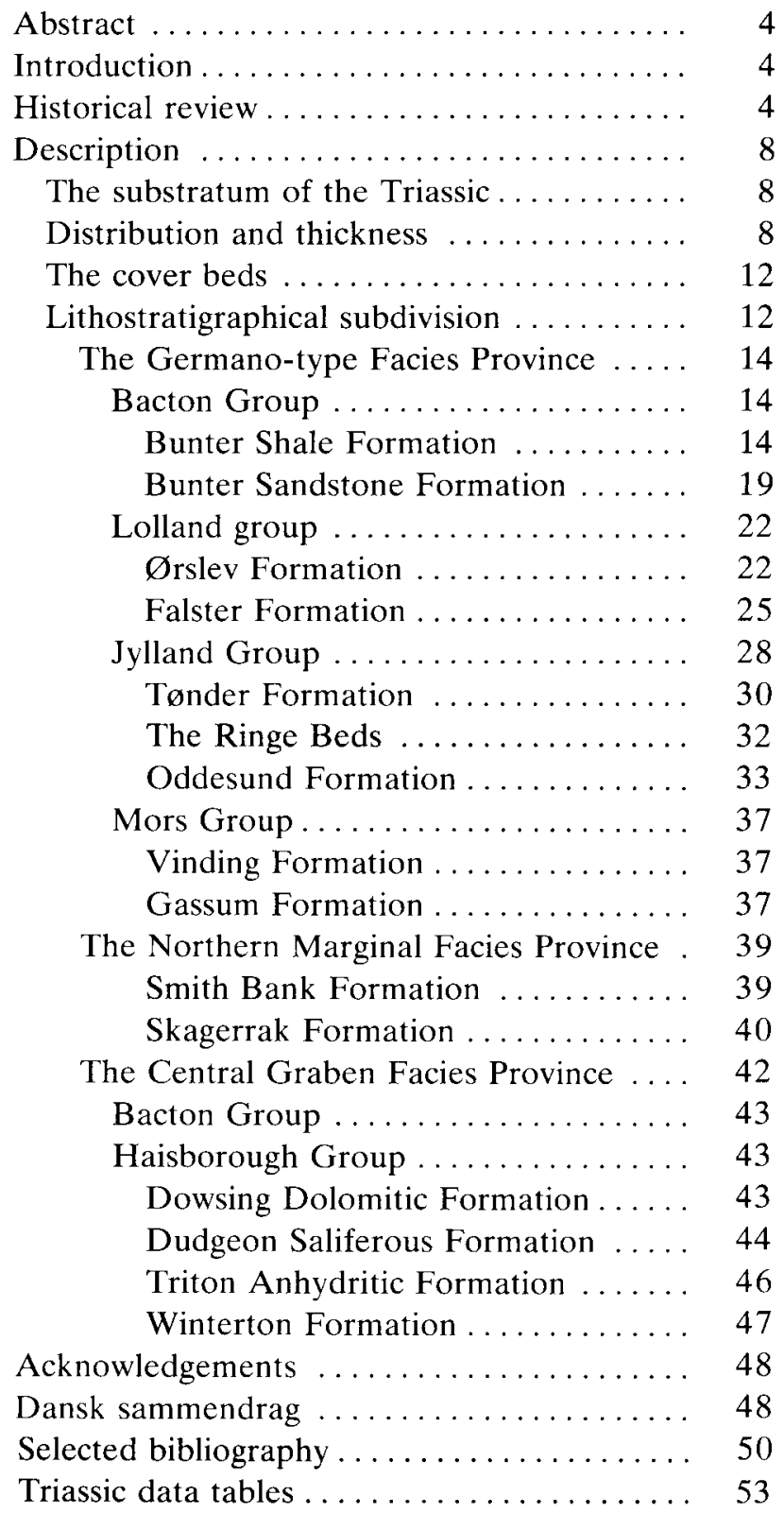




\section{Abstract}

The Triassic deposits of the Danish territory are mapped, described and characterized by means of wire line log motifs. Three facies provinces are recognized: A southern and central Germano-type Facies Province, a Northern Marginal Facies Province fringing the basin center, and a Central Graben Facies Province with affinities to the Southern North Sea Basin. The traditional German lithostratigraphic nomenclature previously used in the Germano-type Facies Province is proposed replaced by a system composed of four groups each of two formations corresponding to four Triassic megaphases of sedimentation: Bacton Group including Bunter Shale Formation and Bunter Sandstone Formation, Lolland Group (new) including Ørslev Formation (new) and Falster Formation (new), Jylland Group (new) including Tønder Formation (new) and Oddesund Formation (new), and Mors Group (new) including Vinding Formation and Gassum Formation. In the other facies provinces the nomenclature previously proposed for the Central and Southern North Sea is adopted. A summary of the basin evolution is given for each formation description.

\section{Introduction}

The Triassic series of the Danish area is almost exclusively known from deep wells drilled during exploration for hydrocarbons. Outcropping Triassic is only known from a limited coastal section on the island of Bornholm situated in the Baltic Sea, where a red coloured clay deposit is referred to the Keuper. There are however important natural outcrops and exposures in clay quarries with good sections of the youngest Triassic in the neighbouring Swedish province Skåne (Scania) where there are also many shallow and deep wells that contribute to the knowledge of the marginal deposits of the system. The nearest accessible older Triassic deposits are in the beautifully exposed cliffs of the German North Sea island of Helgoland.

The exploratory drilling for hydrocarbons in Denmark began in 1936. Since then more than 50 deep wells have been drilled in the onshore/offshore area excluding the Central Graben (map fig. 1). In the latter area more than 20 exploratory wells have been completed during the last decade. Although in many of these wells the Triassic has not been penetrated, much valuable information on the facies distribution and thickness of the series has been obtained. Combined, in part, with seismic data this information has been the basis for the interpretation of the Triassic series presented here. Further information, especially paleodatings from palynology, is however needed to permit a more precise presentation of the Triassic sedimentary history of the region. The present paper is therefore to be regarded as a status report on the Danish Triassic research.

The co-operative efforts of the petroleum industry and goverment authorities in recent years towards the establishment of a generally accepted lithostratigraphy for the Southern North Sea (Rhys 1974) and later on for the Central and Northern North Sea (Deegan \& Scull 1977) took place without Danish participation in the final stages of negotiations. As the lithostratigraphy proposed in the above mentioned papers also attempts to cover parts of Danish territory, and as it makes changes with the germano-type lithostratigraphy previously used in Denmark, it was felt necessary to redefine, update and discuss the local and regional lithostratigraphy. This work was initiated by the setting up of a local stratigraphic committee in 1975 , followed by the formation of subcommittees for the main stratigraphic units present in Denmark.

Structural and geographical terms as well as names used in the text are given on the maps figs. 1 and 2 .

\section{Historical review}

The initial work on the Danish Triassic series was carried out by the geologists of the Danish American Prospecting Company (DAPCo) which undertook the hydrocarbon exploration in the period 1935-1959. The reports of DAPCo were, however, never published, but copies were later stored in the files of the Danish Geological Survey (DGU). After some short papers on the stratigraphy of individual wells (Lavø 1 by Dinesen (1960) and Slagelse 1 by Larsen \& Buch (1960)), the DAPCo results were 


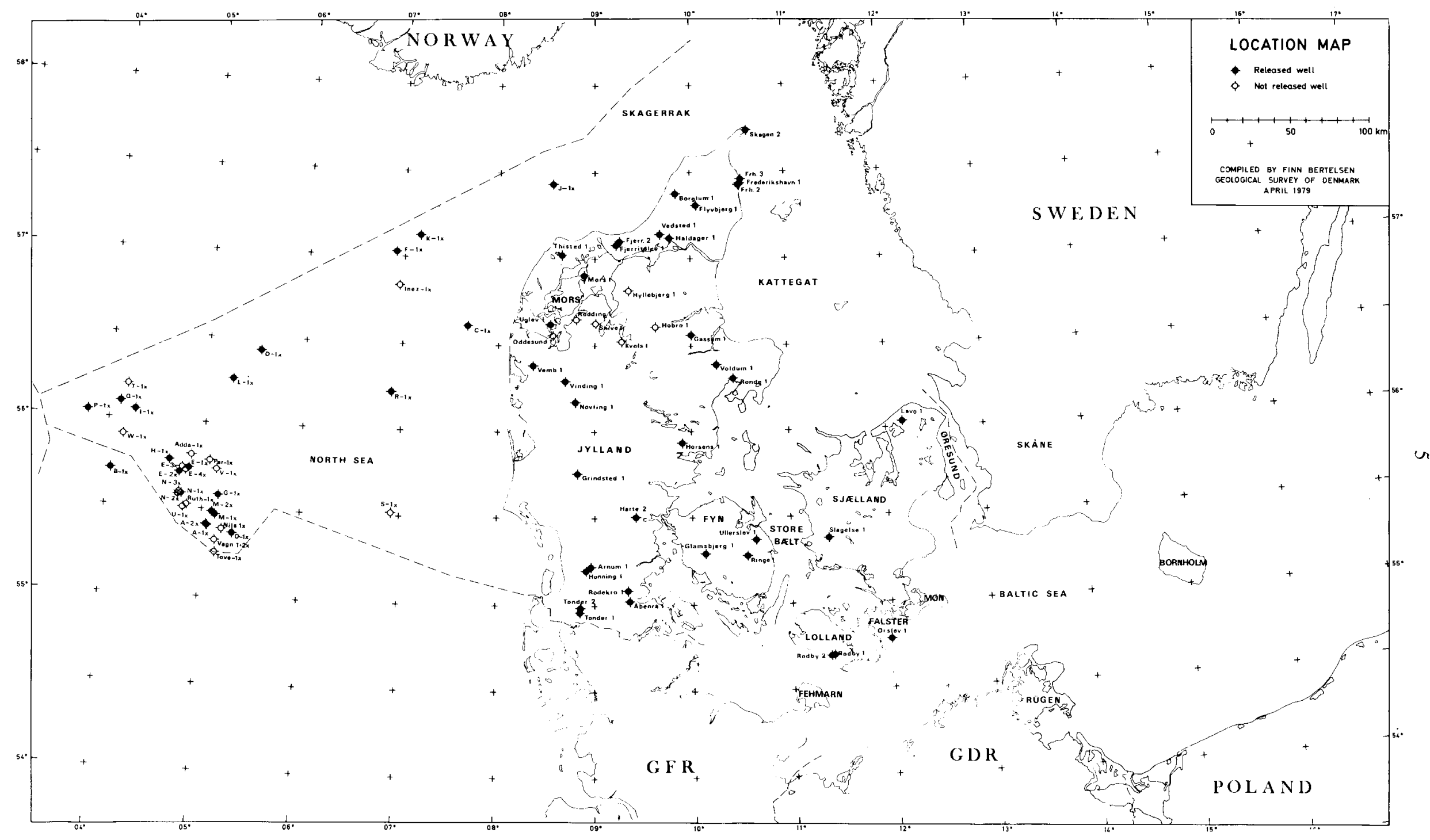

Fig. 1. Location map showing the position of deep Danish exploratory wells. "Released" means that the wells have passed a five year confidentiality period, after which data can be published by the Danish Geological Survey. 


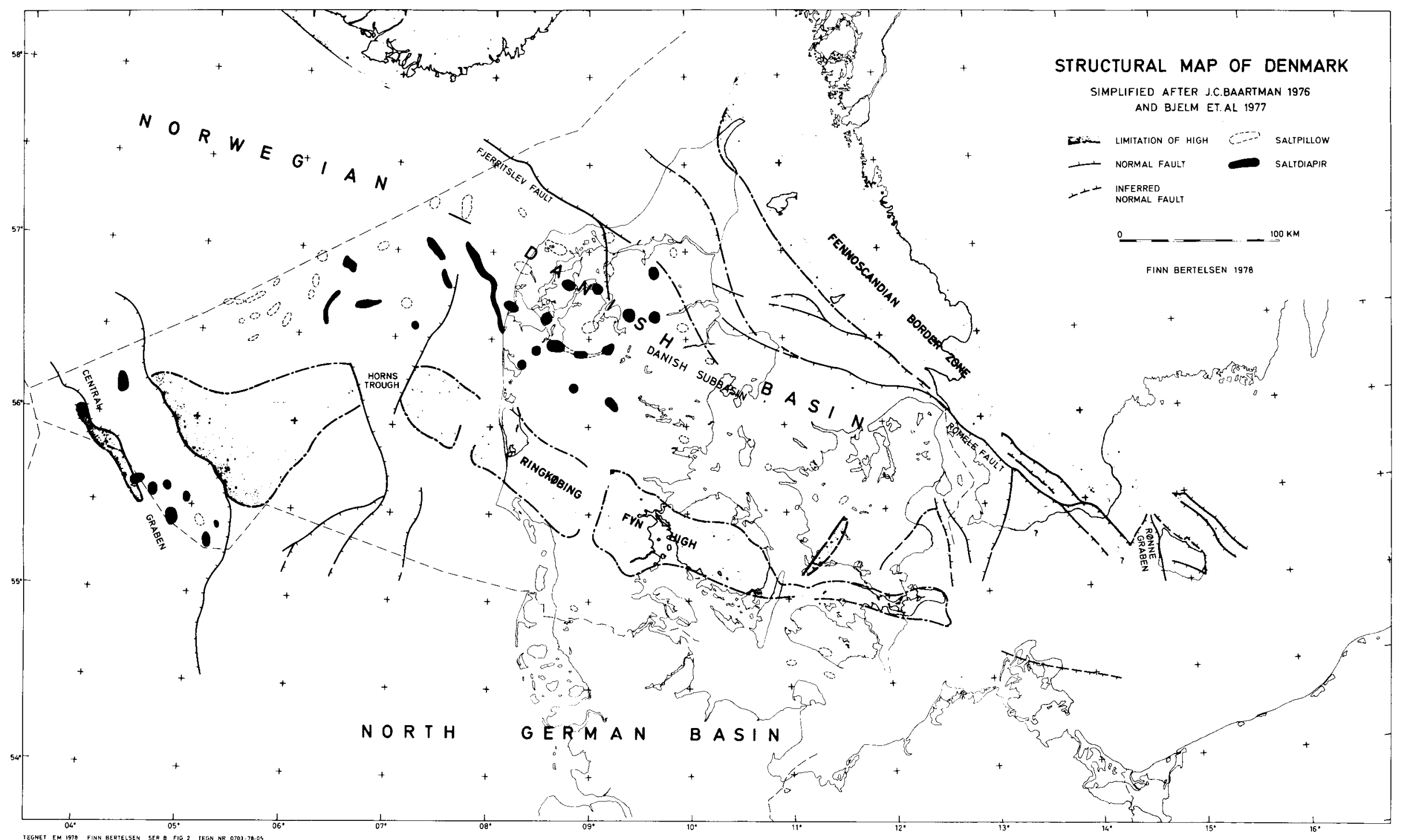

Fig. 2. Structural map of Denmark. Simplified after an unpublished map prepared by J. C. Baartman (D.G.U.) and adjusted in accordance with information given in Bjelm et al. (1977). 
summarized and published, with incorporated Survey data, by Sorgenfrei \& Buch (1964). In their important paper, the Triassic was subdivided in accordance with the German four-fold division into Buntsandstein, Muschelkalk, Keuper and Rhaetic. A short lithological description was given for each well section together with comments on the fossil content. Due to the general lack of fossils in the Triassic series their division was basically lithostratigraphic.

However a paper on Triassic biostratigraphy had already appeared in 1962. Christensen described the late Keuper - early Rhaetic ostracod faunas of the Harte 2 and Ullerslev 1 wells, and revised the stratigraphy of the two wells. The faunas were found to compare well with faunas described from the North German Basin.

In 1966, following a preliminary paper of 1964 , a study by Larsen dealt with the sedimentology, especially of heavy minerals, of the Rhaetic - Lower Cretaceous deposits of the Danish Embayment (here: Danish Subbasin). Larsen defined a number of local formations and discussed the depositional history. In the Triassic, the Vinding Formation was defined for Rhaetic marine claystones in the southwestern part of the basin, whereas the Gassum and Ullerslev Formations were proposed for the Rhatic fluvio-deltaic marginal deposits. With regard to the above-mentioned formations the lithological boundaries of Larsen correspond to those given in Sorgenfrei \& Buch (1964).

In 1970, the Rhaeto-Liassic of the Rødby 1 well was studied and revised by Bertelsen \& Michelsen, who used megaspores and ostracods for a biostratigraphic zonation of the section. The Triassic/Jurassic boundary was found to be marked by the appearance of a Nathorstisporites hopliticus megaspore - and an Ogmoconchella aspinata ostracod assemblage. This boundary is further discussed in Michelsen (1973, 1975 and 1978) and in Lund (1977).

In 1972, a review of the Mesozoic development of the Danish Subbasin (Danish Embayment) was given by Christensen. In dealing with the Triassic, the occurrence of ostracod assemblages in the upper part of the Muschelkalk section of the Rødby 1 well and in the Keuper sections known from shallow wells and outcrops on Bornholm was briefly discussed. Special attention was paid to the Triassic/Jurassic transition and Christensen pointed out the presence of oolitic limestones in the Lower Rhaetic ostracod bearing deposits. Otherwise the concepts of Larsen (1966) with regard to the facies distribution patterns of the basin were adopted by Christensen.

With the publication of the wells Rønde 1 in 1971 and Nøvling 1 in 1973 by the Geol. Survey (DGU), new information was given on fully penetrated Triassic sections in the Danish Subbasin. Dinesen (1971, 1973) described the lithology of the Triassic sections of both wells, while Christensen (1971, 1973) dealt with the litho- and biostratigraphy (ostracods) of the late Keuper and the Rhaetic beds. It was shown, that the ostracod faunas were of similar type as those described from the corresponding deposits in the North German Basin and in the Harte and Ullerslev wells.

The first information on the offshore Triassic is found in Rasmussen (1974). Rasmussen compiled the Survey studies of the first five exploration wells in the Danish North Sea sector. Included in the paper were the results of palynological studies by the present author which proved the presence of a Muschelkalk halite sequence in the A-2 well situated in the Central Graben area.

The results of further offshore palynological studies were published by Bertelsen (1975). The composition of the recovered microfloras was found similar to that of contemporaneous microfloras from U.K. and the Southern North Sea Basin published by Geiger \& Hopping (1968). The outline of the Triassic lithology of the A-2, F-1 and $\mathrm{K}-1$ wells was given.

In the same year a heavy mineral study of 14 Triassic borehole samples from various wells and stratigraphic levels was published by Friis \& Larsen (1975). The Buntsandstein of the south Danish north German region is included in a so-called "Garnet province" in which the clastic supply is thought to be of Scandinavian origin. The arkoses of the northernmost Frederikshavn and Skagen wells yielded heavy mineral associations of local origin. A titanite rich association from the Keuper of the Tønder 1 well seems to indicate, that the sediments were derived from exposed parts of the Ringkøbing - Fyn High. Parts of the results were, however, published earlier in a summary of a paper presented to the Danish Geological Society by Larsen (1967).

Lund (1977) presented a miospore zonation of the Triassic/Jurassic transitional series of the southeastern North Sea Basin. One of the key wells of this study was the Rødby 1 well, while other wells were situated in the North German Basin. The miospore zonation of Lund has later been found by the present author, to be applicable to the Danish Subbasin with only minor modifications. Lund, using the principles of Scott (reference in Lund 1977), also correlated the Rødby Rhaetic section with wells in NW Germany on the basis of clay colours, which in the Rhaetic seem to be surprisingly constant within wide areas.

Bertelsen (1978) revised the Upper Triassic - 
Lower Jurassic Vinding and Gassum Formations of the Norwegian - Danish Basin. The Vinding Formation is a brackish marine, shallow water deposit of late Norian - early Rhaetian age being characterized by dark grey claystones interbedded with dolomitic, in part oolitic, limestones and with characteristic ostracod faunas. The Gassum Formation is a predominantly fluvio-deltaic deposit of Rhaetian Sinemurian age. It conformably overlies the Vinding Formation in the center of the basin, and the two formations do not represent two contemporaneous facies as proposed by Larsen (1966).

It should further be mentioned, that the Triassic is dealt with in regional papers on the North Sea geology, of which some include Danish waters, e.g. Sorgenfrei (1969), Brennand (1975) and Ziegler (1977). Abbreviated profiles of the latest Danish offshore and onshore wells were published by Michelsen (1976) and by Rasmussen (1978). The lithostratigraphy of the Southern North Sea was published by Rhys (1974), and that of the Central and Northern North Sea by Deegan \& Scull (1977).

\section{Description}

\section{The substratum of the Triassic}

In major parts of the basins and troughs (cf. fig. 2) the Upper Permian (Zechstein) evaporitic series forms the floor beds of the Triassic series and the boundary between the two systems is a distinct seismic marker. Towards the margins of the basins this marker becomes more indistinct due to facies changes in the Zechstein deposits e.g. disappearance of halite. In well sections the boundary is based on the relative increase of anhydrite in the Zechstein which can be seen on the wire line logs. The lower boundary is therefore defined purely on lithological criteria in accordance with common practice elsewhere in Northwest Europe.

Outside the areas mentioned above, Triassic rocks can rest unconformably on Lower Paleozoic sediments (mainly Silurian shales) or they overlap directly onto the Precambrian basement. This is demonstrated in the western part of Skåne (Sweden) in the Fennoscandian Border Zone (Erdmann 1872, Norling 1976 \& 1977, Bjelm et al. 1977) and in a few wells (Grindsted 1, Glamsbjerg 1, Skagen 2, Frederikshavn 1) situated in structural high areas (Sorgenfrei \& Buch 1964).

In other areas the Triassic series covers Lower Permian (Rotliegendes) volcanoclastic or arenaceous deposits as demonstrated in the $\mathrm{R}-1$ well in the northern part of the Horns Trough (cp. Michelsen 1976).

In some limited areas along the southern flank of the Ringkøbing - Fyn High the Triassic series may probably rest on Devonian or Lower Carboniferous marginal deposits, deposits which are absent in the Danish Subbasin due to post Caledonian uplift (Ziegler 1977).

\section{Distribution and thickness}

The present day distribution and thickness of the Triassic is shown on the map fig. 3 (in sep. pocket). The map is based partly on seismics, partly on limited well control (table 11). Major depocentres are situated in the northern part of Jylland within the main area of halokinesis of the Zechstein salt. Locally the total thickness of the Triassic may exceed $5000 \mathrm{~m}$ as evidenced by reflection seismic lines. The unusually great thickness is partly due to local salt withdrawal (rim synclines) accompanying the formation of the first salt pillows in late Triassic time, partly due to a high rate of subsidence in combination with fault movements centrally in the basin.

Also in the Kattegat area, NW of Sjælland in the Sejerø Bay, an important Triassic depocenter with more than $4000 \mathrm{~m}$ of sediments has been found by means of reflection seismics (fig. 4). The evolution of this center seems neither related to major fault events nor to salt withdrawal processes, but is instead characterized by even growth, somewhat accentuated in the late Triassic.

Thick deposits - more than $2000 \mathrm{~m}$ - are also found or expected in some of the north-south trending grabens or troughs intersecting the Ringkøbing Fyn High, e.g. the Horns Trough (fig. 5), some of which were deepened rapidly during the early Triassic rifting stage (Ziegler 1977).

The sediment thickness of the Triassic thins from the center of the Danish Subbasin over the Ringkøbing - Fyn High, the western blocks of which probably remained positive during most of the Triassic period. Other areas were inundated during the Mid -Triassic, e.g. the central part of Fyn as indicated by the Glamsbjerg 1 well profile.

South of the Ringkøbing - Fyn High a gradual thickening into the North German Basin is evidenced by seismic data and well control.

In the Øresund region, including the SW part of the Swedish province Skane, a general thinning of the deposits is also noticed. Further towards the southeast a thickening marks the NW extension of the 


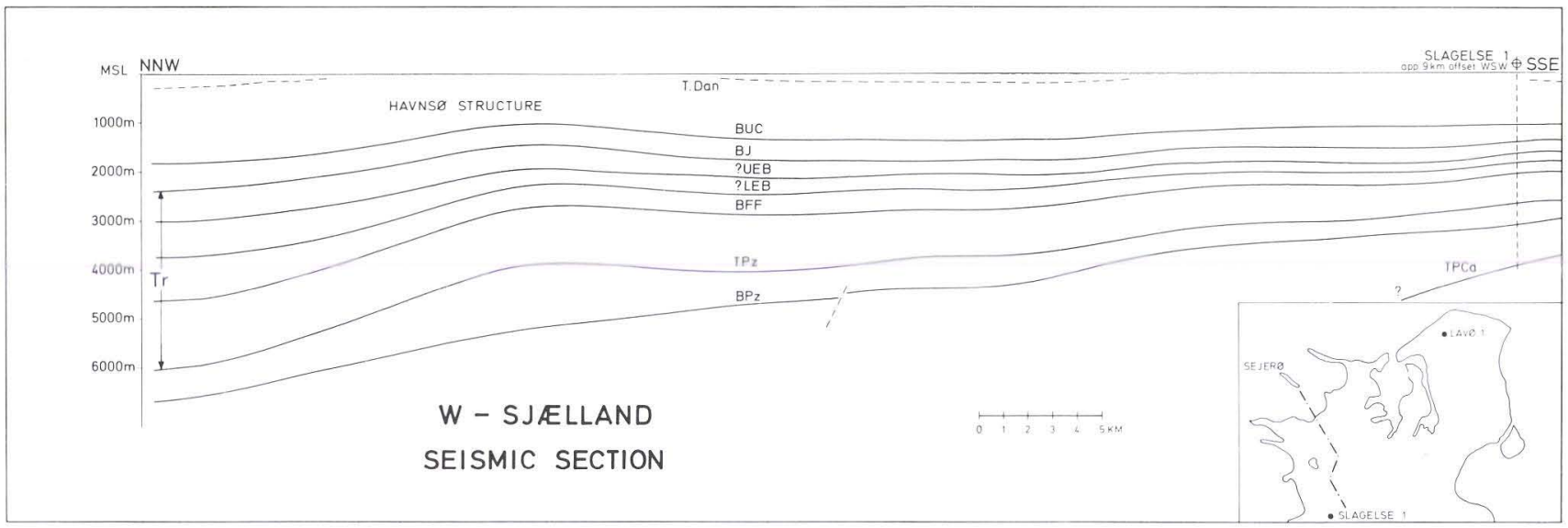

Fig. 4. NNW-SSE seismically based cross-section of western Sjælland and the Sejerø Bay. Note the increasing Triassic thickness towards the "Sejerø Bay depocenter" to the northwest. T Dan = top Danian Limestone; BUC = base Upper Cretaceous; BJ = base Jurassic (or top Gassum F.); UEB = Upper Evaporitic Beds of the Oddesund Formation; LEB = Lower Evaporitic Beds of the Oddesund Formation; BFF = base Falster Formation ("Muschelkalk"); TPz = top Zechstein; BPz = base Zechstein; TPCa = top PreCambrium; Tr $=$ Triassic. After profile prepared by C. Andersen et al. (DGU).

Polish Basin in which the maximum thickness exceeds 2000 m (Czerminskiego \& Pajchlowej 1975).

In Skåne as well as in the Kattegat area to the northwest the thinning of the Triassic across the Fennoscandian Border Zone is stepwise due to synsedimentary blockfaulting followed by differentiated subsidence and antithetic rotation of the elongated blocks forming the substratum (Bjelm et al. 1977, Norling 1977). The youngest Swedish Triassic deposits, Kågeröd Beds, Vallåkra Beds and the Mine Beds, all of which are exposed in natural outcrops or clay quarries, have in Skåne a wider lateral extension than that of the early - middle Triassic series (Norling 1977). The older deposits are limited to the east mainly by the Romele fault zone (Brotzen 1950, Norling 1977, Bjelm et al. 1977).

On the island of Bornholm, in the Baltic Sea, only "Keuper" deposits have been proven. They are visible in a minor coastal outcrop between Læså and Risbæk, but are also known from shallow wells (Gry 1969, Christensen 1972).

In the northernmost wells of Jylland, the Frederikshavn and Skagen wells, rather thin Triassic deposits were penetrated (Sorgenfrei \& Buch 1964). In the Skagen 2 well Precambrian basement granites were reached below arkosic rocks recently dated by palynology as being late Triassic in age (Bertelsen 1978).

The Triassic wedges out north and northeast of Skagen, below the Jurassic in the Kattegat (fig. 6). Floden (1973) suggested that the Triassic in this area underlies the Quaternary deposits in a rim zone more or less parallel to the present day Swedish coast. Early Tertiary Laramide uplift of the Fennoscandian
Shield (Ziegler 1977) and later glacial erosion may explain the truncation. Reflection seismic data show the same type of truncation and wedging out of the Triassic series to occur towards the Norwegian Skagerrak coast within Norwegian waters.

Sparse well data (NPD well data sheets) seem to indicate a thinning in the Norwegian - Danish Basin towards the north-western close off, and areas with more than $2000 \mathrm{~m}$ of sedimentation are probably more or less confined to the Danish part of the basin.

It should also be mentioned, that in the northern part of the Oslo Graben area a restricted occurrence of aeolian, cross-bedded sand, the Brumunddal Sandstone, has recently been suggested to be of early Triassic age (Ramberg \& Spjeldnæs 1978). If the age of the (unfossiliferous) sandstone is correctly interpreted the sandstone resting on deeply weathered Permian rhomb porphyry lavas indicates some continued subsidence of the Oslo Graben in the Triassic. It may also mean, that the early Triassic area of sedimentation was much larger than shown on the map fig. 8 .

The distribution and thickness variation of the Triassic series, as described above, demonstrates that the sedimentation followed a pattern which was already in existence during the previous Zechstein period. The Zechstein evaporite series occurs in two separate basins, the Norwegian - Danish Basin and the North German Basin, both being parts of east west trending megabasins (Ziegler 1977) separated by the Ringkøbing - Fyn High - Mid North Sea High trend. The series also extends into or through the Central Graben and into some of the north - south trending troughs intersecting the Ringkøbing - Fyn 
INE 12 -5100a $\sqrt{2}$

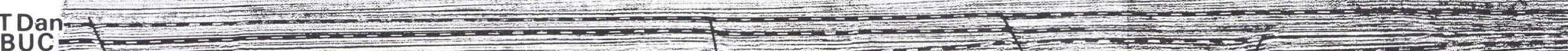

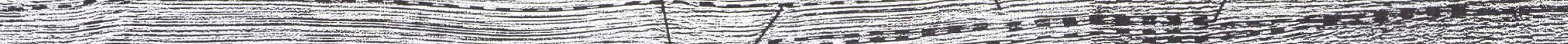

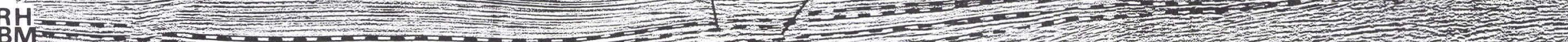

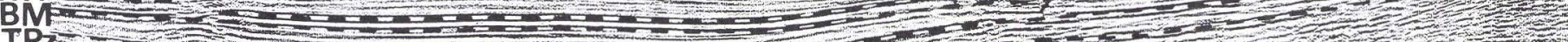

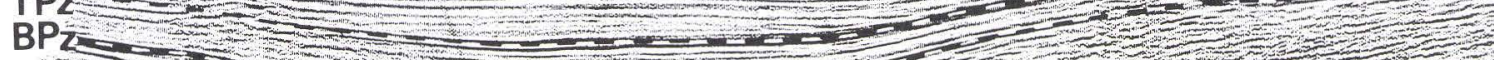

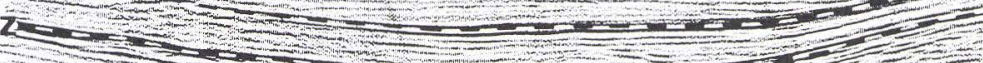

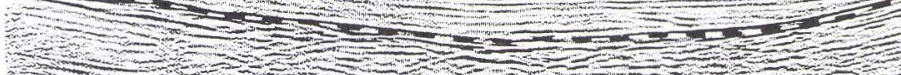
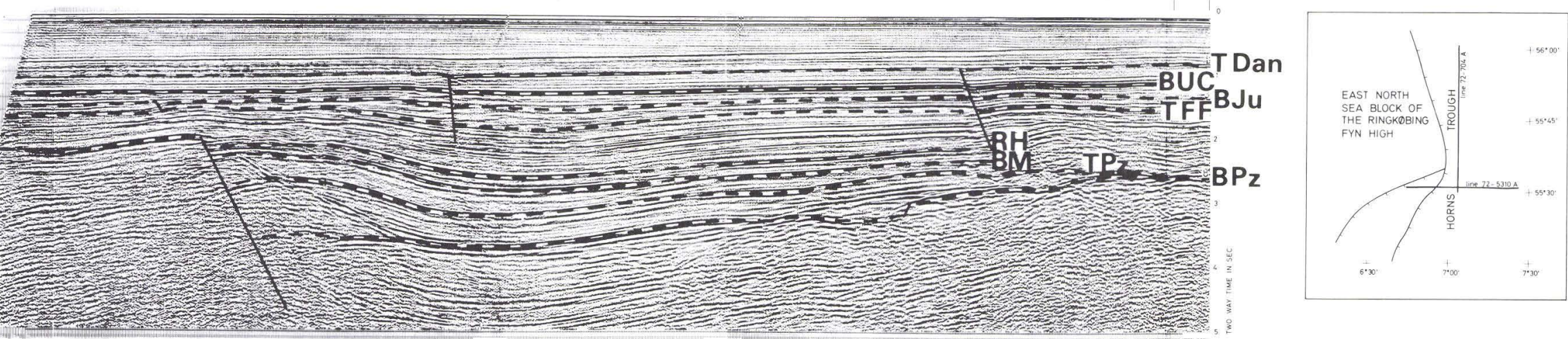

Fig. 5. Seismic sections of the Horns Trough. $\mathrm{T}$ Dan $=$ top Danian Limestone; BUC = base Upper Cretaceous; BJu = base Upper Jurassic/Lower Cretaceous (major unconformity); TFF = ?top Falster Formation ("Muschelkalk"); RH = ?Röt Halite marker. BM = "Bunter" marker (?Hardegsen Unconformity); $\mathrm{TPz}=$ top Zechstein; $\mathrm{BPz}=$ base Zechstein. Note the extension of the depositional area during the Muschelkalk transgression (lower figure, left side and upper figure, right side). After interpretation by L. Madsen (DGU). 
SKAGERRAK

SEISMIC SECTION

Line $73 \mathrm{M}$

SW

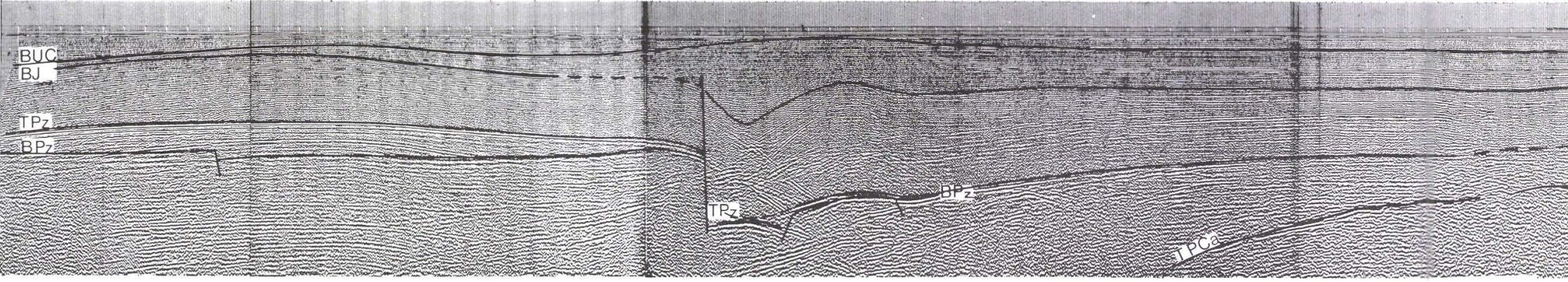

$B$ Fierritslev Fault

$\frac{k M}{i 23}$

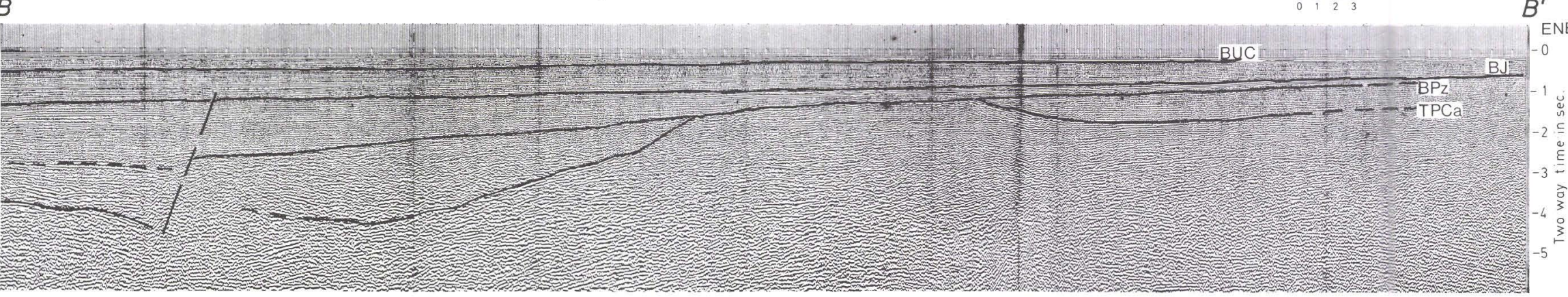

Fig. 6. Seismic section from Skagerrak. BUC = base Upper Cretaceous; BJ = base Jurassic (= top Gassum Formation); TPz $=$ top Zechstein; BPz $=$ base Zechstein; TPCa $=$ top PreCambrium. Note the formation of a Triassic depocenter on the downthrown side of the Fjerritslev Fault (cp. fig. 3) Laramide inversion (uplift) along the fault is also demonstrated by the upwards curving BUC immediately NE of the fault trend. The gradual thinning of the Triassic towards the basin margin to the northeast is demonstrated in section B - B'. After interpretation by J. C. Baartman (DGU). 
High thus indicating the outline of the submerged areas. The Danish Subbasin was most probably not connected to the SE by a so-called Polish - Danish Trough to the Polish Basin. A barrier including the Stevns Block of eastern Sjælland and the Swedish Skurup Platform seems to have separated the two basins. If a direct connection has existed, it was probably in the area of present day Storebælt sound, through the so-called Storebælt Gate (Bertelsen 1978).

\section{The cover beds}

In major parts of the Norwegian - Danish Basin and the North German Basin, the Triassic series is more or less conformably overlain by Lower Jurassic basinal claystones (Fjerritslev Formation or equivalent German formation) or marginal fluvio-deltaic arenaceous deposits (Gassum Formation) (Bertelsen 1978).

The Ringkøbing - Fyn High and a wide area of the offshore western region were uplifted by Mid-Cimmerian movements and exposed to mid - late Jurassic erosion (Bertelsen 1978). In this region Upper Jurassic or Lower Cretaceous marine beds rest unconformably on late Triassic series. It is for instance found, that away from the central part of the Ringkøbing - Fyn High the Lower Cretaceous truncates successively younger Triassic deposits: "Muschelkalk" in Glamsbjerg 1, "Steinmergelkeuper Lower Rhaetic" grey calcareous claystones in Ringe 1 and Harte 2, and "Middle" to "Upper Rhaetic" sandstones (Gassum Formation) in Ullerslev 1.

Along the northern and eastern margins of the Norwegian - Danish Basin the cover beds are Lower Jurassic sandy deposits (Gassum Formation) and/or glacial drift as discussed earlier.

The Triassic deposits found in the northwestern part of Skåne (Sweden) are either exposed or covered by thin, glacial drift or by younger Mesozoic deposits (Jurassic) (Norling 1977). This unusual present day position compared with the depth of burial of the corresponding beds in the eastern Sjælland is explained by Ziegler (1977) as late Cretaceous - early Tertiary inversion (uplift) movements along the Fennoscandian Border Zone. Similar inversions are seen in the Polish Basin and in the G.D.R. south of Rügen (Dadlez 1974, Diener 1967, Ziegler 1977).

In the Baltic Sea area southeast of the island of Bornholm early Triassic deposits may be found present below an arenaceous Upper Cretaceous lime- stone mixed facies (cp. Triassic extension by Dadlez 1974).

In general the thickest sediment cover over the Triassic series is present in the northern Jylland Mesozoic depocenter (cf. maps in Michelsen 1978) and in the Central Graben with major late Jurassic Tertiary overburden (cf. cross section in Ziegler 1977). The Horns Trough was filled chiefly during the Triassic and the cover consists of mainly Upper Cretaceous and Tertiary series. The fill of the Rønne Graben is unproven by drilling.

\section{Lithostratigraphical subdivision}

Three facies provinces are recognized within the studied area:

1. The Germano-type Facies Province comprising the northern part of the North German Basin, the Ringkøbing-Fyn High trend, and the central and southern part of the Danish Subbasin.

2. The Northern Marginal Facies Province covering the zone of marginal deposition along the Fennoscandian Border Zone and the northern and western part of the Danish Subbasin.

3. The Central Graben Facies Province forming a northern outlier of the Southern North Sea Basin facies regime.

In the Germano-type Facies Province the depositional pattern is readily comparable with that of the North German Basin and the Polish Basin. Four major phases in the basin development are recognized: a regressive phase ("Lower - Middle Buntsandstein"), a transgressive phase ("Röt - Muschelkalk"), a regressive phase ("Lower - Middle Keuper") and a transgressive phase ("RhaetKeuper"). The deposits of each major phase are proposed ranked as a group, and within each group two formations are recognized:

Mors Group (new):

Gassum Formation (Larsen 1966, Bertelsen 1978)

Vinding Formation (Larsen 1966, Bertelsen 1978)

Jylland Group (new):

Oddesund Formation (new)

Tønder Formation (new)

Lolland Group (new):

Falster Formation (new)

Ørslev Formation (new) 
TRIASSIC LITHOSTRATIGRAPHIC NOMENCLATURE OF DENMARK

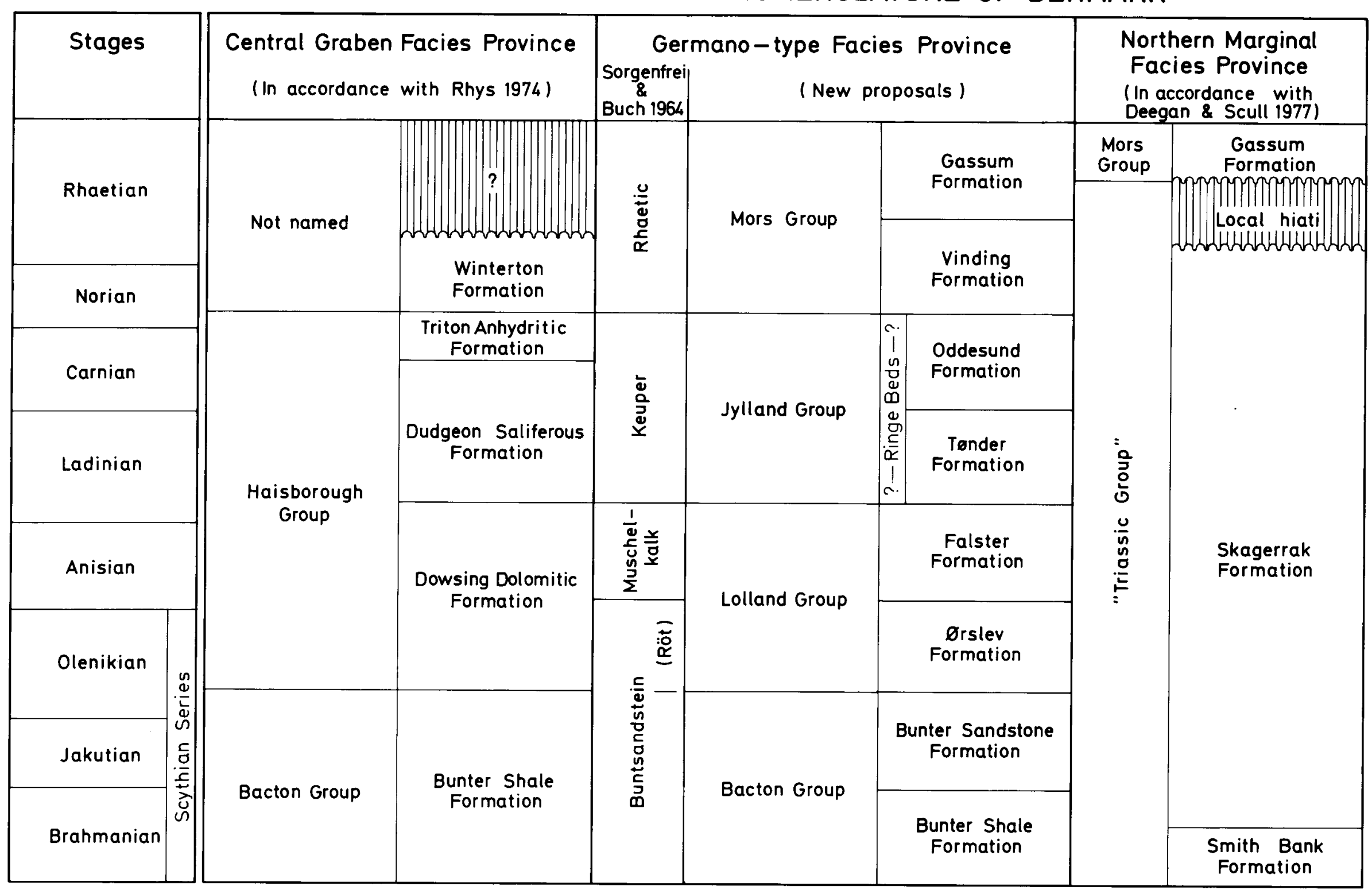

Fig. 7. Schematic illustration of the relationship between the Danish Triassic lithostratigraphical units as proposed in the present paper. 
Bacton Group (Rhys 1974):

Bunter Sandstone Formation (Rhys 1974)

Bunter Shale Formation (Rhys 1974)

In the Northern Marginal Facies Province the following nomenclature is proposed:

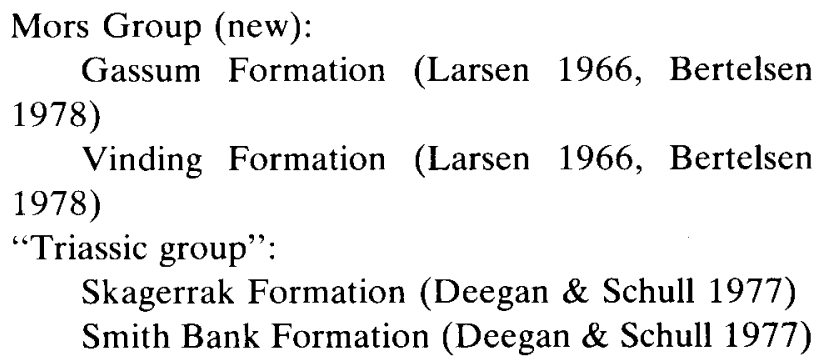

Gassum Formation (Larsen 1966, Bertelsen 1978)

Vinding Formation (Larsen 1966, Bertelsen

"Triassic group":

Skagerrak Formation (Deegan \& Schull 1977)

Smith Bank Formation (Deegan \& Schull 1977)

The monotonous "Triassic group" is thought chronostratigraphically - to correspond to the three oldest groups of the Germano-type Facies Province.

In the Central Graben Facies Province the lithological development is closely comparable to that of the Southern North Sea Basin, except that low sand content in the Bacton Group does not permit the separation of the Bunter Sandstone. The nomenclature proposed by Rhys (1974) is fully adopted:

No group designation:

Winterton Formation (Rhys 1974)

Haisborough Group (Rhys 1974):

Triton Anhydritic Formation (Rhys 1974)

Dudgeon Saliferous Formation (Rhys 1974)

Dowsing Dolomitic Formation (Rhys 1974)

Bacton Group (Rhys 1974):

(Bunter Sandstone Formation) (Rhys 1974)

Bunter Shale Formation (Rhys 1974)

The relationship between the individual units is shown in fig. 7 . In the following the stratigraphical subdivision and basin development of each of the three facies provinces is described. Greatest importance is attached to the description of the Germano-type Facies Province, because this province occupies the main area of the territory, shows the most diversified lithologies and is reasonably covered by well control points. Further scattered well information is at present being released for the Central Graben. For each of the four groups proposed in the Germano-type Facies Province an isopach map has been constructed. Because this facies province to the northwest grades into the Northern Marginal Facies Province the isopach contours of the maps are continued into the area of the latter province. The transitional zone is indicated by the $50 \%$ sand line on fig.
8 or by a 'facies change line' (figs. 11,15). In the Central Graben the names and thicknesses of the group equivalent beds are drawn as well. For comparison the corresponding German, Polish and Swedish nomenclature is also given on the maps. It must be stressed, that the maps are constructed as models and not as fact sheets, due to the scarce well and seismic control in the major part of the studied region.

\section{The Germano-type Facies Province}

\section{Bacton Group Rhys 1974}

The Bacton Group was defined by Rhys 1974 for the sequence of clastic red beds with relatively low content of anhydrite and carbonate, forming the lowermost unit of the Triassic series in the Southern North Sea Basin. The group consists of a lower pelitic formation, the Bunter Shale, and an upper arenaceous formation, the Bunter Sandstone. For reasons mentioned in the description of the formations, the nomenclature of Rhys has been adopted in the Danish area in preference to the hitherto used German one.

The group boundaries are well defined, as the Bacton Group overlies and is overlain by evaporite sequences.

The deposits of the Bacton Group form the first, regressive megaphase of the Triassic. The boreal influence on the sedimentary basins which prevailed during the late Permian came to an end and connections to the southern Tethys were not yet established.

The extension and the thickness of the Bacton Group within the Danish area is shown on the map, fig. 8 .

\section{Bunter Shale Formation Rhys 1974}

Type section. (Rhys 1974, fig. 4). Conoco Group 49/21-2 well, U.K. North Sea sector

$53^{\circ} 19^{\prime} 00^{\prime \prime} \mathrm{N}-02^{\circ} 05^{\prime} 45^{\prime \prime} \mathrm{E}$

Depth interval

$1664 \mathrm{~m}-1979 \mathrm{~m}$ below M.S.L.

$5563^{\prime}-6597^{\prime}$ below K.B.

$(\mathrm{GR}+\mathrm{ITT} / \mathrm{GR}+\mathrm{ITT})$

Thickness in type section: $315 \mathrm{~m}$ 


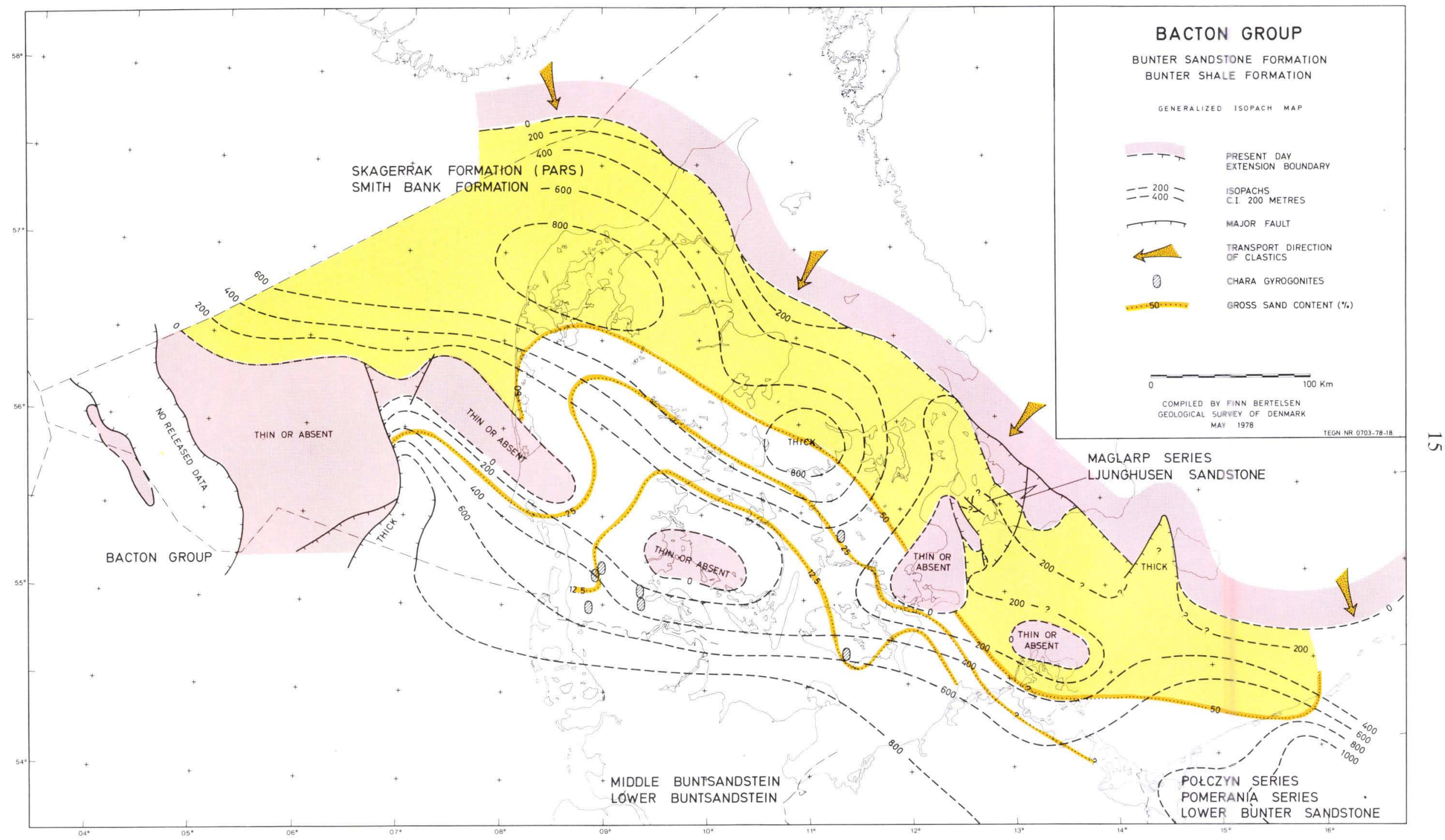

Fig. 8. Bacton Group isopach map. Compiled from well data and sources mentioned in the selected bibliography. 
Reference section. (fig. 9). Ørslev 1 well, DGU File No. 238.502

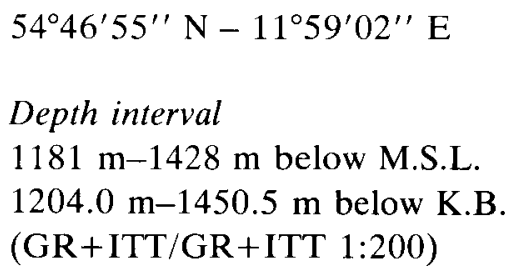

Thickness in reference section: $247 \mathrm{~m}$

Remarks. The unit was formally originated by Rhys (1974) for the series earlier designated as the Lower Bunter (Buntsandstein) in the Southern North Sea Basin. The lowermost Triassic beds recorded in wells in southern and central Denmark show the same lithology and log motifs as the Bunter Shale Formation of Rhys (1974), thus the term is proposed introduced in the Danish lithostratigraphic nomenclature. General remarks on the naming of the Triassic lithostratigraphical units in the Southern North Sea are given on p. 43.

\section{Description}

\section{Lateral extension and thickness}

The general thickness recorded in wells is $200-300 \mathrm{~m}$ (cf. table 1). A much greater thickness has been drilled in the southern part of the Danish Central Graben (more than $1000 \mathrm{~m}$ ), but unfortunately the well data is still to be released. The formation constitutes the northern wedge-like part of a large scale lenticular body occupying the southern west-east trending Permo-Triassic megabasin composed of the Southern North Sea Basin, the North German Basin and the Polish Basin. Regional thinning and local areas of non deposition are noticed over the Ringkøbing-Fyn High trend, while in the Norwegian - Danish Basin the formation is developed in the southern part (e.g. Dansk Nordsø C-1, Nøvling 1, Slagelse 1). In the central and the northwestern part of the basin the formation seems to continue in the basal argillaceous Triassic sequence here known as the Smith Bank Formation (Deegan \& Scull 1977), which is discussed later. In general, however, the formation is replaced laterally towards the margin of the basin by arenaceous beds known as the Skagerrak Formation (Deegan \& Scull 1977), or the Maglarp series in Skåne (Sweden) as named in Bjelm et. al. (1977). The map fig. 8 shows the composite isopach map of the Bunter Shale Formation and the overlying Bunter Sandstone Formation.

\section{Lithology}

The formation is a rather uniform series of red-brown to brown with greenish spots, silty, non-calcareous to highly calcareous or dolomitic, micaceous claystones, with interbedded minor siltstone or, greyish, greenish or reddish, generally calcareous and micaceous fine-grained sand. Lumps, nodules and irregular stringers of white, reddish, greenish or transparent anhydrite, occur throughout the formation. Thin beds of dolomite are locally present. Salt crystals have been observed in a core from the Tønder 1 well.

In the southeastern part of the study area represented by the wells Rødby $1 \& 2$, Ørslev 1 and Slagelse 1(?) there occur some 6-7 bands of, red-brown, argillaceous and arenaceous oolitic limestone in the upper part of the formation (see ref. section, fig. 9).

The transitional beds to the underlying Zechstein evaporitic series are characterized by an increased content of anhydrite. In the Ringe 1 well, where no Zechstein evaporites are present, a basal sandy unit has been drilled.

The sedimentary structures are less well-known. Limited information from minor cored sections in the wells Arnum 1, Tønder 1, Ringe 1 and Rødby 1, indicates laminated bedding, but cross-bedding may occur (Rødby 1).

\section{Log motifs and boundary definitions}

The formation is characterized by very uniform log motifs (see pls. $1 \& 2$ ). The gamma ray and the interval transit time (ITT) logs show finely serrated log motifs reflecting the laminated sequence of clay/siltstone. The above-mentioned oolitic limestones in the Rødby and Ørslev wells are seen as distinct peaks at the gamma ray log, the ITT log and the resistivity logs.

The lower boundary is mostly distinct and is set at the top of the uppermost massive Zechstein anhydrite bed, which is easily recognized on the resistivity $\log$, the formation density log or on other adequate logs.

The upper boundary is placed at the base of the overlying basal sandstone member of the Bunter Sandstone Formation by means of a gamma ray interval transit time or SP - resistivity log. The boundary between the two formations is generally well-defined and distinct.

\section{Subdivision}

The formation is not subdivided. The oolitic limestone bearing beds occuring in the Rødby and Ørslev wells may be compared with similar beds in the 


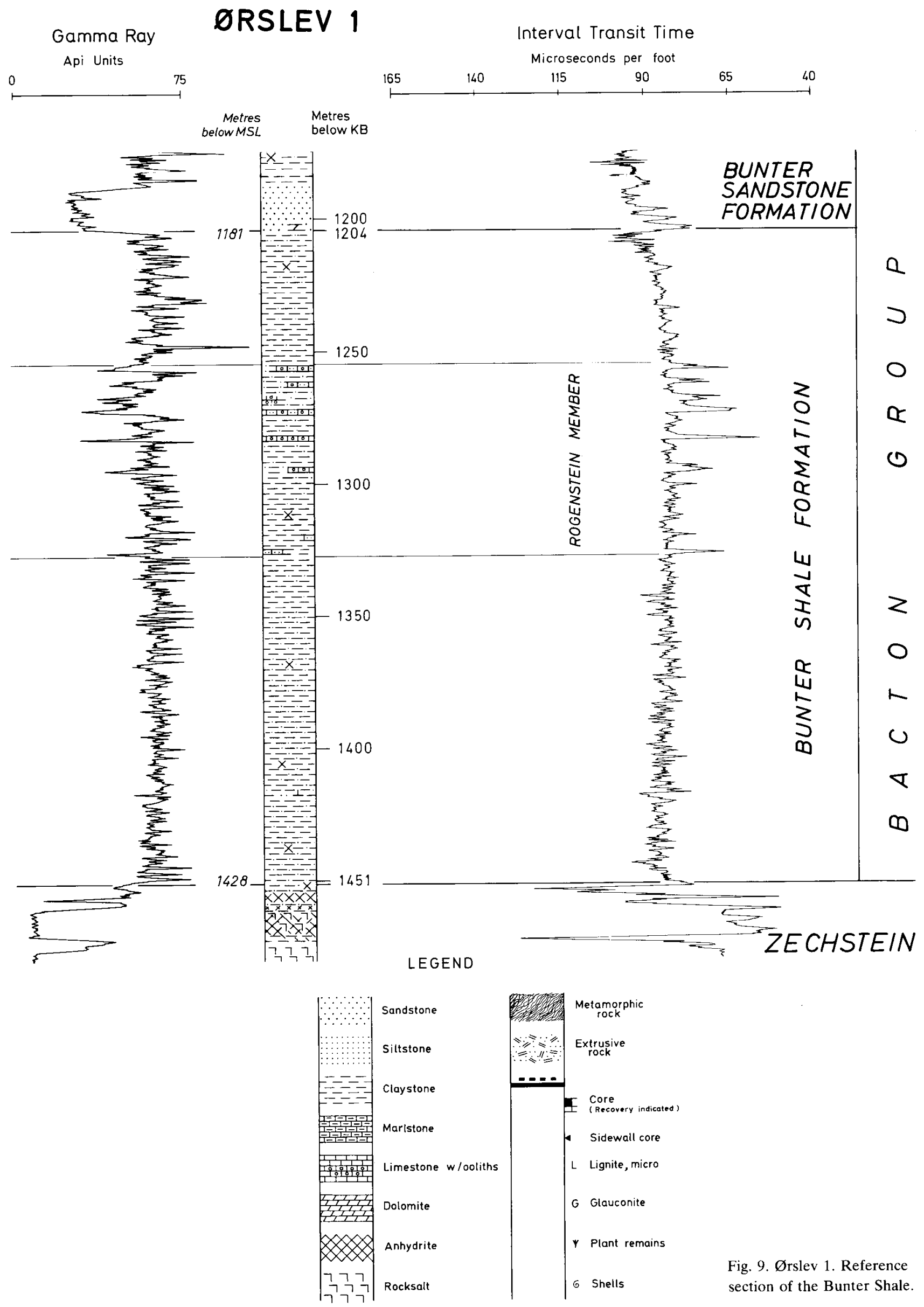


southern megabasin commonly known as Rogenstein, a German term. Rhys (1974) adopted the term and recognized the unit as the Rogenstein Member in the Southern North Sea Basin. A recognition of a basal arenaceous/evaporite-rich unit corresponding to the Bröckelschiefer (cp. Rhys 1974, Brennand 1975, Hoppe 1976) is probably not possible in the majority of the Danish wells, therefore this term is not introduced in the area of study.

\section{Geological age}

No fossils have so far been recovered from the Danish Bunter Shale, but only a small part of the core material has been studied palynologically.

In the North German Basin the first Triassic fossils appear in the $\mathrm{su}_{2}$ of the 'Unteren Buntsandstein', that is in the sequence overlying the basal 'Bröckelshiefer' (Kozur 1975). According to Kozur (loc. cit.) the 'Unteren Buntsandstein' may be correlated with the Brahmanian Stage of the Scythian Series. Brennand (1975) mentions, that "there is some slender evidence for a lowermost Scythian age in the Bröckelschiefer of the West Sole gas-field and in wells of the quadrant 38 area". Fuglewicz (1977 a, b) describes megaspores of the Lower Buntsandstein of Poland, but the stratigraphical importance of this discovery is not yet evaluated. Palynological investigations of the Permo-Triassic transitional beds in eastern England (Pattison et al. 1973) have shown the lowermost beds assigned to the Triassic to be palynologically barren.

If the Danish deposits are considered more or less isochronous with the equivalent beds in the southern megabasin, they may be correlated with the early Scythian, but the age assignment is rather speculative. In this connection it is also important to refer to the concepts of diachronism of the lithological boundary between the Zechstein and the Bunter as discussed in Visscher (1971).

\section{Interpretation of depositional history}

The sedimentary conditions which existed in the Danish area during the deposition of the Bunter Shale are probably best understood and interpreted if a comparison is made with the homologous deposits in the southern megabasin, where numerous boreholes and natural outcrops permit a much more far-reaching evaluation than the one, which may be deduced from the meagre Danish data alone.

The Bunter Shale of the Northwesteuropean epicontinental basins represents a regressive phase during which the marine Zechstein conditions were replaced by mainly continental environments. As dis- cussed by Pattison et al. (1973) and Brennand (1975), this transition most probably took place during relative stable tectonic conditions. The anhydrite bearing pelitic red bed sequences which are typical for the formation seem to indicate prevailing hypersaline, low energy deposition, probably initially related to large-scaled coastal plain sabkhas (un-fossiliferous), later to ephemeral lakes and inland sabkhas (cp. Kendall 1978).

The occurrence of ooliths in various horizons throughout the central part of the southern megabasin known as the Rogenstein (Rusitzka 1967, Brennand 1975, Senkowiczowa \& Szyperko-Sliwczynska 1975, Hoppe 1976) bears witness of shallow water conditions in the basin center probably related to short-lived marine ingressions (cp. discussion in Hoppe 1976).

The appearance of ostracods of Darwinula type and megaspores in the German and Polish basins indicate that periods of more permanent brackish to freshwater conditions may have occurred in these areas (Kozur 1976, Fuglewicz 1977 a, b).

The climatic conditions can be deduced from the sediment characteristics of red colouring and anhydrite occurrence. According to Walker $(1967,1974)$ the formation of red beds may take place in both hot-dry and hot-moist tropical environments as a result of postsedimentary diagenetic intrastratal processes, which allow formation and preservation of iron oxides. In conclusion Walker (1976, loc. cit.) stated, that "the results of this study support the belief that the red beds per se are not reliable indicators of the climate either in the source area or in the depositional basin". Walker (1967, loc. cit.) also mentioned, that an elevated temperature possibly favors the formation of hematite, which may however also form when long periods of aging are involved. The presence of evaporites throughout the Bunter Shale is therefore here taken as the main indicator of semi-arid to arid, hot climatic conditions during deposition.

If the concepts of formation of red beds by Walker are correct, the suggestion by Brennand (1975, p. 300 ) of a source area for the Bunter Shale covered by Permian deposits is not necessarily correct.

The Danish Bunter Shale of both the Germano-type Facies Province and the Central Graben Facies Province (p. 43) are here, in general, considered deposited in supratidal and continental environments, that is on a supposed extensive and flat continental plain fringing the northern margin of the southern megabasin. As mentioned in the lithological description, the oolitic deposits - the Rogenstein - are only 
recognized in the southernmost Danish wells (see also pls. $1 \& 2$ ), which means that the supposed marine ingressions only weakly affected the Danish area. Further, the Bunter Shale seems to grade into the coarser Smith Bank and Skagerrak Formations to the north, which undoubtedly indicate a northern Fennoscandian source area for the clastics. The negative results so far obtained in the search for microfossils in the well materials indicate also oxidizing, continental environments.

\section{Bunter Sandstone Formation Rhys 1974}

Type section. (Rhys 1974, fig. 4) Conoco Group 49/21-2 well, U.K. North Sea sector $53^{\circ} 19^{\prime} 00^{\prime \prime} \mathrm{N}-02^{\circ} 05^{\prime} 45^{\prime \prime} \mathrm{E}$

\author{
Depth interval \\ $1344 \mathrm{~m}-1664 \mathrm{~m}$ below M.S.L. \\ $4512^{\prime}-5563^{\prime}$ below K.B. \\ $(\mathrm{GR}+\mathrm{ITT} / \mathrm{GR}+\mathrm{ITT})$
}

Thickness in type section: $320 \mathrm{~m}$

Reference section. (fig. 10). Rødby 1 well, DGU File No. 240.75

$$
\begin{aligned}
& 54^{\circ} 41^{\prime} 37^{\prime \prime} \mathrm{N}-11^{\circ} 24^{\prime} 18^{\prime \prime} \mathrm{E} \\
& \text { Depth interval } \\
& 1125 \mathrm{~m}-1382 \mathrm{~m} \text { below M.S.L. } \\
& 3710^{\prime}-4551^{\prime} \text { below K.B. } \\
& \text { (SP+Res/SP+Res) }
\end{aligned}
$$

Thickness in reference section: $256 \mathrm{~m}$

Remarks. The formation was defined and named by Rhys (1974) for the arenaceous series hitherto described as the Middle Bunter (Buntsandstein) in the Southern North Sea Basin.

The Rødby 1 well has been preferred as reference section in favour of the more recently logged Ørslev 1 well for the following reasons: The section in Ørslev 1 seems to be incomplete compared with others of the southernmost wells. Four cores were cut in the Rødby 1 well thereby facilitating a more precise characterization of the sediments.

The upper boundary is defined somewhat differently from that of the type section. See further below under ' $\log$ motifs and boundary definitions'.
Description

Lateral extension and thickness

The general thickness of the formation is less than 300 metres (see table 2). In the southern depocentres of the Horns Trough and Central Graben (Danish sector) thicknesses of more than 1000 metres are recorded. Regional thinning and local absence over the Ringkøbing-Fyn High trend are noted. In the central part of the Danish Subbasin the Bunter Sandstone Formation coalesces with the Skagerrak Formation. To the southeast, in northern Poland, its continuation is named the Pomerania and Polczyn Series (Szyperko-Sliwczynska 1976). To the south it extends into the North German Basin. The map fig. 8 shows the composite isopach map of the Bunter Shale Formation and the Bunter Sandstone Formation.

\section{Lithology}

The formation consists of red-brown and yellow-brown, green spotted fine-grained sandstone, siltstone and claystone, which locally is highly calcareous, anhydritic, and micaceous. To the south the formation typically consists of three sandstone or siltstone members each overlain by a claystone sequence. Towards the north the uppermost sandstone members probably join into one sandy unit, which further to the north grades into part of the Skagerrak Formation. The sandstones, which are imperfectly known from less than 20 metres of cores in the southern part of the country, are in the original wellsite reports described as horizontally bedded or crossbedded, sometimes homogeneous without visible bedding planes.

\section{Log motifs and boundary definitions}

The lower boundary is defined as the base of the (lowermost) sandstone as seen on the SP or gamma ray $\log$. The upper boundary is the base of the overlying evaporites of the Ørslev Formation, which is distinctive on the resistivity logs.

The sandstone or siltstone members of the southern wells generally stand out on the wire line logs (cp. pls. $1 \& 2$ ), but in some of the wells with poor log quality the lower boundary is not always distinct.

The variable content of anhydrite or carbonate in the silt/sandstone beds generally impede the use of the SP or gamma ray logs as grain size indicators and characteristic log motifs are thus hard to define. The $\log$ motifs of the pelitic sections are similar to those of the Bunter Shale.

\section{Subdivision}

No attempt at a subdivision of the formation in the southern wells has been carried out, because a more 


\section{RØDBY 1}

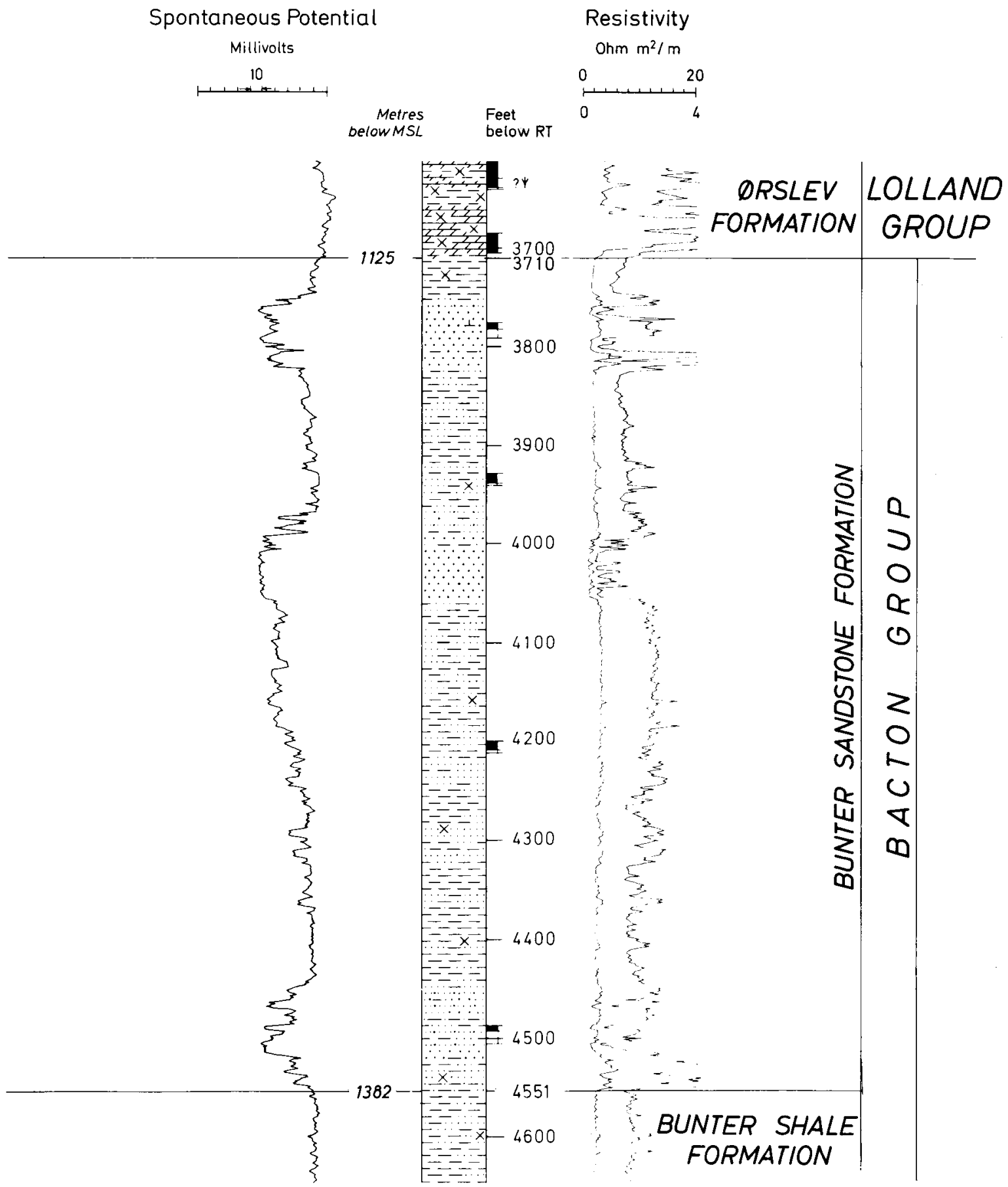

Fig. 10. Rødby 1. Reference section of the Bunter Sandstone. For Legend see fig. 9. 
detailed analysis of the existing data and materials seems necessary for a satisfactory member definition. However, such a subdivision is undoubtedly possible.

\section{Geological age}

Rich assemblages of Chara gyrogonites have been encountered in the uppermost sands of the formation in many wells situated in the southern part of Denmark (for distribution see map fig. 8). They are however still undetermined, but may prove to be useful for a correlation of the Danish deposits with the German ones, where a preliminary Chara zonation has been carried out by Kozur (1975). Kozur correlates the German Middle Buntsandstein with the Jakutian - early Olenikian stages of the Scythian Series.

\section{Interpretation of the depositional history}

In the southern megabasin the deposition of fine-clastic sediments, the Bunter Shale which is typical in the earliest Triassic phase is rather abruptly replaced by blanket type sandstone sedimentation in the middle Scythian, probably due to a combination of increased humidity and epeiric hinterland movements. In the southern part of the German area four upwards fining megacycles are recognized (Boigk 1959, 1961): the Volpriehausen, the Detfurth, the Hardegsen and the Solling "Folgen". A major unconformity - the Hardegsen Unconformity - between the latter two cycles is noticed in the German-Dutch sequence and is probably tracable even into the British area (Herman 1962, Geiger \& Hopping 1968, Brennand 1975). The previously mentioned south-central German sandstones have a southern origin (Schnitzer 1969, Hoppe 1976).

Deposition in the basin center areas is supposed to have taken place in very shallow brackish marine environments as evidenced by such features as cross-bedding, ripple marks and occassional desiccation cracks in the Helgoland sands (Wurster 1960) as well as by the occurrence of oolitic deposits (Hoppe 1976). Trace fossils such as Corophioides and Rhizocorallium (Lohmann 1960, Hoppe 1976), suggest tidal flat sedimentation. A generally low salinity of the sea is indicated by impoverished ostracod faunas of Darwinula and ? Clinocypris combined with occurrence of Chara gyrogonites (Kozur 1975, Hiltermann \& Mädler 1979).

The marginal areas of the epicontinental basin are characterized by continental, fluvio-limnic deposition with increasing coarseness of the sediments towards the source areas. Trace fossils in the form of tetrapod footprints (Lohmann 1960) are common in the German deposits. Fossil soil horizons with incrusta- tion of silica, and root layers are described by Ortlam (1969) from the Rhein valley Buntsandstein.

The climate seems gradually to have become more favorable (wet) during this phase of the basin evolution as proven by rapid development of spore plants (Orlowska-Zwolinska 1977, Fuglewicz 1973). According to Hoppe (1976) a semi-arid climate prevailed during the period. Increased humidity also explains the increased influx of coarse clastic sediments into the basin.

According to Fuglewicz (1973), Senkowiczowa \& Szyperko-Sliwzynska (1975) and Kozur (1975) the marine influence on the basin was related to boreal, northwestern connections until the so-called Röt transgression established the connection with the Tethys Sea. It is however difficult to accept a late Permian type boreal connection to the southern megabasin from the present knowledge of the Scythian facies types recognized in the North Sea area (Audley-Charles 1970, Brennand 1975, Deegan \& Scull 1977, present study). A boreal connection through the present day North Sea would have been over the Central Graben area, where no indications of such a transgression route appear to be recognizable.

In Denmark the northern margin of the basin center environmental regime may be traced into the southernmost part of the Danish Subbasin judging from the distribution and occurrence of Chara gyrogonites (see map fig. 8), whereas the remaining part has a marginal and continental character.

The sands occurring in the northern part of the North German Basin and in the Norwegian-Danish Basin undoubtedly were derived from the north and northeast. The sand/shale ratios indicated by the map fig. 8 show a decreasing sand content towards the depocenter of the North German Basin. Heavy mineral analyses by Sindowski (1957) and Larsen \& Friis (1975) on material from wells and outcrops south of the Ringkøbing-Fyn High all showed the same characteristically high content of garnet and a northern, Scandinavian origin of the Bunter clastics was proposed by the authors.

In the northern part of the Polish Basin the facies distribution within the equivalent beds, the Pomerania Series and the Polczyn Series also indicates a northern and northeastern source of the clastics (Szyperko-Sliwczynska 1976).

The sand content of the Danish southern Central Graben has hitherto been found to be very low, which is here explained as a function of the distal position of the area, far from the southernly situated source area of the Bunter Sandstone of the Southern 
North Sea Basin (Brennand 1975) and far from and ?screened from the source area of the Norwegian-Danish Basin. Local origin from the fine-grained Paleozoic sediment cover of the Mid North Sea High and the East North Sea Block of the Ringkøbing-Fyn High may also serve as an explanation for the hitherto observed absence of coarse clastics.

Recent studies by G. Pedersen (DGU) on core material of the Bunter Sandstone from the Gassum 1 well have shown that the sands were most likely deposited in a fluvial system of braided streams.

\section{Lolland Group new group}

The ?late Olenikian - Anisian - early Ladinian Ørslev and Falster Formations described below are proposed combined into the Lolland Group.

The group is composed of mixed lithologies of mainly greyish green, grey and reddish brown, anhydritic and dolomitic claystone, bedded limestone, dolomite and towards the basin center with evaporite beds of anhydrite and halite.

The lower boundary of the group with the Bacton Group is the base of the Röt Halite or equivalent anhydritic beds. The upper boundary with the Jylland Group is at the top of the greenish grey coloured, limestone bearing Falster Formation. Towards the north and east the group grades into the arenaceous Skagerrak Formation. To the south there is an increasingly marine influence of the group and the Röt and Muschelkalk Halites show maximum development in the depocenter of the North German Basin. The Dowsing Dolomitic Formation of the Haisborough Group in the Southern North Sea Basin corresponds to the Lolland Group (cp. fig. 7).

The deposits of the Lolland Group form the second transgressive megaphase during which the epicontinental, Central- and Northeuropean Triassic area was connected with the Tethys Sea.

The extension and thickness of the Lolland Group is shown at the map fig. 11 .

Type sections of the two formations are defined in wells situated on the southeastern Danish islands. Hence the group is named after one of these, the island of Lolland (see fig. 1).

\section{Ørslev Formation new formation}

Type section. (fig. 12). Ørslev 1 well, DGU File No. 238.502

\author{
$54^{\circ} 46^{\prime} 55^{\prime \prime} \mathrm{N}-11^{\circ} 59^{\prime} 02^{\prime \prime} \mathrm{E}$ \\ Depth interval \\ $958 \mathrm{~m}-1064 \mathrm{~m}$ below M.S.L. \\ $980.6 \mathrm{~m}-1087.0 \mathrm{~m}$ below K.B. \\ $(\mathrm{GR}+\mathrm{ITT} / \mathrm{GR}+\mathrm{ITT} 1: 200)$
}

Thickness in type section: $106 \mathrm{~m}$

Reference section. (plate 1). Rødby 1 well, DGU File No. 240.75

$$
\begin{aligned}
& 54^{\circ} 41^{\prime} 37^{\prime \prime} \mathrm{N}-11^{\circ} 24^{\prime} 18^{\prime \prime} \mathrm{E} \\
& \text { Depth interval } \\
& 965 \mathrm{~m}-1125 \mathrm{~m} \text { below M.S.L. } \\
& 3185^{\prime}-3710^{\prime} \text { below K.B. } \\
& (\mathrm{SP}+\mathrm{Res} / \mathrm{SP}+\mathrm{Res} 1: 500)
\end{aligned}
$$

Thickness in reference section: $160 \mathrm{~m}$

Derivation of name. The formation is named after the type locality well.

Remarks. The name Ørslev Formation is introduced for the rock unit formerly referred to as the Röt, which is a German term. As the term Röt has been used and is still used in both a lithostratigraphical and a chronostratigraphical sense in the southern megabasin by various authors, it has been decided to avoid future confusion - at least in the Danish area by the proposal of a pure lithostratigraphical, local term.

\section{Description}

\section{Lateral extension and thickness}

The lateral extension is shown on the map fig. 11. The formation thins or is absent over part of the Ringkøbing - Fyn High and noteworthily, also in the northern part of the Horns Trough (fig. 5). Equivalent deposits are present in the southern part of the Danish Central Graben, where they are included in the Dowsing Dolomitic Formation (see p. 43). How far north the deposits in this region extend is not yet clarified. In the Danish Subbasin the Ørslev Formation probably grades (laterally) into part of the Skagerrak Formation. Transitional beds seem to be present in the wells Rønde 1 , Gassum 1 and Mors 1. In onshore wells the general thickness of the formation is $100-200 \mathrm{~m}$ (table 3 ). 


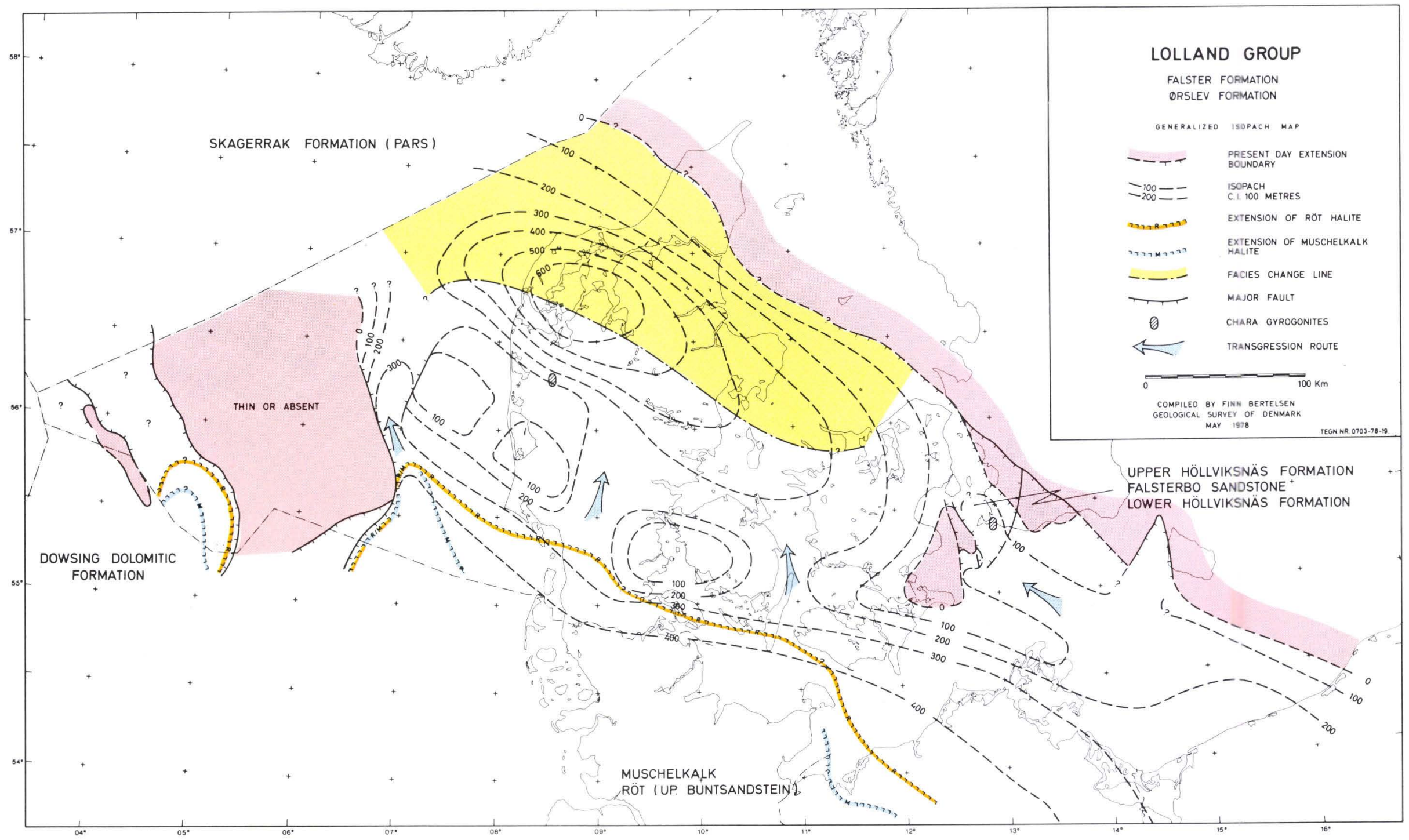

Fig. 11. Lolland Group isopach map. Compiled from well data and sources mentioned in the selected bibliography. 


\section{ØRSLEV 1}

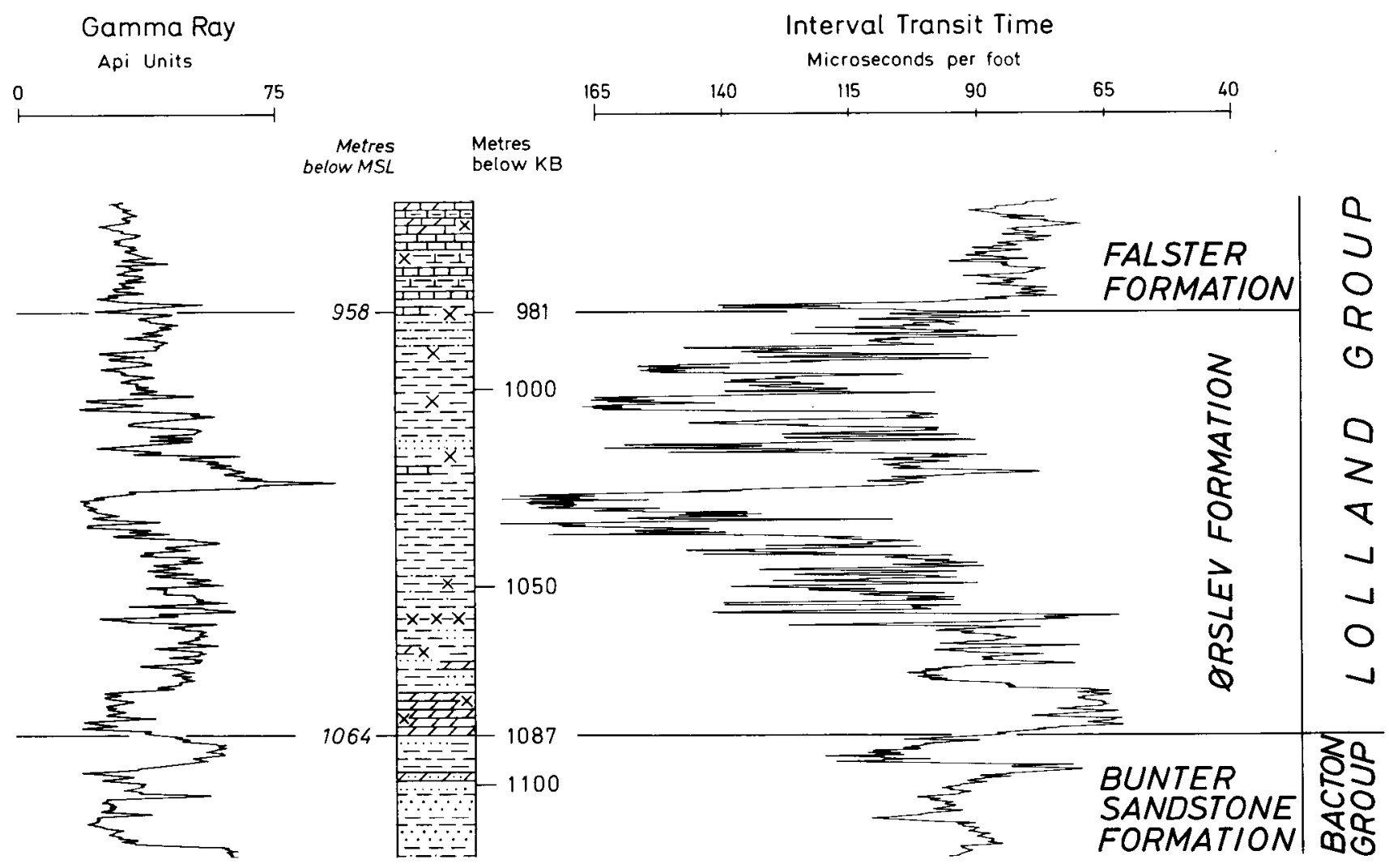

Fig. 12. Ørslev 1. Type section of the Ørslev Formation. For Legend see fig. 9.

\section{Lithology}

The formation is bipartite with a basal evaporite member which is overlain by a claystone member. In the southernmost part of the country, in the southern part of the Horns Trough and in the Central Graben the evaporite member consists of halite, anhydrite and interbedded, mainly red-brown and grey, calcareous claystone. Further north the evaporite member grades into a facies of light grey-green and brownish, mainly dolomitic limestone, interbedded with greenish grey and red-brown claystone and marlstone, with some anhydritic inclusions. The upper part of the formation is composed of silty, red-brown to dark brown calcareous claystone with greenish grey spots, and with the occurrence throughout of anhydrite inclusions. Some minor interbeds of greenish grey and commonly calcareous siltstone, also occur, especially just above the lower evaporitic beds.

\section{Log motifs and boundary definitions}

The lower boundary is defined as the base of the evaporite member, which is marked by increased resistivity and density due to anhydrite or dolomite (see pls. $1 \& 2$ ). The upper boundary is set at the base of the first limestone bed of the overlying Falster Formation at the top of the uniform upper claystone member. This boundary is commonly marked by a distinct colour change from greenish grey above to red-brown below. The log motifs show very high resistivity in the evaporitic beds and increased resistivity in the lower part of the overlying claystone. The complicated mixed lithology of the evaporitic/dolomitic beds is best interpreted in modern wells where adequate logs permit the use of various cross-plotting techniques.

\section{Subdivision}

A formal subdivision of the Ørslev Formation into members has not yet been carried out, because more investigations are necessary for the final proposals. It is, however, obvious that at least two members may be defined, one for the lower evaporitic beds and one for the upper, pelitic beds.

\section{Geological age}

No biostratigraphical data are at present available from the Ørslev Formation, but the formation is 
considered more or less contemporaneous with the Röt deposits of Poland and Germany, the age of which may be referred to the late Olenikian - early Anisian based on the investigations of Kozur (1975) and Orlowska-Zwolinska (1977). Kozur (1975) correlates the German Röt with the uppermost Olenikian to basal Anisian. In his opinion the Scythian is to be regarded as a series composed of three stages, the Brahmanian, the Jakutian and the Olenikian. Orlowska-Zwolinska (1977) refers the Polish Röt to the late Scythian on the basis of palynological investigations. The assemblages are found to be distinctly different from those of the Bunter Sandstone, but they compare well with those of the Polish Lower Muschelkalk.

\section{Interpretation of the depositional history}

In the southern megabasin the so-called Röt deposits represent a transgressive stage in the Triassic development. Connection to the southern Tethys sea was established through the Silesian-Moravian Gate and through the Polish East Carpathian Gate (cp. fig. 14), which allowed an Alpine faune to immigrate into the epicontinental area (Senkowiczowa \& Szyperko-Sliwczynska 1975). The composition of the fauna is summarized in Senkowiczowa (1976).

The southern megabasin most probably had a character of one large lagoonal area which was fed with sea water through the above mentioned connections. Due to a high degree of evaporation and a low influx of freshwater, a high salinity was reached which probably severely restricted the living conditions for the invading faunas. Large-scale coastal sabhkas seem to have fringed the basin in which anhydritic claystone was deposited. In the centers of the basins halite was precipitated in playa-like conditions in periods of maximum desiccation (cp. Triassic facies map of Ziegler 1977). In marginal areas fluvial (?or aeolian) transported continental clastic deposits were laid down.

The low degree of freshwater supply to the basin is probably demonstrated in the composition of the microfloras. Orlowska-Zwolinska (1977) reports that pollen grains are the dominating element of the miospore spectra, whereas spores are rare. This means that the wind transported group prevails. In the Middle Bunter the spores were quantitatively predominant.

The evaporite beds are overlain by red-coloured claystones similar to those of the Bunter Shale Formation, which may mean that continental plain deposits of fluvio-lacustrine origin replaced the salt lake.

The climate was probably drier than during the deposition of the Bunter Sandstone and the above mentioned fossil and lithological records suggest an arid to semiarid, hot climate similar to that prevailing during the deposition of the Bunter Shale.

The facies types deposited in the Danish area (cp. pls. $1 \& 2$ and fig. 11) are in the lower part of the Ørslev Formation transitional between the playa or salt lake deposits of the basin center and the continental, clastic deposits of the northern margin, and are best classified as continental sabkha deposits. The upper part of the formation in which the anhydrite decreases may be classified as continental plain deposits of the low energy regime.

\section{Falster Formation new formation}

Type section. (fig. 13). Rødby 1 well, DGU File No. 240.75

$$
\begin{aligned}
& 54^{\circ} 41^{\prime} 37^{\prime \prime} \mathrm{N}-11^{\circ} 24^{\prime} 18^{\prime \prime} \mathrm{E} \\
& \text { Depth interval } \\
& 782 \mathrm{~m}-965 \mathrm{~m} \text { below M.S.L. } \\
& 2584^{\prime}-3185^{\prime} \text { below K.B. } \\
& \text { (SP+Res/SP+Res 1:500) }
\end{aligned}
$$

Thickness in type section: $183 \mathrm{~m}$

Reference section. (plate 1). Ørslev 1 well, DGU File No. 238.502

$$
54^{\circ} 46^{\prime} 55^{\prime \prime} \mathrm{N}-11^{\circ} 59^{\prime} 02^{\prime \prime} \mathrm{E}
$$

\section{Depth interval}

$818 \mathrm{~m}-958 \mathrm{~m}$ below M.S.L. $841.0 \mathrm{~m}-980.6 \mathrm{~m}$ below K.B. $(\mathrm{GR}+\mathrm{ITT} / \mathrm{GR}+\mathrm{ITT} 1: 200)$

Thickness in reference section: $140 \mathrm{~m}$

Derivation of name. The reference well is situated at the island of Falster. The name of the type locality Rødby - has by Larsen (1966) been used as formation designation for a Lower cretaceous, mainly Albian, reddish marlstone formation.

Remarks. The term Falster Formation is proposed for the lithological unit named the Muschelkalk in previous publications (e.g. Sorgenfrei \& Buch 1964). The reason for the abandonment of the widely used German term is the need for a true lithostratigraphical term. As with the term Röt, the Muschelkalk has been used in both a lithostratigraphical and a chronostratigraphical sense. 


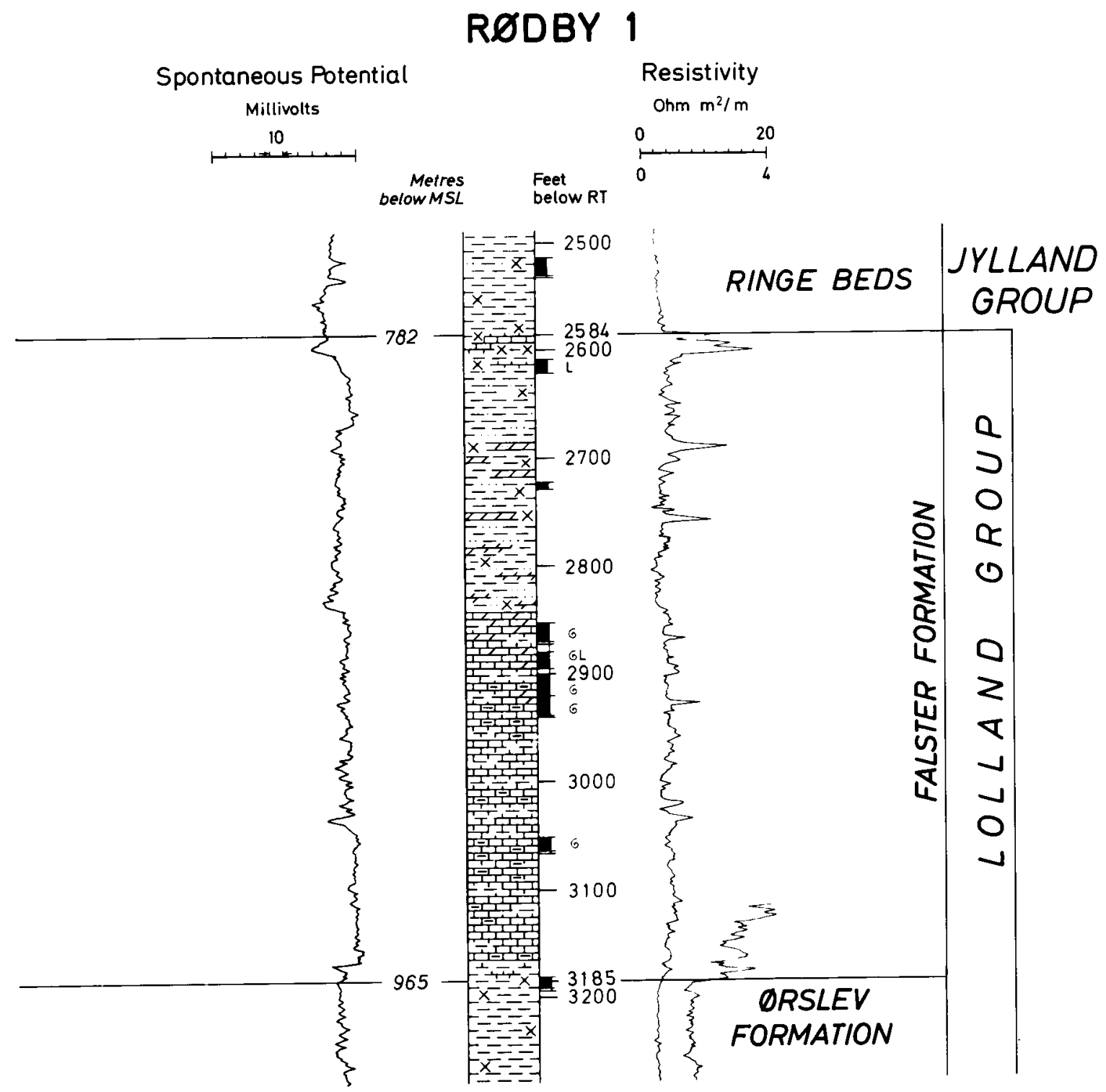

Fig. 13. Rødby 1. Type section of the Falster Formation. For Legend see fig. 9.

\section{Description}

\section{Lateral extension and thickness}

The lateral extension is shown on the map fig. 11. The distribution pattern corresponds with that of the Ørslev Formation, although it may be noted that the extension of the Falster Formation is wider. It is for instance present throughout the Horns Trough and in Skåne (Sweden). Transitional beds to the Skagerrak Formation are found in the wells Mors 1, Gassum 1, and Rønde 1 . The general thickness is $100-200 \mathrm{~m}$ in onshore wells, somewhat thicker in the southern part of the Horns Trough and the Central Graben (see table 4).

\section{Lithology}

The formation is tripartite. The lower part consists of interbedded and interlaminated claystone and lime- stone. The claystone is grey and greenish grey, locally also brown and red-brown, hard, mostly calcareous or dolomitic with nodules and seams of anhydrite. The limestone is clayey, greenish grey and greyish green, locally dolomitic, irregularly bedded with occasional highly fossiliferous bands, and with lumps and seams of anhydrite. The middle part consists of greenish grey and red-brown claystone as above, with minor bands of limestone, and with nodules and seams of anhydrite. In the southern part of the Horns Trough and the Central Graben the middle part is characterized by halite beds surrounded by light coloured greenish and reddish anhydritic marlstone. The upper part is developed as greenish grey to red-brown, claystone, with bands and beds of greenish grey, grey, dolomitic limestone, and anhydrite as inclusions, seams and freacture-fillings ("chicken-wire anhydrite"). Minor beds of greenish grey and calcareous 


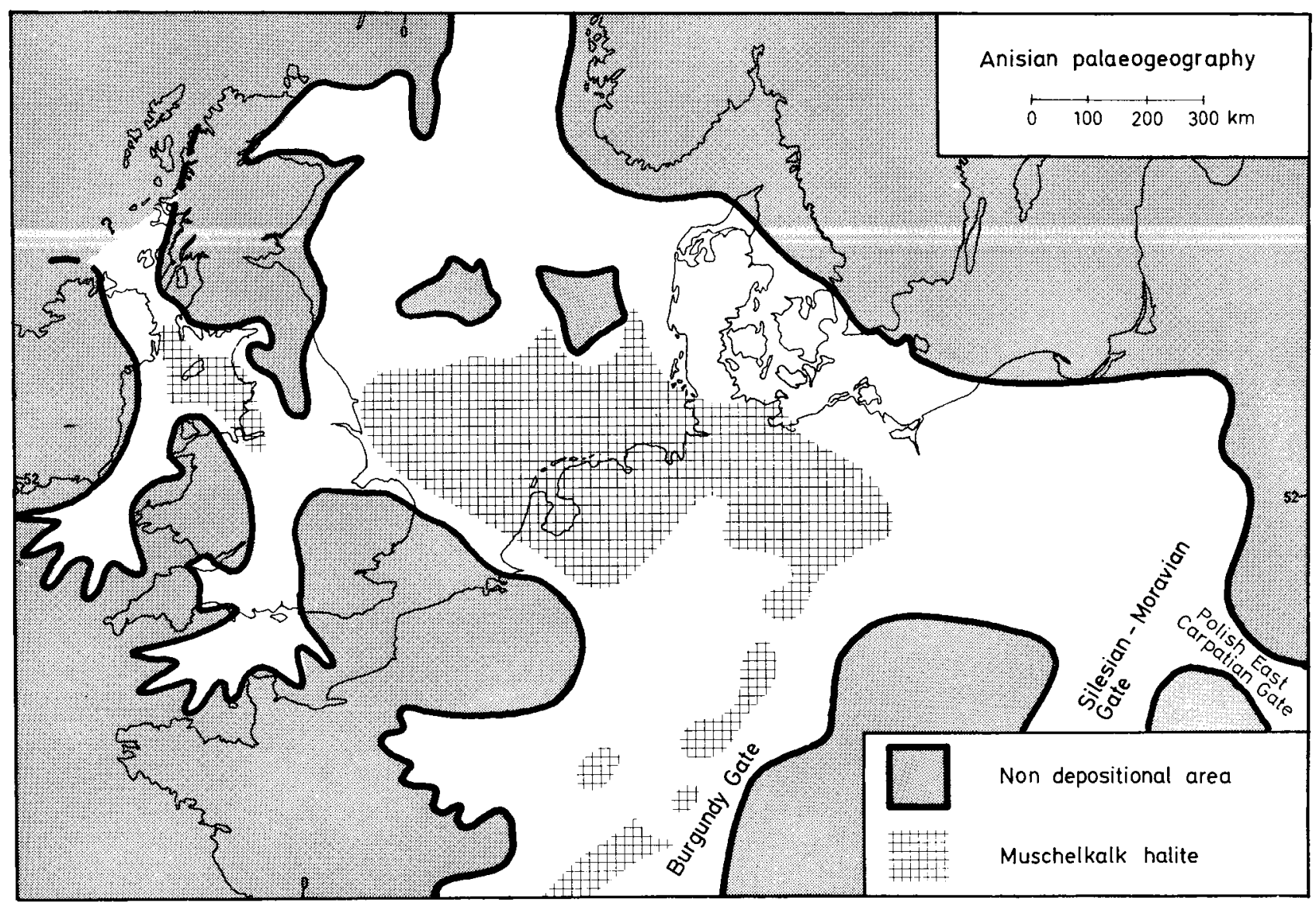

Fig. 14. Anisian palaeogeographic sketch map showing the Tethys connections with epicontinental basins. Mainly after Wurster (1964), Warrington (1970) and Senkowiczowa \& Szyperko-Sliwczynska (1975).

fine-grained, sandstone, may also be present. The sandstone may contain dispersed microlignite.

Log motifs and boundary definitions

The formation is normaly easily recognized on the wire line logs because of the numerous interbedded limestones and anhydrite layers showing peak motifs on the ITT, neutron, density and resistivity logs and because the formation is surrounded by claystone series with rather uniform motifs (pls. $1 \& 2$ ). Another distinct character of the formation is the predominant greenish grey clay colour in contrast to the red-brown colours below and above. The lower and the upper boundaries are set respectively below the lowermost and above the uppermost limestone/anhydrite peak.

\section{Subdivision}

The tripartition of the formation is thought to correspond to the German tripartite Muschelkalk: Lower, Middle and Upper Muschelkalk. A formal naming of the three parts (members) of the Falster Formation is still not worked out but is in progress. Some considerations about the subdivision possibilities may however be given: The lowermost member is most easy to single out because of its rather uniform character, with high content of limestone beds as indicated by the wire line logs (pls. $1 \& 2$ ). In general it makes up approximately the lower half of the formation. The separation of the middle and upper member is often less distinct especially in older wells with limited logging, but the log response of carbonate will probably permit the subdivision.

\section{Geological age}

Palynological studies on material from the onshore wells are only in the initial stages. Offshore studies (Bertelsen 1975 and D.G.U. internal reports) indicate an Anisian age for the Mushelkalk Halite member (middle member) in the Horns Trough and Central Graben (p. 44). Chara gyrogonites recovered from the upper part of the formation in the unlogged well Vinding 1 compare with assemblages described by Reinhardt \& Kozur (1969) from G.D.R.. The presence of Stellatochara germanicus Reinh. \& Kozur and $S$. höllvicensis Horn af Rantzien indicate a Ladinian age for these deposits. If the Falster Formation is considered more or less isochronous with the lithologically corresponding beds in the southern megabasin, an age range from late Scytian to Ladi- 
nian (pars) may be given (cp. Orlowska-Zwolinska 1977, Kozur 1975).

\section{Interpretation of the depositional history}

The deposits classified as Muschelkalk in the southern megabasin were formed under conditions which were highly controlled by the connection to the Tethys sea through three southern gates (fig. 14): the Polish East Carpathian Gate, the Silesian-Moravian Gate and the Burgundy Gate (Wurster 1964, Senkowiczowa \& Szyperko-Sliwczynska 1975, Kozur 1975).

Three main phases in the basinal development corresponding to the Lower, Middle and Upper Muschelkalk are recognized and may be summarized as follows - mainly based on Kozur (1975):

The Lower Muschelkalk represents a period of maximum marine influence, when the southern megabasin was covered by a shallow marine sea in which widespread bedded limestones were formed. The initial transgression took place through the Polish East Carpathian Gate and later also through the Silesian-Moravian Gate (cp. facies maps in Senkowiczowa \& Szyperko-Sliwczynska 1975). Towards the west the influence of the transgression gradually decreased and brackish conditions with deposition of dolomitic mudstones may have prevailed in the Southern North Sea - Central Graben area (cp. Geiger \& Hopping 1968, Brennand 1975).

The Middle Muschelkalk shows the characteristics of a regressive phase, such as disappearance or impoverishment of the fauna, formation of evaporites and red beds etc.. This event was probably due to uplift of the pre-Carpathian area followed by a closing of the Polish East Carpathian Gate and later by a deminished influx through the Silesian-Moravian Gate. Probably due to a high degree of evaporation combined with low fresh water influx and a steady supply of sea water, the southern megabasin developed into a hypersaline lagoonal area, in the deeper parts of which thick halite deposits were precipitated (fig. 14).

The final stage in the "Muschelkalk" development is marked by an opening to the Tethys sea through the Burgundy Gate (cp. Wurster 1964) and a closing of the Silesian-Moravian Gate. The Polish East Carpathian Gate also re-opened, but the faunistic influence through the Burgundy Gate in the form of an austroalpine fauna was of major importance. There are, according to Kozur l.c., however, indications of an eastern influence in the brackish water ostracod faunas found in the northeastern and eastern parts of the basin, which point towards an influence from the Polish East Carpathian Gate too.
The threefold depositional pattern recognized in the southern megabasin is in the Danish area traceable as far north as the facies change belt towards the Skagerrak Formation through the wells Mors 1, Gassum 1 and Rønde 1 (map fig. 11). The tripartion is however most distinct south of the RingkøbingFyn High in wells situated close to the northern extension limit of the Muschelkalk Halite. The presence of acritarchs in the palyno-assemblages in the Glamsbjerg 1 well on the "crest" of the Ringkøbing-Fyn High indicates that this high trend did not function as a barrier at that time and that it most probably was completely inundated. It may therefore be deduced that the southeastern, southern and central part of the Norwegian-Danish Basin was covered by a shallow marine sea during the deposition of the lower part of the Falster Formation. During the Middle Muschelkalk phase this area was probably occupied by a flat extensive sabkha as evidenced by the development of anhydrite/dolomitic variegated claystones in the middle part of the Falster Formation. The upper part of the formation corresponding to the Upper Muschelkalk shows that sabkha environments were interchanging with shallow brackish marine conditions, the latter being evidenced by the presence of Chara gyrogonites in the Höllviken 1, Slagelse 1 and Vinding 1 wells, in the central and southeastern part of the Norwegian - Danish Basin.

Judging from the sediment characters, the climatic conditions during the deposition of the Falster Formation seem to have been more or less the same as during the deposition of the Ørslev Formation that is, arid to semi-arid and rather hot. The precipitation of the evaporites in the middle part of the sedimentation period probably reflects a pronounced dry phase.

\section{Jylland Group new group}

The Jylland Group is proposed as formal name for the late Ladinian - Carnian - early Norian Tønder and Oddesund Formations described below.

The group consists mainly of reddish, brownish and greyish silty claystones with some anhydritic inclusions. Sandstones and siltstones are confined in general to the upper part of the lower formation, the Tønder Formation, whereas two, often prominent evaporitic series are present in the upper formation, the Oddesund Formation.

The Jylland Group overlies and is overlain by mainly greyish dolomitic claystones and thin, dolomitic limestones of the older Lolland Group and 


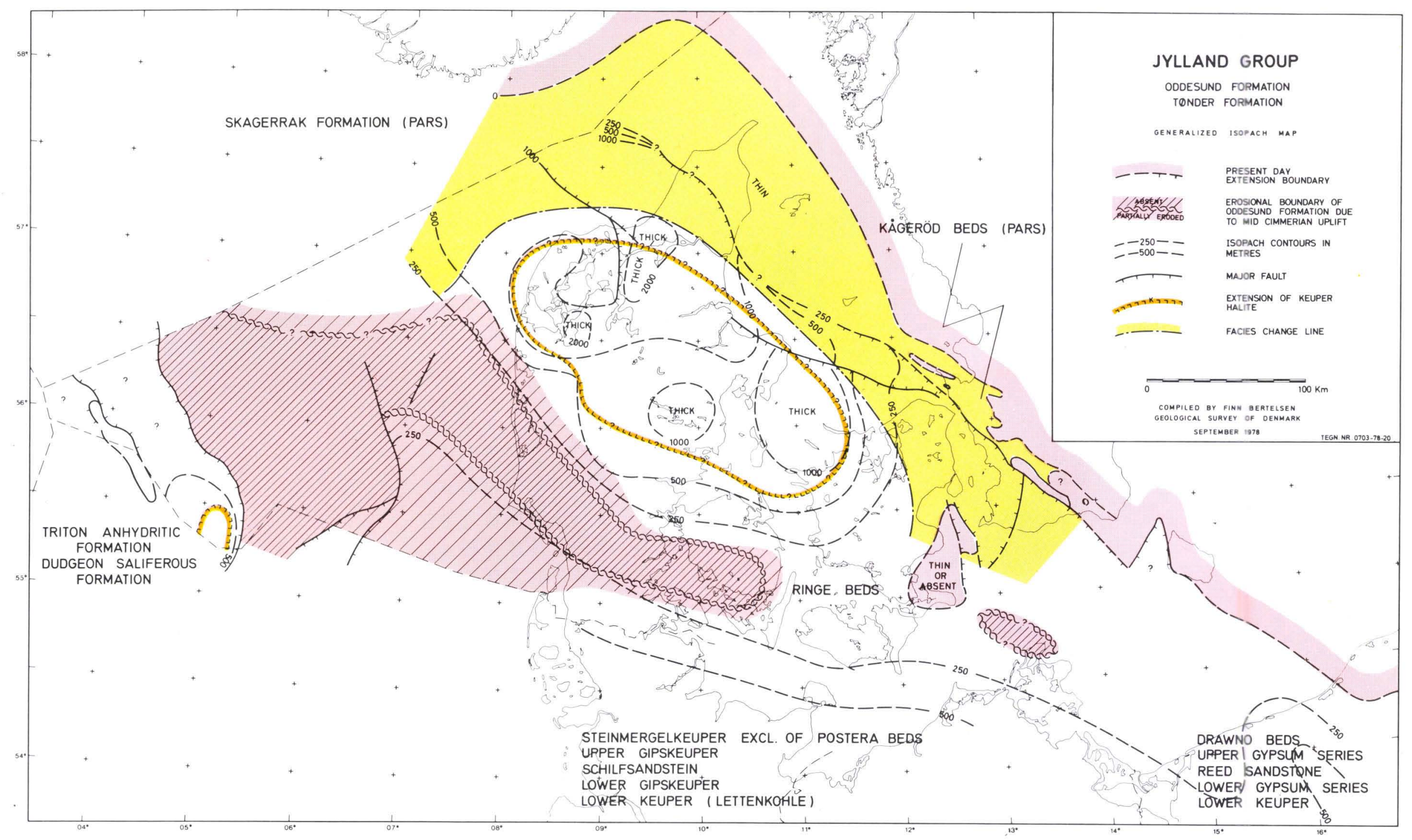

Fig. 15. Jylland Group isopach map. Compiled from well data and sources mentioned in the selected bibliography. 


\section{TONDER 1}

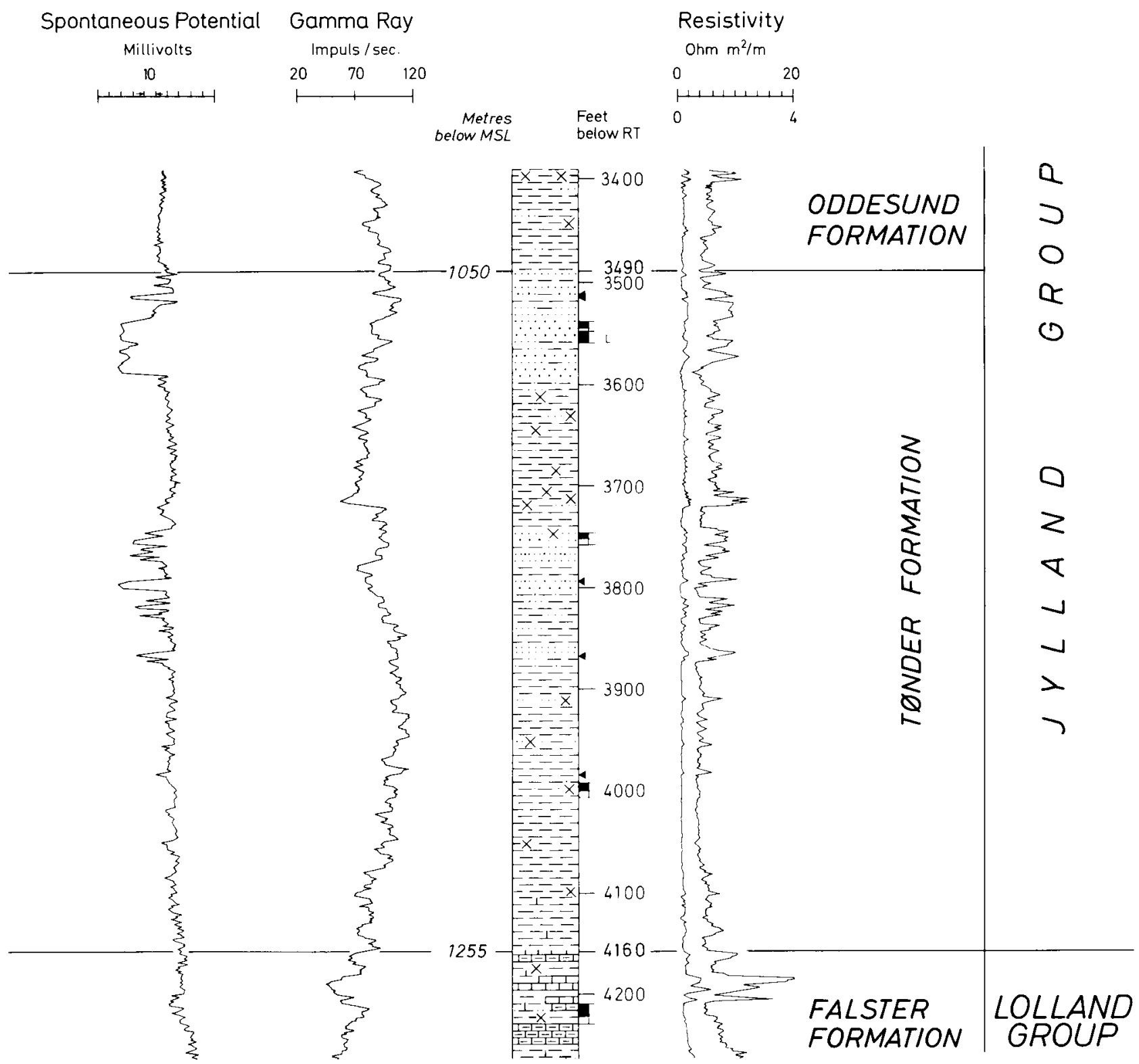

Fig. 16. Tønder 1. Type section of the Tønder Formation. For Legend see fig. 9.

the younger Mors Group, from which it differs more or less distinctively. To the north and northeast it grades into the arenaceous deposits of the Skagerrak Formation. The Jylland Group corresponds to the Lower and Middle Keuper in Germany, whereas the Southern North Sea equivalent is the upper part of the Haisborough Group (cp. fig. 7).

In the basin history the deposits of the Jylland Group represents the third, regressive megaphase of the Triassic.

The extension and thickness of the Jylland Group is shown on the map fig. 15 .
The group is named after the peninsula of Jylland (fig. 1) in which the type wells of the Tønder and Oddesund Formations are situated.

\section{Tønder Formation new formation}

Type section. (fig. 16). Tønder 1 well, DGU File No. 166.230

$$
54^{\circ} 57^{\prime} 37^{\prime \prime} \mathrm{N}-08^{\circ} 51^{\prime} 18^{\prime \prime} \mathrm{E}
$$




\section{Depth interval}

$1050 \mathrm{~m}-1255 \mathrm{~m}$ below M.S.L.

$3490^{\prime}-4160^{\prime}$ below K.B.E.

$(\mathrm{SP}+\mathrm{Res} / \mathrm{SP}+\operatorname{Res} 1: 500)$

Thickness in type section: $204 \mathrm{~m}$

Reference section. (plate 2). Hønning 1 well, DGU File No. 150.197

$55^{\circ} 10^{\prime} 51^{\prime \prime} \mathrm{N}-08^{\circ} 54^{\prime} 30^{\prime \prime} \mathrm{E}$

\section{Depth interval}

$1092 \mathrm{~m}-1261 \mathrm{~m}$ below M.S.L.

$1124 \mathrm{~m}-1293 \mathrm{~m}$ below K.B.E.

$(\mathrm{SP}+\operatorname{Res} / \mathrm{SP}+\operatorname{Res} 1: 1000)$

Thickness in reference section: $169 \mathrm{~m}$

Derivation of name. The formation is named after the type locality well.

Remarks. To avoid further confusion of litho- and chronostratigraphical terms the Tønder Formation is proposed as a formal lithostratigraphical name for the deposits, which in earlier publications e.g. Sorgenfrei \& Buch (1964), and reports were described as (Lower) Keuper. The term Keuper is of German origin.

\section{Description}

\section{Lateral extension and thickness}

The lateral extension is indicated on the map fig. 15 showing the distribution and thickness of the Jylland Group. The Tønder Formation may be partially eroded or absent over part of the Ringkøbing - Fyn High. To the north and northwest in the Danish Subbasin it grades laterally into the Skagerrak Formation. To the east, that is in the southeastern part of the Danish Subbasin the pelitic Ringe Beds (see later) seem to replace the Tønder Formation. In the offshore area the characteristic sand/siltstone bearing intervals of the formation are recognized in the C-1 and R-1 wells, but not in the southern, deep part of the Horns Trough or in the Central Graben.

The average thickness of the Tønder Formation is 100-300 m (see table 5).

\section{Lithology}

The formation consists of interbedded claystone, siltstone and sandstone. Sandstone beds occur mainly in the upper part of the formation, at least in the southernmost wells.
The claystone is commonly silty, occasionally finely sandy, variegated red-brown, chocolate-brown, grey-brown and greenish grey, the latter colour being observed mostly as spots. It is generally micaceous, variably calcareous (or dolomitic) to non-calcareous and with anhydritic inclusions. Greenish grey or reddish, calcareous siltstone, occurs subordinately in minor stringers and pockets within the claystone.

The sandstone is in general fine-grained, silty or slightly clayey, greenish grey or red-brown, micaceous, mainly non-calcareous and locally containing dispersed microlignite (as observed in cores from Tønder 1 and Vinding 1).

In the central part of the Danish Subbasin, the sandstone is fine- to medium-grained, slightly coarser, than in the wells of southern Jylland, where the sands are fine-grained grading into coarse silt. The first mentioned sandstone is mainly light brown in colour, is slightly arkosic, and may be calcareous or anhydrite cemented.

The sandstone beds of the southern wells are mainly restricted to the upper part of the formation, where two distinct members are commonly present. The upper one is about $10-30 \mathrm{~m}$ in thickness and rather massively bedded. The lower one is thicker, about $50 \mathrm{~m}$, and is divided by claystone intervals into individual beds commonly less than $10 \mathrm{~m}$ thick. To the north sandstone interbedded with claystone occurs throughout the formation. The sandstones are in general porous.

\section{Log motifs and boundary definitions}

The lower boundary is set by means of a SP - resistivity $\log$ at the top of the uppermost limestone/dolomite peak of the underlying Falster Formation (fig. 16; pl. 2). The boundary is also seen as a colour change from red brown above - to greenish grey below the boundary.

The upper boundary is set at the top of the uppermost sand member by the use of a SP - resistivity log or a gamma ray log in combination with a sonic log.

The SP log motifs of the claystone intervals (pls. 1 $\& 2)$ are rather even with minor serrate configurations probably showing minor silty beds. The resistivity $\log$ shows slightly higher readings in the basal claystone of the formation and in the claystone between the upper sandstones, which may be due to increased content of dolomite/anhydrite in these intervals.

The SP log motifs of the sandstone beds are generally "cylindrical" (even grain size) or "bell-shaped", (upward fining sequences). 


\section{Subdivision}

No formal subdivision is presented. The individual arenaceous intervals of the southern wells may gain member rank depending on future work.

\section{Geological age}

Neither palynological datings nor other biostratigraphical results are as yet available. In the North German Basin and the Polish Basin the corresponding beds, Lower Keuper or Lettenkohlenkeuper, are referred to late Ladinian (Langobardian) by means of mio- and megaspores, and Chara gyrogonites (Kozur 1972, Orlowska-Zwolinska 1977). See also Kozur (1975).

\section{Interpretation of the depositional history}

Uplifting of the region south of the pre-Carpathians caused the Central European sea to be disconnected from the geosynclinal sea to the south (Senkowiczowa \& Szyperko-Sliwczynska 1975). This event caused a freshening of the North German Basin and the Polish Basin, which for example is evidenced by the presence of Chara gyrogonites and brackish ostracod faunas (Kozur \& Reinhardt 1969). Already the 'Obere Ceratitenschichten' of the Upper Muschelkalk of northern Mecklenburg is by means of Chara gyrogonites shown to be brackish.

The lower pelitic part of the Tønder Formation was probably deposited in an environment similar to that of the Bunter Shale Formation, that is on a flat coastal plain not permanently covered by water, as witnessed by the predominantly red colours, the occurrence throughout of anhydrite, and so far as is known by the lack of fossils. Laterally these beds grade into fluvial deposits to the north. Increased river activity during the deposition of the upper part of the formation may have led to the deposition of the upper sand bearing part of the formation. The content of disseminated plant material noted in cores from the uppermost sand in the Tønder 1 well suggests that a hinterland flora had grown up. The equivalent sands in the Polish Basin are noted for their content of carbonized plant material by Senkowiczowa (1976) as is the German Lettenkohlensandstein (Geiger \& Hopping 1968).

The facies recovered in the North Sea wells of the Horns Trough and the Central Graben above the Muschelkalk are red coloured, anhydritic and palynologically barren. The sedimentary environments of these areas are comparable with those of southern Jylland.
The overall facies pattern of the Tønder Formation, and equivalent series, points towards hot, semi-arid climatic conditions during deposition. The influx of fluvial sands in the upper part of the Tønder Formation is interpreted as an increased humidity in the final stages of development.

\section{The Ringe Beds (new informal unit)}

In the southeastern part of the Danish Subbasin the Tønder Formation probably grades into the ?lower part of a lightcoloured marly claystone facies. This facies is here provisionally named the Ringe Beds after the "type well" Ringe 1 located on the island of Fyn (fig. 1). The claystone, which overlies the Falster Formation, is in part strongly calcareous and may grade into marlstone which is predominantly bluish grey to greenish grey, but with some reddish or brownish mottling. The Ringe Beds are recorded in the Ringe 1, the Slagelse 1, the Ørslev 1 and the Rødby wells.

The Ringe Beds contain a sparse fauna of Estheria sp. (Rødby 1, see Sorgenfrei \& Buch 1964). The deposit is interpreted as a product of low energy, shallow, brackish-marine environments.

The geographic position of the Ringe Beds is interesting because the same area contains the northernmost occurrences of the Rogenstein Member of the Bunter Shale in a structurally low area connecting the Danish Subbasin with the North German Basin. As seen from the Lower-Middle Keuper facies map of Rusitzka (1967) the continued connection with the Polish Basin took place south of Rügen. The analoguous palaeogeographic pattern was shown to exist during the later Norian - Rhaetian transgression (Bertelsen 1978) and the entrance to the Danish Subbasin was named the Storebælt Gate.

The age relationships of the Ringe Beds are not yet clarified, but may be resolved by future palynological investigations. The Ringe Beds are overlain by the late Norian - early Rhaetian Vinding Formation, and it is therefore at present not known whether they correspond fully or partially to the Tønder Formation, the younger Oddesund Formation or to both formations.

The absence of sands in the Ringe Beds may be due to deposition in low energy environments, but may also be explained as a secondary phenomena caused by pre-Rhaetian erosion, which could mean that the Ringe Beds may correspond to the lower pelitic part of the Tønder Formation. Another explanation may be derived from the result of a heavy 
mineral analysis of the uppermost part of the "Tønder" sands by Larsen \& Friis (1975). The sample is unusually rich in titanite, and the authors state, that exposed parts of the Ringkøbing-Fyn High may have been the source area. There is therefore a possibility that certain conditions over the Ringkøbing-Fyn High may have favoured the arenaceous accumulations found in the southern Jylland.

\section{Oddesund Formation new formation}

Type section. (fig. 17). Mors 1 well, DGU File No. 31.50

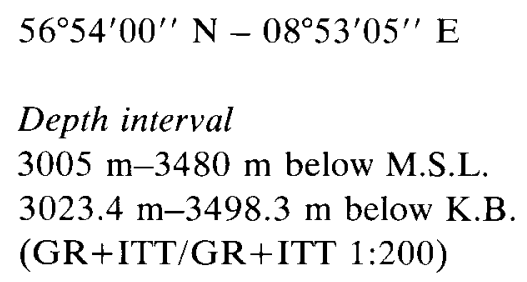

Thickness in type section: $475 \mathrm{~m}$

Reference section. (plate 1). Rønde 1 well, DGU File No. 80.164

$$
\begin{aligned}
& 56^{\circ} 18^{\prime} 15^{\prime \prime} \mathrm{N}-10^{\circ} 26^{\prime} 07^{\prime \prime} \mathrm{E} \\
& \text { Depth interval } \\
& 2782 \cdot \mathrm{m}-3415 \mathrm{~m} \text { below M.S.L. } \\
& 2824.6 \mathrm{~m}-3457.0 \mathrm{~m} \text { below K.B. } \\
& (\mathrm{GR}+\mathrm{N} / \mathrm{GR}+\mathrm{N} 1: 200)
\end{aligned}
$$

Thickness in reference section: $632 \mathrm{~m}$

Derivation of name. The formation is named after the Oddesund 1 well in which an unusually great thickness was drilled, without, however, complete penetration of the formation.

Remarks. The name of the formation was informally introduced by the present author in DGU internal reports and later in publication (1978) for the evaporite bearing claystone series formerly referred to as Middle Keuper, and stratigraphically situated between the Tønder Formation below and the Vinding Formation above in the Danish Subbasin. Earlier descriptions of well sections are given in Sorgenfrei \& Buch (1964) and Dinesen (1971, 1973). In the Horns Trough and the Central Graben the corresponding beds have been referred to in DGU internal reports as the Dudgeon Saliferous Formation + the Triton Anhydritic Formation (Rhys 1974) following the Southern North Sea Basin nomenclature.

\section{Description}

\section{Lateral extension and thickness}

The distribution of the Oddesund Formation is shown on the map fig. 15. In the type region, the central part of the Danish Subbasin, only a limited number of well data are available because only a few wells have been drilled for pre-Triassic objectives. The seismic reconnaissence of the formation in this region is however facilitated by the presence of thick salt bearing members (see below). To the north and northwest the formation grades laterally into the arenaceous Skagerrak Formation as evidenced by palynology in for example the Dansk Nordsø F-1 well (Bertelsen 1975). To the south the formation continues into the North German Basin, but due to Mid-Cimmerian uplift and subsequent erosion the beds have been removed over the crest of the Ringkøbing - Fyn High. In the eastern and southeastern part of the Danish Subbasin the formation most probably grades into marginal arenaceous deposits (Kågerod Beds in Skåne), ?the Ringe Beds (see p. 32) or is absent due to pre-Rhaetian uplift and erosion. On the island of Bornholm in the Baltic Sea the red bed sequences known from shallow wells at Sorthat (H. Gry, pers. communication) and from coastal outcrops at Risebæk (Christensen 1972) may be contemporaneous with the Oddesund Formation.

The thickness of the formation (table 6) is rather variable due to the beginning of halokinesis of the Zechstein salt during deposition. The halokinesis was triggered by increased tectonic activity and rate of subsidence. Later halokinesis of the salt beds of the formation itself leading to irregularities in thickness have been noticed locally (east of the island of Mors). The maximum thickness drilled is approximately $1500 \mathrm{~m}$.

\section{Lithology}

The formation consists of red-brown, brown and grey, variegated, variably micaceous, calcareous, anhydritic, pyrite and microlignite bearing claystone and siltstone. Thin beds of dolomitic limestone and marlstone occur sporadically. Two prominent members of in part clayey, colourless, grey or pink halite are present in the central part of the basin. Towards the margins of the basin these beds grade into strongly anhydritic claystones. In the northern wells an increased content of silt or fine-grained sand is seen in the beds separating the two evaporite members. 


\section{MORS 1}

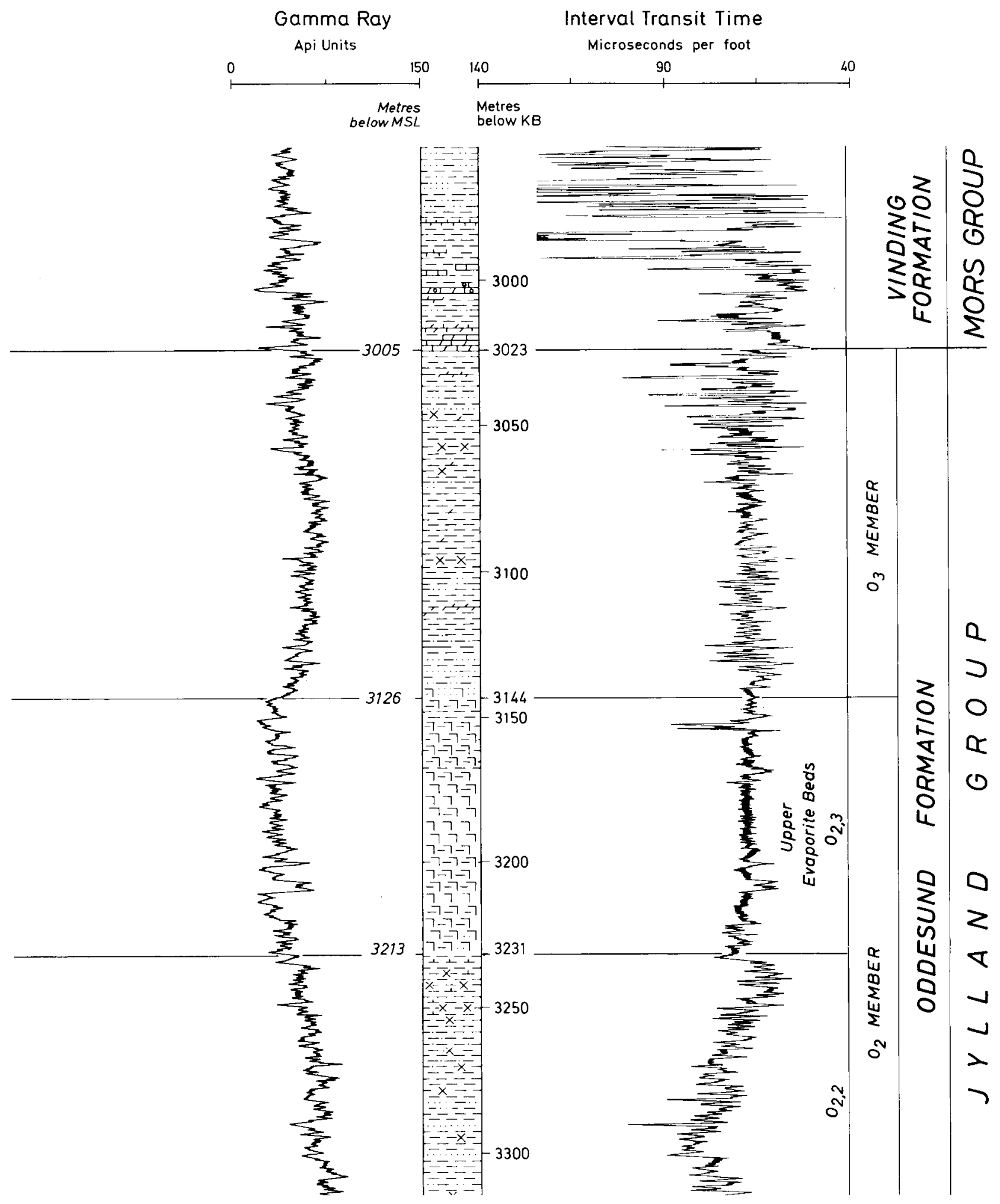




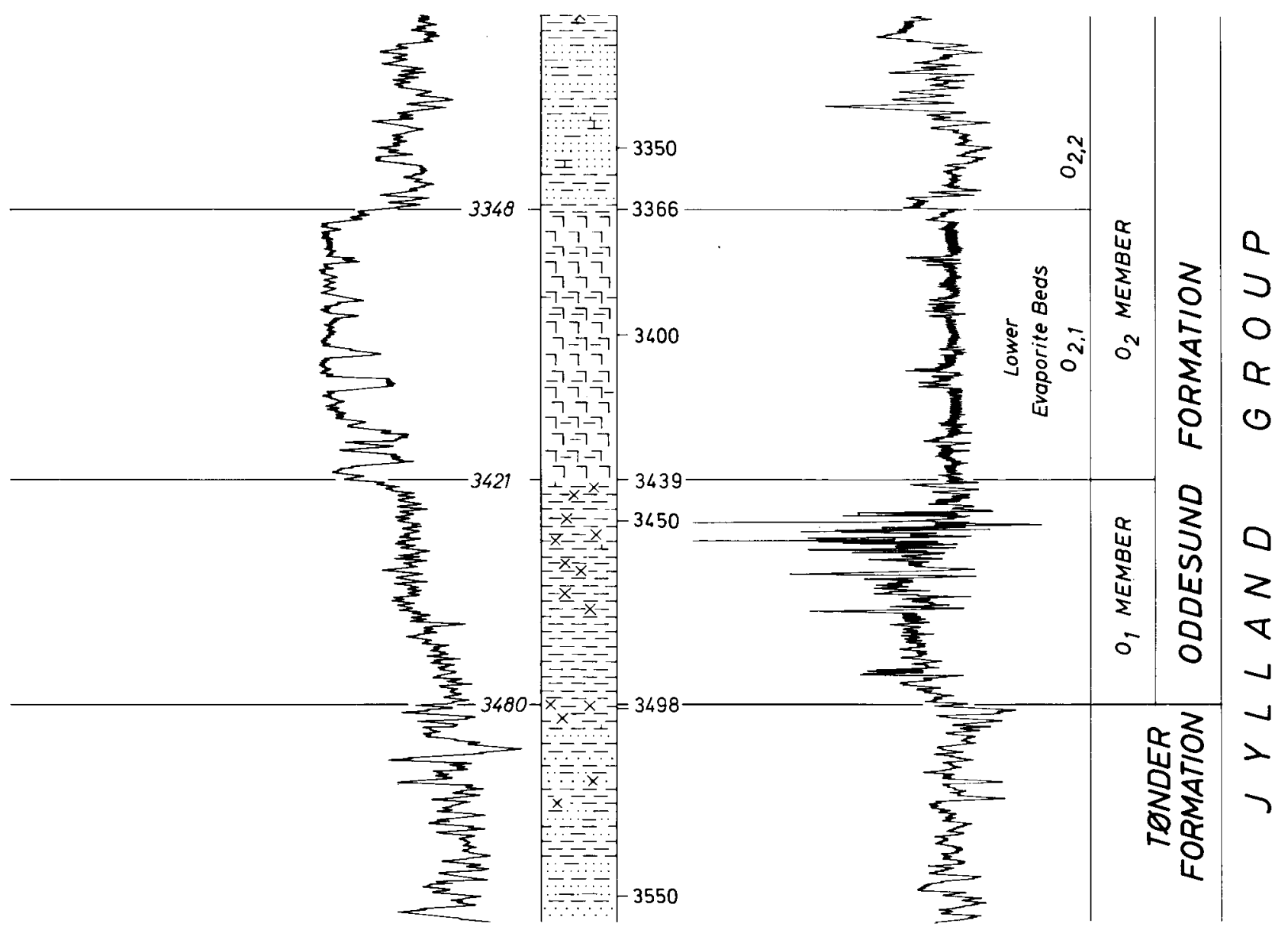

Fig. 17. Mors 1. Type section of the Oddesund Formation. For Legend see fig. 9.

Log motifs and boundary definitions

The lower boundary is set by means of a gamma ray ITT $\log$, a SP - resistivity log and other adequate logs at the top of the silt/sandstone of the underlying Tønder Formation (fig. 17; pl.1). The upper boundary is in non-eroded sections set at the base of the Vinding Formation (cf. Bertelsen 1978) which is commonly marked by a distinct peak motif on the gamma ray $\log$ corresponding to a basal dolomite bed. The evaporite beds are easily recognized on the resistivity logs, showing high readings. When halite is present, rather uniform straightlined ITT log motifs indicate rather clean salt deposits. The variable lithology of claystone, siltstone, anhydrite and minor limestone in the other members is seen as rather irregular serrate log motifs. A gamma ray log in combination with bulk density/neutron overlay may facilitate the interpretation.

\section{Subdivision}

The Oddesund Formation has been informally divided into three members in DGU internal reports: (from below) $\mathrm{O}_{1}, \mathrm{O}_{2}$ and $\mathrm{O}_{3}$. The $\mathrm{O}_{2}$ member con- tains the evaporitic beds. It is however evident that the $\mathrm{O}_{2}$ member can be subdived in three units, a lower and an upper evaporitic unit separated by a claystone/siltstone unit, which are designated $\mathrm{O}_{2,1}$, $\mathrm{O}_{2,2}$ and $\mathrm{O}_{2,3}$. The $\mathrm{O}_{2,1}$ is informaly named the Lower Evaporitic Beds $(3348 \mathrm{~m}-3421 \mathrm{~m}$ below M.S.L. in Mors 1 well) and the $\mathrm{O}_{2,3}$ the Upper Evaporitic Beds $(3126 \mathrm{~m}-3213 \mathrm{~m}$ below M.S.L. in Mors 1 well). The main characters of the individuel units may be seen from the following description of the type profile and from fig. 17.

Depth below

K.B. Lithology

3023 - 3144 m Claystone, dark grey, soft, calcare$\mathrm{O}_{3} \quad$ ous and dominating in the lower part siltstone, greyish and reddish, clayey, calcareous. Limestone, dolomitic, grey brownish, reddish, often clayey or sandy, occurs sporadically but more frequently in the lower part. 
$3144-3231 \mathrm{~m}$ Halite, clear or slightly yellowish $\mathrm{O}_{2,3}$ with interbedded claystone (or embedded in claystone) grey to red-brown, calcareous and minor siltstone.

3231 - 3322 m Claystone, grey, shaly with depth $\mathrm{O}_{2,2} \quad$ becoming increasingly brown and soft, anhydritic and calcareous, with various amounts of silt content. Also siltstone, greyish brown to moderate brown, clayey, anhydritic and with calcite fracture fillings.

$3322-3366 \mathrm{~m}$ Siltstone, clayey, sporadically $\mathrm{O}_{2,2} \quad$ sandy, with minor interbeds of claystone.

3366 - $3439 \mathrm{~m}$ Halite, clear with some reddish $\mathrm{O}_{2,1} \quad$ portions and with greyish and reddish claystone.

$3439-3498 \mathrm{~m}$ Claystone, red-brown. to light $\mathrm{O}_{1}$ olive-grey, mainly soft and calcareous with inclusions of white anhydrite. Claystone, grey occurs frequently (probably cavings).

\section{Geological age}

Palynological datings of core samples from the salt-clay (Gassum 1, Oddesund 1) indicate a mainly Carnian age of the Oddesund Formation. The uppermost part of the formation may probably correspond to the early Norian as suggested by the composition of the ostracod assemblages in the conformably overlying Vinding Formation, as well as by palynology (Bertelsen 1978).

\section{Interpretation of the depositional history}

The depositional pattern seen in the Oddesund Formation is recognized elsewhere in the Northwest European Basin. In the Polish Basin the evaporite members are known as the Lower and Upper Gypsum Series (Senkowiczowa \& Szyperko-Sliwczynska 1975), whereas the corresponding beds in Germany are named Unterer Gipskeuper and Oberer Gipskeuper (Rote Wand) (Rusitzka 1967, Kozur 1975). In the Southern North Sea Basin the lower evaporite is known as the Keuper Halite Member of the Dudgeon Saliferous Formation, whereas the upper evaporite is termed the Keuper Anhydritic Member of the Triton Anhydritic Formation (Rhys 1974, Brennand 1975). In England the evaporites are de- scribed under various names in the different basins. A tentative correlation was presented by Warrington (1970). As in the Southern North Sea Basin halites seem mainly confined to the lower beds. The two evaporite members are in some marginal areas separated by fluvial or fluvio-deltaic arenaceous sequences known in Poland as the Reed Sandstone, in Germany as Schilfsandstein, in England as Arden Sandstone Member (Cheshire) or other local names (sources as cited above).

This cyclical development in the course of sedimentation is interpreted by most authors as due to climatic fluctuations. The evaporitic beds were formed during periods of increased aridity, whereas the intervening deltaic deposits represent increased humidity with extensive fluvial activity.

The occurrence of halite is limited to the depocentres of the various sedimentary basins. In the southern megabasin the extension of the Keuper Halite is more restricted than that of the former Röt and Muschelkalk salts in the Southern North Sea Basin and the Northwest German Basin. In the Polish Basin and the Danish Subbasin halites occur for the first time in Triassic history (although it may be noted that Röt Halite is found in the westernmost Poland). The anhydritic beds are found as a fringing facies belt which surrounds the halite deposits. The anhydritic beds grade towards the margins into continental clastic red beds.

It is thought, that the Keuper halites were precipitated from hypersaline brines in areas of permanent water cover during conditions comparable to those existing during the precipitation of the Röt and Muschelkalk halites as discussed earlier (p.25,28).Preservation of pollen and occurrence of grey clay colours in the salt clay are in this connection taken as an indication of non-oxidizing chemical environments. The origin of the halite is more problematical. The precipitation of the Keuper halites did not follow a transgressive phase as was the case with the formation of the Röt and Muschelkalk halites and a feeding of the basins with sea water is therefore difficult to accept as source theory. There is, however, evidence for a connection to the Tethys through the south-southwestern part of the German Basin during the upper Triassic (Kozur 1975) and it is not unlikely that the lagoonal basins were supplied with sea water through this gate. The faunistic impoverishment is explained by Kozur as being due to unfavourable chemical conditions in the epicontinental area.

The very thick development of the halites in the Danish Subbasin may however be due in part to re-working of the Zechstein halite. Glennie (1970,p. 57) mentions, that in some regions of Iran the salinity 
of the river waters is increased by addition of salt from exposed salt diapirs, and it is not unlikely that similar conditions may have existed in the Danish Subbasin. Seismic profiles from the center of the basin show that halokinesis began during the deposition of the Oddesund Formation and there is therefore a possibility, that Permian salt plugs contributed to the formation of the Keuper halite by erosion and ground water leaching.

Between the formation of the two evaporitic sequences a period of increased humidity may have existed. Well documented examples of deltaic deposition in the basin margins are presented by Gajewska (1973) (Polish Reed Sandstone) and by Wurster(1964), Stets \& Wurster (1977) (Schilfsandstein of Bayern, S-Germany). During this period the net surplus of water from the epicontinental area drained to the Tethys through the Burgundy Gate (cp. palaeogeographic maps in Wurster 1964 and Senkowiczowa \& Szyperko-Sliwczynska 1975).

The microfossils recovered from the Schilfsandstein and Reed Sandstone are indicative of limnic to brackish water environments, the assemblages consisting of ostracods, megaspores and Chara gyrogonites (Kannegieser \& Kozur 1972, Gajewska 1973, Kozur 1975, Fuglewicz 1977b). The microflora of the Reed Sandstone described by Orlowska-Zwolinska (1976) is highly irregular in composition from locality to locality, which it is suggested is due to fluvial controlled sedimentation.

Due to the lack of drilling information it is still unknown if deltaic deposits corresponding to the Schilfsandstein are present along the northern margin of the Danish Subbasin. The discovery of a pollen bearing, organic rich interval in the otherwise oxidized well section of the Skagerrak Formation in the Dansk Nordsø F-1 well (Bertelsen 1975) situated in the northwestern margin of the subbasin may point towards the existence of such deposits.

In summary, the Oddesund Formation may be characterized as a deposit formed during prevailing brackish to hypersaline environmental conditions. Periodically flooded sabkhas and ephemeral lakes may have occupied vast areas, whereas more permanent salt lakes existed in the rapidly subsiding center of the Danish Subbasin. The increased subsidence rate is accompanied by accentuated faulting along the Fjerritslev Fault trend and also the Fennoscandian Border Zone seems to have been tectonically active. In the Horns Trough faulting is noticed along the East North Sea Block (cp. fig. 5). The results of the tectonic events are 1) extension of the sedimentation area across the Fennoscandian Border Zone, 2) formation of rapidly subsiding "half-grabens" along the major branches of the Fjerritslev Fault and 3) triggering of the halokinetic movements of the Zechstein salt, which reinforced the unstable sedimentary conditions in the subbasin center.

The climate, which became at least semi-humid during the deposition of the Tønder Formation, was arid to semi-arid during the early and late phase of deposition of the Oddesund Formation. In an intermediate phase the humidity was comparable with the "Tønder" phase. The distribution of anhydrite in the sediments points towards a rather hot climate throughout the period.

\section{Mors Group new group}

The Mors Group is proposed to comprise the late Norian to early Jurassic Vinding and Gassum Formations, which were redefined and mapped individually by Bertelsen (1978). Originally the two formations were erected by Larsen (1966).

The unifying rock characteristics of the two formations which form the basis for the recognition of a group are the predominance of dark, grey clay colours throughout the main part of the unit. The sediments are mainly of detrital origin, but limestones occur especially in the lower part of the group. The group represents transitional facies between the continental red beds of the Jylland Group described above, and the shallow-marine, dark grey claystones of the Fjerritslev Formation (Michelsen 1978a) overlying the group.

The Vinding Formation was deposited in shallow, brackish-marine environments, whereas the Gassum Formation is of mainly fluvio-deltaic origin. In the overall Triassic history the Mors Group represent the deposits of the fourth, transgressive megaphase.

In the center of the basin the top of the Gassum Formation corresponds approximately to the Triassic/Jurassic boundary. In the Northern Marginal Facies Province the Gassum Formation ranges into the Sinemurian (see Christensen 1973 (p. 123), Michelsen 1975 (p. 48), and Bertelsen 1978 (p. 18)).

The map (fig. 18) shows the extension and thickness of the Triassic part of the Mors Group.

The name of the group is derived from the island of Mors in northern Jylland (map, fig. 1) situated in the late Triassic - early Jurassic depocenter of the Danish Subbasin.

Well data of the Vinding and Gassum Formations are given in tables $7 \& 8$. 


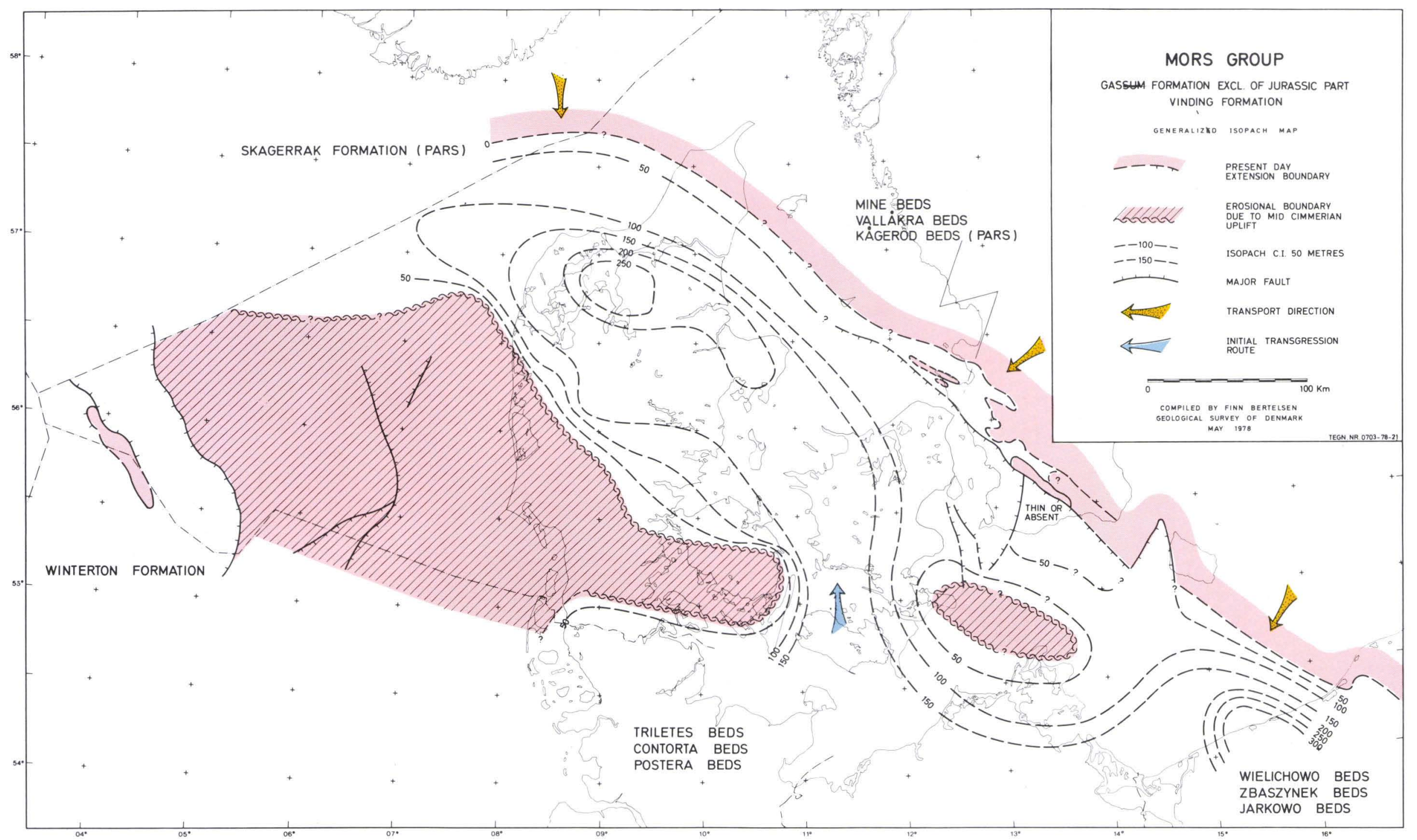

Fig. 18. Mors Group isopach map exclusive of the Jurassic part of the Gassum Formation. Compiled from well data and sources mentioned in the selected bibliography. 


\section{The Northern Marginal Facies Province}

This province comprises the northwestern, northern and eastern margin of the Danish Subbasin. Towards the northwest the Norwegian part of the Norwegian-Danish Basin (the Egernsund Subbasin) is fully included in this province. The transition zone towards the Germano-type Facies Province is situated in the central part of the Danish Subbasin as indicated by the sand/shale ratios or the facies change lines on the maps (figs. 8,11,15). Chronostratigraphically the province comprises the preRhaetian Triassic deposits.

The deposits which generally may be characterized by a clastic, red bed sequence of northern and northeastern origin are divided by Deegan \& Scull (1977) into a basal - distal, mainly pelitic unit, the Smith Bank Formation, and an upper - proximal arenaceous unit, the Skagerrak Formation. In Skåne (Sweden) the beds thought to be equivalent to the upper part of the Skagerrak Formation are known as the Kågeröd Beds. Deegan \& Scull (1977) did not include the two formations in a formal group, as they awaited further information for correlation with the region south of the Mid North Sea High - Ringkøbing-Fyn High. Instead the formations are included in the informal Triassic Group.

\section{Smith Bank Formation Deegan \& Scull} 1977

Type section. (Deegan \& Scull 1577, fig. 12). BP 15/26-1 well, U. K. North Sea sector $58^{\circ} 05^{\prime} 48.5^{\prime \prime} \mathrm{N}-00^{\circ} 07^{\prime} 55.6^{\prime \prime} \mathrm{E}$

Depth interval

$2454 \mathrm{~m}-3053 \mathrm{~m}$ below M.S.L.

$8163^{\prime}-10128^{\prime}$ below K.B.E.

$(\mathrm{GR}+\mathrm{ITT} / \mathrm{GR}+\mathrm{ITT})$

Thickness in type section: $599 \mathrm{~m}$

Reference section. (fig. 19). Dansk Nordsø D-1 well $56^{\circ} 25^{\prime} 29.7^{\prime \prime} \mathrm{N}-05^{\circ} 31^{\prime} 52.2^{\prime \prime} \mathrm{E}$

Depth interval

$1634 \mathrm{~m}-1687 \mathrm{~m}$ below M.S.L.

$5482^{\prime}-5656^{\prime}$ below K.B.E.

$(\mathrm{GR}+\mathrm{ITT} / \mathrm{GR}+\mathrm{ITT} 1: 200)$

Thickness in reference section: $53 \mathrm{~m}$.
Remarks. The formation is imperfectly known in the Danish area and is in fact only recognized in the reference well. The lowermost shaly sections of the Triassic columns in the Rønde 1 and Gassum 1 wells lying in the transition zone towards the Germano-type Facies Province are, however, comparable with the Smith Bank Formation.

\section{Description}

\section{Lateral extension and thickness}

The thickness of the formation within Danish waters is unknown. The limited thickness in the distally situated D-1 well probably indicates a rather thin development in the eastern part of the Norwegian Danish Basin. The lateral extension which may be similar to that of the Zechstein is shown on the Bacton Group map fig. 8 .

\section{Lithology}

In the reference section the formation consists of silty, red-brown, claystone, with lighter coloured and more silty patches (Rasmussen 1974).

\section{Log motifs and boundary definitions}

The lower boundary of the formation in the reference well is, in accordance with Deegan \& Scull (1977), placed by means of a gamma ray - ITT log, at the top of the underlying Zechstein anhydrites, which the formation overlies conformably. The upper boundary towards the overlying more arenaceous Skagerrak Formation is less well defined, and is somewhat gradational. It is drawn at a point where the gamma ray - ITT log indicates an upwards increasing, generally higher content of silt-sand in the sequence. The interchanging lithology of the formation results in a serrate set of $\log$ motifs.

\section{Geological age}

In the eastern and the southern part of the Norwegian - Danish Basin the formation is most probably of late Upper Permian to early Triassic (Scythian) age, thus corresponding to the lower part of the Bunter Shale Formation.

\section{Interpretation of the depositional history}

The formation represents distal, continental plain deposits of an arid to semi-arid, hot climate. To the south the Smith Bank Formation seems to continue in the Bunter Shale Formation, from which it is not readily distinguished. 


\section{DANSK NORDS $\emptyset$ D-1}

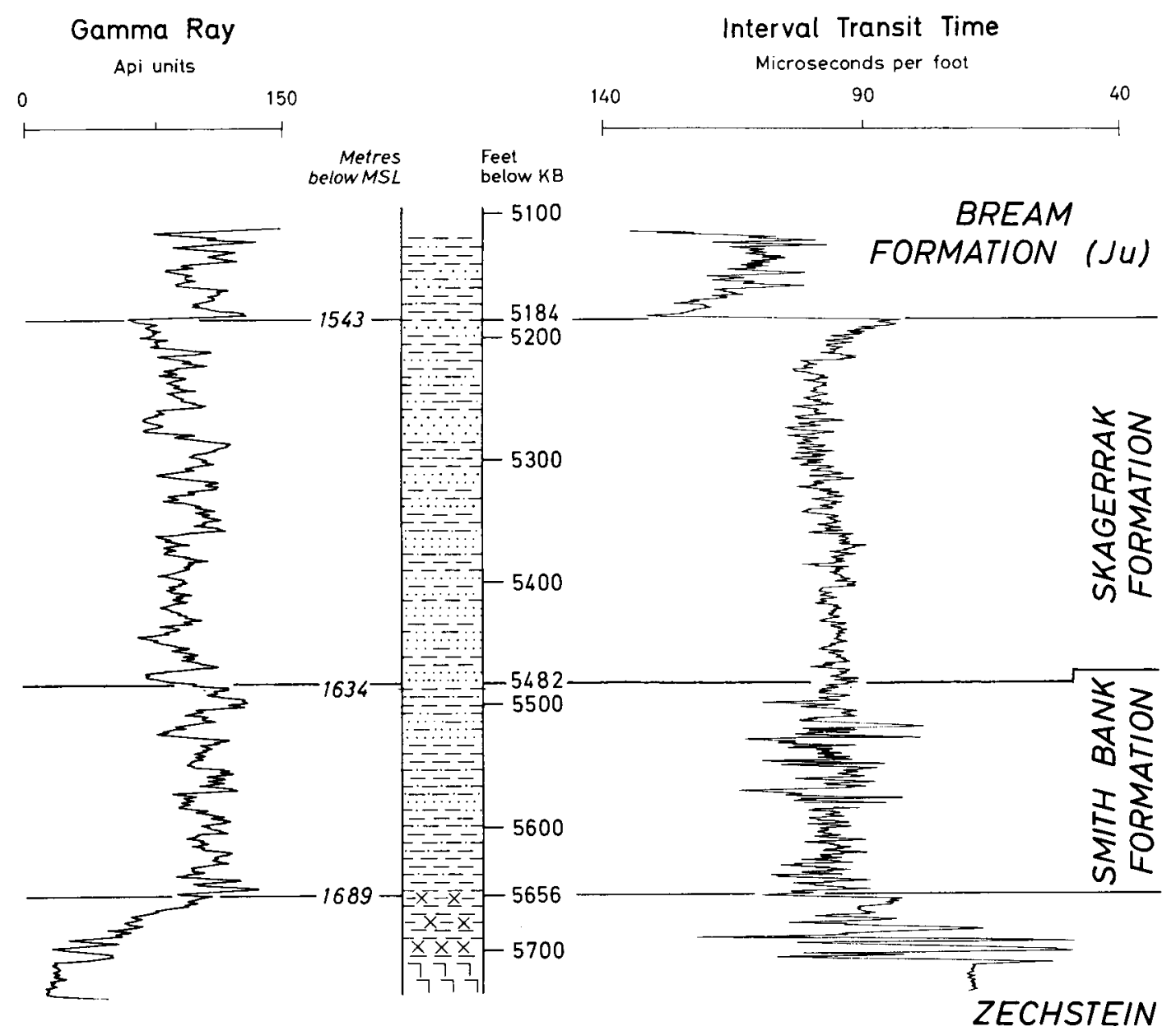

Fig. 19. Dansk Nordsø D-1. Reference sections of the Smith Bank Formation and the lowermost part of the Skagerrak Formation. For Legend see fig. 9.

\section{Skagerrak Formation Deegan \& Scull} 1977

Type section. (Deegan \& Scull 1977, fig. 14). Elf Norge 10/8-1 well, Norwegian North Sea sector $57^{\circ} 25^{\prime} 00.009^{\prime \prime} \mathrm{N}-05^{\circ} 34^{\prime} 21.706^{\prime \prime} \mathrm{E}$

Depth interval

$1543 \mathrm{~m}-2725 \mathrm{~m}$ below M.S.L.

$5140^{\prime}-9017^{\prime}$ below K.B.E.

$(\mathrm{GR}+\mathrm{ITT} / \mathrm{GR}+\mathrm{ITT})$

Thickness in type section: $1182 \mathrm{~m}$

Reference section (lower part). (fig. 19). Dansk Nordsø D-1 well.

$56^{\circ} 25^{\prime} 29.7^{\prime \prime} \mathrm{N}-05^{\circ} 31^{\prime} 52.2^{\prime \prime} \mathrm{E}$

Depth interval

1543 m-1634 m below M.S.L. $5184^{\prime}-5482^{\prime}$ below K.B.E.

$(\mathrm{GR}+\mathrm{ITT} / \mathrm{GR}+\mathrm{ITT} 1: 200)$

Thickness: $91 \mathrm{~m}$

Reference section (upper part). (fig. 20). Dansk Nordsø F-1 well.

$$
\begin{aligned}
& 57^{\circ} 01^{\prime} 53^{\prime \prime} \mathrm{N}-06^{\circ} 54^{\prime} 29^{\prime \prime} \mathrm{E} \\
& \text { Depth interval } \\
& 2117 \mathrm{~m}-2385 \text { m below M.S.L. } \\
& 7068^{\prime}-7945^{\prime} \text { below K.B.E. } \\
& \text { (GR+ITT/TD (Log.) 1:200) }
\end{aligned}
$$

Thickness: $267 \mathrm{~m}$

Remarks. The formation was proposed by Deegan \& Scull (1977) for the marginal, mainly reddish deposits of interbedded conglomerates, sandstones, siltstones and claystones of middle (?early) to late 


\section{DANSK NORDS $\emptyset$ F-1}

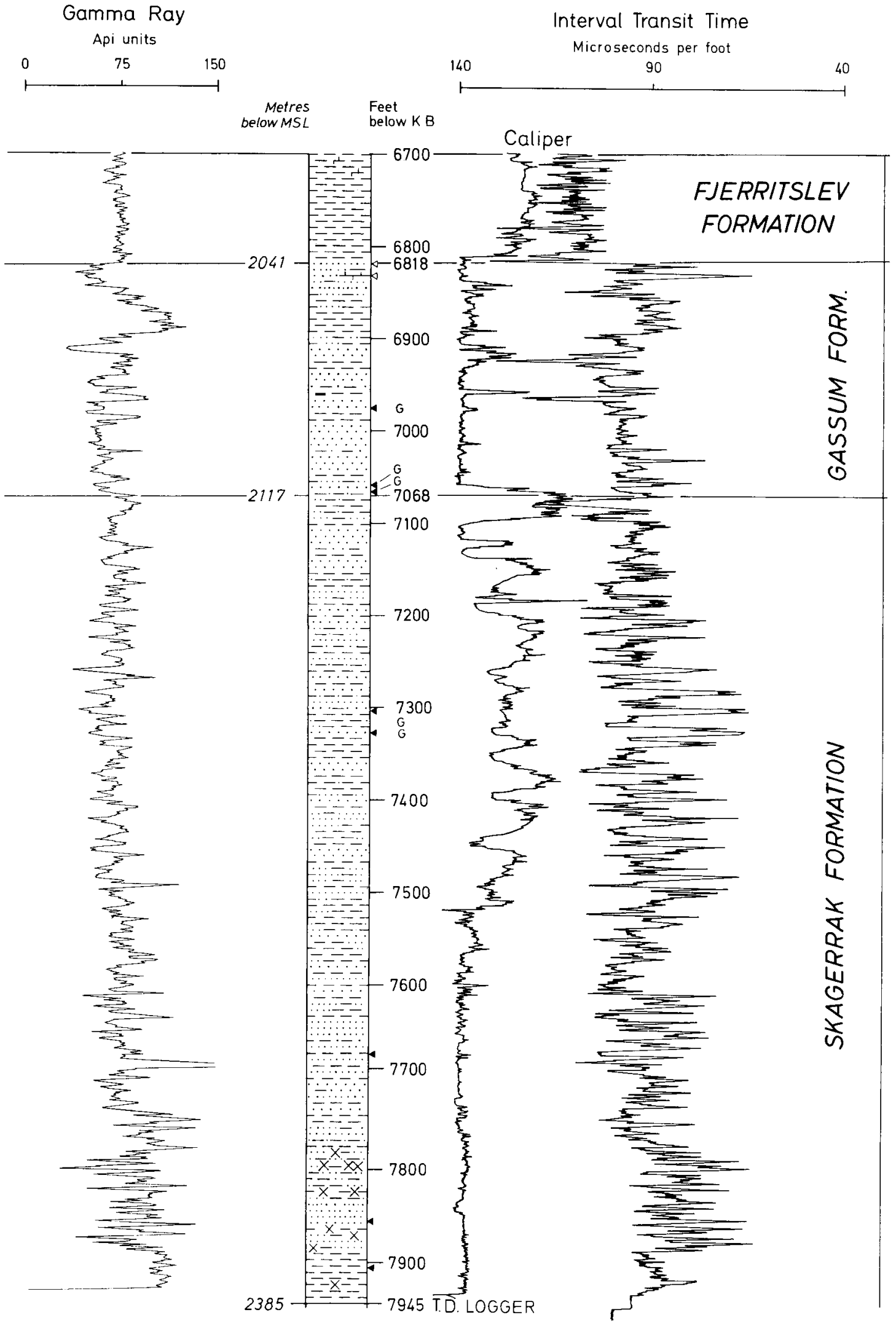

Fig. 20. Dansk Nordsø F-1. Reference section of the upper part of the Skagerrak Formation. For Legend see fig. 9. Note that the caliper log is recorded and drafted slightly off-scale to avoid overlap with the ITT log. 
Triassic age drilled in the Central North Sea and western Skagerrak. Downwards and distally it grades into the pelitic Smith Bank Formation. In some wells it is seen to be overlain by the Gassum Formation, but commonly it is unconformably overlain by postTriassic series. No fully drilled sections are available within Danish waters (cp. Table 10) and the transition to the Smith Bank Formation is only known from the Dansk Nordsø D-1 well (fig. 19). The sequences drilled in the northern part of Jylland, the Frederikshavn and Skagen wells, and from Skåne (Sweden) known as the Kågeröd Beds are included in the Skagerrak Formation, but palynology indicates that these sequences are of late Triassic age only. The Dansk Nordsø $\mathrm{F}-1$ and $\mathrm{K}-1$ profiles were published in Bertelsen (1975). The northern well sections in Jylland were referred to the Skagerrak Formation by Bertelsen (1978).

\section{Description}

\section{Lateral extension and thickness}

As within Norwegian waters (Deegan \& Scull l.c.), the maximum thickness of the formation may locally exceed $3000 \mathrm{~m}$ based on seismic information. The northern and eastern extension limits are given on the maps (figs. 8, 11, 15). The southern distal limits are indicated by facies change lines whenever possible.

\section{Lithology}

The formation consists mainly of interbedded, redbrown, brown and greyish fine- to medium-grained sandstones, siltstones and claystones. The sandstones are often arkosic, sporadically glauconitic in the upper part of the formation, and generally micaceous. The claystones of the uppermost part of the formation are variegated, red, purple, yellow and green. Thin carbonaceous claystones are encountered locally.

\section{Log motifs and boundary definitions}

The lower boundary towards the Smith Bank Formation is defined by a decrease in the silt/sand content as indicated on the gamma ray - ITT log or other adequate logs. The upper boundary is generally marked by the disappearance of red colours.

The log motifs of the gamma ray or SP logs may be indicative of rather monotoneous sandy sequences with weak upward fining tendencies in the individual cycles (fig. 20 and Dansk Nordsø $\mathrm{K}-1$ in Bertelsen 1975 , text-fig. 2) or they may show coarse inter- bedding of sand with "cylindrical" to "bell-shaped" patterns and claystone (Vedsted 1, Flyvbjerg 1, Frederikshavn 2 in Bertelsen 1978, fig. 8).

\section{Geological age}

Based on comparison with the "transitional" wells Mors 1, Gassum 1 and Rønde 1 it is thought that the Skagerrak Formation in the Danish Subbasin when fully developed is Scythian to Norian in age. Palynological investigations in the Dansk Nordsø F-1 well (Bertelsen 1975) indicate, that this reference section is late Ladinian or younger in age.

\section{Interpretation of the depositional history}

The sediment characters and the log motifs of the Skagerrak Formation so far known in the Danish area seem to point towards sedimentary environments of a continental plain with deposition mainly from braided streams (?wadis) during the early - mid Triassic. During the late Triassic increased subsidence rate (see Oddesund Formation, p. 37) is thought to have changed the sedimentary conditions in the following way. The basin of sedimentation is expanding to its maximum size, thus overstepping the Fennoscandian Border Zone as seen in northern Jylland and in Skåne and a hypersaline sea was formed in the center of the Danish Subbasin. This event combined with periods of low humidity may have caused a displacement of the Skagerrak Formation facies belt towards the north and east and may explain the claystone mixed arkosic facies recognized in the upper part of the formation. The occurrence of glauconite in the upper part of the formation may be due to minor floodings of the marginal areas during the deposition of either the Oddesund Formation or the Vinding Formation during the Carnian - Norianearly Rhaetian time.

\section{The Central Graben Facies Province}

The Central Graben Facies Province comprises the fault-bounded area situated between the Mid North Sea High to the west and the East North Sea Block of the Ringkøbing - Fyn High to the east. A NNW-SSE trending structural high - the Dogger High - divides the area into two subareas of approximately equal size of which the eastern one makes up the major part of the Danish Central Graben sector.

The extension of the Triassic within the Central Graben area is most likely fault-controlled, and Triassic deposits are believed to be absent or thin on 
the surrounding blocks of the Mid North Sea High and the Ringkøbing - Fyn High, as well as on the Dogger High. Maximum thicknesses of $\pm 2000 \mathrm{~m}$ seem to be confined to the southeastern part of the area (fig. 3) which was also strongly subsiding during the Jurassic. In the northern part of the area, which falls within the North Sea Tertiary depocenter the post-Triassic sedimentary overburden severely obscures the seismic reconnaisence of the Triassic. Well control is limited to the southern part, but the most complete well sections are still un-released for publication, thus only reference sections for the younger part of the Triassic deposits are shown.

The lithology met in the Central Graben area is very similar to that described in the Southern North Sea Basin by Geiger \& Hopping (1968), Rhys (1974) and Brennand (1975). The Triassic deposits have therefore been lithostratigraphically divided in accordance with the principles and the nomenclature proposed by Rhys (1974) for the Southern North Sea Basin (see fig. 7, p. 13). It must, however, be stressed, that a more concise form of the formation names introduced by Rhys seems necessary to make them acceptable for common lithostratigraphic nomenclature practice. For instance the Triton Anhydritic Formation should preferably be named the Triton Formation etc.

The four depositional megacycles recognized in the Germano-type Facies Province are also found in the Central Graben sequence. The first, regressive cycle corresponds to the Bacton Group. The second, transgressive cycle corresponds to the Dowsing Dolomitic Formation (Röt and Muschelkalk transgressions). The third cycle is regressive and is represented by the Dudgeon Saliferous Formation and the Triton Anhydritic Formation. The fourth cycle is transgressive and corresponds to the Winterton Formation.

\section{Bacton Group Rhys 1974}

Type section. See p. 14.

Reference section. No releasable section available.

Remarks. The basal part of the Bacton Group is probably drilled in the $\mathrm{B}-1 \mathrm{x}$ well now situated in the German sector, whereas the upper parts are known from unreleased wells.

The sequence consists of mainly reddish, occasionally silty, anhydritic and calcareous claystone with minor silt- and sandstone beds. Thin layers of dolomite may also be present. Due to the general lack of sandstone, it has not been feasable to divide the group into formations as in the Southern North Sea, and the sequence is therefore referred to as the Bunter Shale Formation alone.

No palyno-data are available, but for reasons mentioned earlier (p. 18) the sequence can probably be referred to the Scythian Series (fig. 7). Also the mode of deposition has already been described ( $p$. 18). The low sand content recorded so far is explained by the distal position of the area in relation to the main source areas of the clastics, which are believed to have been to the north. Some material may also have originated in the suggested positive areas of the surrounding structural highs, but as these areas seem to have been exposed to erosion during the late Carboniferous and Permian periods, they were most likely peneplaned and without relief of any importance.

\section{Haisborough Group Rhys 1974}

Remarks. The Haisborough Group is a mainly pelitic unit, which was divided by Rhys (1974) into three formations on the basis of the relative importance of dolomite, halite and anhydrite. These are the Dowsing Dolomitic Formation, the Dudgeon Saliferous Formation and the Triton Anhydritic Formation.

The Danish Central Graben area was only slightly influenced by the so-called Muschelkalk transgressions and stayed in the same marginal position palaeogeographically as did the Southern North Sea Basin (see fig. 14). Therefore the lithostratigraphy proposed for the latter basin is readily applicable to the Danish Central Graben.

\section{Dowsing Dolomitic Formation Rhys 1974}

Type section. (Rhys 1974, fig. 5). Conoco Group 49/21-2 well, U.K. North Sea sector $53^{\circ} 19^{\prime} 00^{\prime \prime} \mathrm{N}-02^{\circ} 05^{\prime} 45^{\prime \prime} \mathrm{E}$

\section{Depth interval \\ $1127 \mathrm{~m}-1219 \mathrm{~m}$ below M.S.L. $3800^{\prime}-4103^{\prime}$ below K.B. $(\mathrm{GR}+\mathrm{ITT} / \mathrm{GR}+\mathrm{ITT})$}

Thickness in type section: $92 \mathrm{~m}$

Reference section. No releasable section available.

Remarks. The upper part of the formation was penetrated by the drilling of the A-2x well, but unfortunately no wire line logs were run in the formation. 
The formation consists of variegated dark reddish brown, grey and grey-green, calcareous (dolomitic) claystone, with two members of halite, surrounded by and with thin interbeds of light grey to greenish grey marlstone/claystone, and anhydrite. Subordinate siltstone beds may occur. The halite members grade laterally into marlstone, anhydrite and calcareous, grey claystone.

The base of the formation is in the Danish area defined as the base of the lower halite member, the Röt Halite, or equivalent beds. The boundary thus corresponds to the base of the Ørslev Formation in the Germano-type Facies Province. Rhys (1974) includes a thin claystone bed below the Röt Halite in the Dowsing Dolomitic Formation and the above definition is therefore slightly different from the one originally proposed.

The upper boundary of the formation is indistinct and is based mainly on changes in the carbonate content.

The upper halite member has been dated to Anisian by means of palynology in the $A-2 x$ well (Bertelsen 1975).

The depositional history of the southern megabasin discussed earlier (see Ørslev and Falster Formations, p. 25 and p. 28., and the map, fig. 11).

The Dowsing Dolomitic Formation has hitherto only been drilled in the southern part of the area and the northern limit is therefore unknown. Recorded facies changes in the halite members towards marly/ anhydritic equivalent beds suggest limitation of the northern outliers of the 'Röt' and 'Muschelkalk' salt to the Triassic depocenter as indicated by the map fig. 11 .

\section{Dudgeon Saliferous Formation Rhys 1974}

Type section. (Rhys 1974, fig. 5). Conoco Group 49/21-2 well, U.K. North Sea sector $53^{\circ} 19^{\prime} 00^{\prime \prime} \mathrm{N}-02^{\circ} 05^{\prime} 45^{\prime \prime} \mathrm{E}$

Depth interval

$850 \mathrm{~m}-1127 \mathrm{~m}$ below M.S.L.

$2790^{\prime}-3697^{\prime}$ below K.B.

$(\mathrm{GR}+\mathrm{ITT} / \mathrm{GR}+\mathrm{ITT})$

Thickness in type section: $276 \mathrm{~m}$

\section{Reference section. (fig. 21). Dansk Nordsø O-1x well} $55^{\circ} 22^{\prime} 02^{\prime \prime} \mathrm{N}-05^{\circ} 19^{\prime} 19^{\prime \prime} \mathrm{E}$

\section{Depth interval \\ $3384 \mathrm{~m}-3550 \mathrm{~m}$ below M.S.L. \\ $11193^{\prime}-11740^{\prime}$ below K.B.}

Thickness in reference section: $167 \mathrm{~m}+$

Remarks. The formation is not fully penetrated in the reference well, but most of the characteristic of the formation can be illustrated by means of the chosen section.

The Dudgeon Saliferous Formation was defined by Rhys (1974) in the Southern North Sea Basin to comprise the halite bearing claystone sequence found between the dolomitic claystone of the Dowsing Dolomitic Formation below, and the mainly anhydritic claystone of the Triton Anhydritic Formation above. The lithological development of the Danish area during the mid and late Triassic is comparable to that of the Southern North Sea, and the formation. name of Rhys (1974) has also been adopted for this sequence.

\section{Description}

Lateral extension and thickness

The formation has previously only been drilled in the southern depocenter area (see map fig. 15). The maximum recorded thickness is ca. 280 metres (table 9).

\section{Lithology}

The formation consists of, in part silty, dark reddish brown, brick-red, and grey-green, calcareous and sporadically anhydritic claystone. A prominent halite member (fig. 15) is present in the $0-1 \mathrm{x}$ well, whereas equivalent deposits of mainly grey coloured marlstone, dolomite and anhydrite are encountered in a non-released more marginal positioned well.

\section{Log motifs and boundary definitions}

The lower boundary is indistinct. In the type well and in an unreleased reference profile of the Danish area it is defined by means of the gamma ray - ITT $\log$. In both wells the lower part of the formation shows slightly higher radioactivity and interval transit time values than the underlying Dowsing Dolomitic Formation, probably due to differences in the carbonate content of the two formations.

The upper boundary is in the type profile (Rhys 1974, fig. 5) and in the Danish reference section de-

\footnotetext{
Fig. 21. Dansk Nordsø O-1. Reference sections of the Dudgeon Saliferous Formation, the Triton Anhydritic Formation and the Winterton
} Formation. For Legend see fig. 9. 


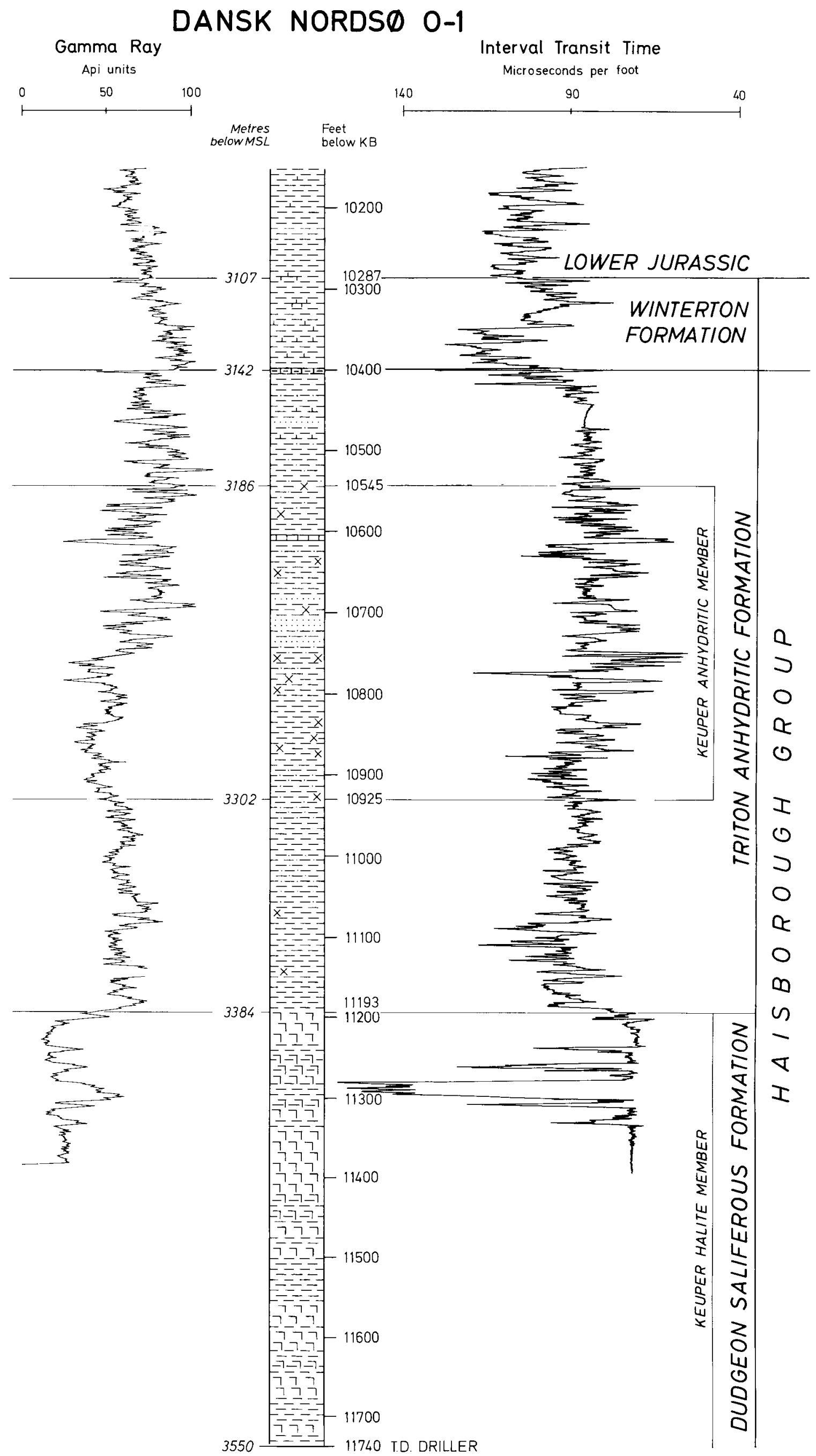


fined as the top of the Keuper Halite Member, which is easily recognizable on the gamma ray - ITT log (fig. 21). In other wells with imperfectly developed or missing halite beds the upper boundary is set on the ITT $\log$ at a curve shift point from low ITT values below to higher ITT values above.

The log motifs of the Dudgeon Saliferous Formation are irregular due to the variable evaporite and carbonate content.

\section{Geological age}

Miospores recovered from the salt clay of the reference well indicate a Carnian age for the Keuper $\mathrm{Ha}$ lite Member in the Danish Central Graben (Bertelsen 1975).

\section{Interpretation of the depositional history}

The formation is comparable, if not identical, with the lower part of the Oddesund Formation (p. 33) and is suggested to have been deposited in environments similar to those existing in the Danish Subbasin in the same period, that is in a mainly continental sabkha. As in the Danish Subbasin the more soluble salts are precipitated in the basin center, whereas the less soluble sulphates and carbonates are found in fringing facies belts.

The Keuper Halites are generally more restricted in lateral extension than the former Röt and Muschelkalk Halites in the southern megabasin, with the exception of the Polish Basin, where none of the older Halites were precipitated.

The Dudgeon Saliferous Formation represents the older deposits of the third, regressive Triassic megaphase.

\section{Triton Anhydritic Formation Rhys 1974}

Type section. (Rhys 1974, fig. 5) Conoco Group 49/21-2 well, U.K. North Sea sector $53^{\circ} 19^{\prime} 00^{\prime \prime} \mathrm{N}-02^{\circ} 05^{\prime} 45^{\prime \prime} \mathrm{E}$

$$
\begin{aligned}
& \text { Depth interval } \\
& 636 \mathrm{~m}-850 \mathrm{~m} \text { below M.S.L. } \\
& 2191^{\prime}-2893^{\prime} \text { below K.B. } \\
& \text { (GR+ITT/GR+ITT) }
\end{aligned}
$$

Thickness in type section: $214 \mathrm{~m}$

Reference section. (fig. 21). Dansk Nordsø O-1x well $55^{\circ} 22^{\prime} 02^{\prime \prime} \mathrm{N}-05^{\circ} 19^{\prime} 19^{\prime \prime} \mathrm{E}$

Depth interval

$3142 \mathrm{~m}-3384 \mathrm{~m}$ below M.S.L.

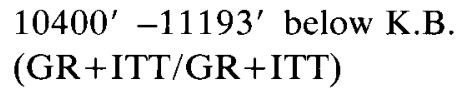

Thickness in reference section: $242 \mathrm{~m}$

Remarks. The Triton Anhydritic Formation was proposed by Rhys (1974) for the uppermost, anhydrite bearing part of the Triassic red bed sequence of the Southern North Sea Basin. The formation is recognizable without any difficulties in the Danish sector.

\section{Description}

\section{Lateral extension and thickness}

The recorded thickness of the formation varies from approximately $230 \mathrm{~m}$ to $280 \mathrm{~m}$ (table 9 ). The formation is only known from the southern depocenter area (see map fig. 15).

\section{Lithology}

A threefold division of the formation can be made, with a lower section of dark reddish brown and grey-green, slightly calcareous to non-calcareous, micaceous claystone with some anhydrite, a middle section of grey to reddish brown variegated or brick-red, rarely grey-green, calcareous and anhydrite bearing claystone, with some siltstone and marlstone intercalations, and an upper section of calcareous, light grey, greenish grey, grey-red, brown-red and lavender marlstone and claystone.

The middle section constitutes the Keuper Anhydritic Member, which due to the presence of anhydrite shows a distinct log response.

\section{Log motifs and boundary definitions}

The boundary with the Dudgeon Saliferous Formation is not very distinct as described above. In contrast, the upper boundary with the Winterton Formation is readily fixed by means of a gamma ray ITT $\log$ (see fig. 21). The basal claystone of the Winterton Formation is seen as a rather abrupt increase of the gamma ray and interval transit time readings.

The middle Keuper Anhydritic Member is characterized by many, distinct peak motifs on the ITT, the density and the resistivity logs corresponding to the individual anhydrite layers.

\section{Geological age}

No palynomorph or other microfossils have so far been recovered from the formation in the Danish sector. It is however reasonable to compare the for- 
mation with the upper part of the Oddesund Formation (the Keuper Anhydritic Member is thought to correspond to the Upper Evaporitic Beds of the latter), which means that the Triton Anhydritic Formation was deposited during the Carnian - early Norian.

\section{Interpretation of the depositional history}

The Triton Anhydritic Formation was probably deposited during the third, regressive Triassic megacycle in the same way as the Oddesund Formation, which is discussed on p. 36. The predominant environment seems to have changed from distal floodplain through continental/coastal sabkha to distal flood plain.

\section{Winterton Formation Rhys 1974}

Type section. (Rhys 1974, fig. 5). Conoco Group 49/21-2 well, U.K. North Sea sector

$$
\begin{aligned}
& 53^{\circ} 19^{\prime} 00^{\prime \prime} \mathrm{N}-02^{\circ} 05^{\prime} 45^{\prime \prime} \mathrm{E} \\
& \text { Depth interval } \\
& 561 \mathrm{~m}-636 \mathrm{~m} \text { below M.S.L. } \\
& 1943^{\prime}-2191^{\prime} \text { below K.B. } \\
& (\mathrm{GR}+\mathrm{ITT} / \mathrm{GR}+\mathrm{ITT})
\end{aligned}
$$

Thickness in type section: $76 \mathrm{~m}$

Reference section. (fig. 21) Dansk Nordsø O-1x well $55^{\circ} 22^{\prime} 02^{\prime \prime} \mathrm{N}-05^{\circ} 19^{\prime} 19^{\prime \prime} \mathrm{E}$

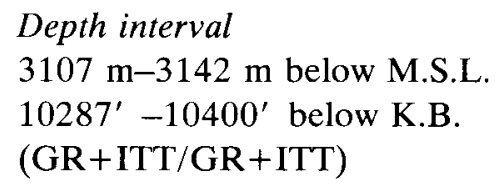

Thickness in reference section: $34 \mathrm{~m}$

Remarks. The Rhaetic Sandstone Member recognized in the Southern North Sea Basin (Rhys 1974) is not present in the Danish wells. Further, it should be mentioned, that the claystone of the Winterton Formation is described as non-calcareous in contrast to the claystone of the Danish area. The correlation with the Winterton Formation and the adoption of the name is therefore tentative. It is possible, that the Danish unit only represents the lower part of the Winterton Formation, and that early Cimmerian uplift of the area caused reduction of the sequence. In the reference well, the $\mathrm{O}-1 \mathrm{x}$ well, the unit is overlain by a Lower Jurassic, marine claystone formation comparable to the Fjerritslev Formation of the Nor- wegian - Danish Basin of which the basal member is of definite Hettangian age proven by ostracods (Michelsen, 1978 b).

\section{Description}

\section{Lateral extension and thickness}

The recorded thickness of the formation is less than $40 \mathrm{~m}$ (table 9). The lateral extension is probably restricted to the southern depocenter area and coincides reasonably with the extension of the Haisborough Group.

\section{Lithology}

The formation is composed of, dark grey, brownish and greenish, calcareous claystone interbedded with minor beds of marlstone.

\section{Log motifs and boundary definitions}

Both the lower and the upper boundary are well marked on the gamma ray - ITT log as a change from low values below to high values above the boundary. This is due to a bipartition of the formation in a lower part of relatively pure claystone and an upper part with marlstone stringers (see fig. 21). This means, that the $\log$ motifs of the upper part compare with those of the underlying Triton Anhydritic Formation, whereas the log motifs of the lower part resemble those of the overlying Jurassic claystone.

\section{Geological age}

In the reference well an ostracod assemblage of $\mathrm{Em}$ phasia spp. in ditch sample $10390^{\prime}-10400^{\prime}$ b. K.B. is indicative of a Rhaetian age (Michelsen, 1978b), which to some extent is confirmed by the presence of Ricciisporites tuberculatus miospores. Sidewall cores prepared for palynology in other wells have hitherto been barren and the occurrence of $R$. tuberculatus in the $\mathrm{O}-1 \mathrm{x}$ well may therefore be caused by caving of the Hettangian claystone.

The lithology and the occurrence of Emphasia spp. may justify a correlation of the formation with the Vinding Formation of the Danish Subbasin (see p. 37).

\section{Interpretation of the depositional history}

The lithology as well as the palaeontological record shows that the deposition of the formation in the Danish area took place in slightly oxidizing environments. The Rhaetian transgression which in the Danish Subbasin gave rise to the deposition of the fossiliferous Vinding Formation (Bertelsen 1978), and which marked the beginning of the fourth, transgressive Triassic megacycle seems only to have 
weakly influenced the Central Graben area unless, of course, more typically brackish-marine deposits are missing in the sequence due to early Cimmerian erosion.

The deposits are interpreted as being formed in low energy, super- to intertidal, marsh-like environments.

\section{Acknowledgements}

The author wishes to thank dr.phil. Leif Banke Rasmussen, Head of the Department for Subsurface Geology (D.G.U.), for his encouragement and for permission to publish the results.

Special thanks are given to my colleagues dr.phil. Olaf Michelsen and cand.scient. Søren Priisholm for reading the manuscript and for valuable criticism and discussions.

I am grateful to Ms. Eva Melskens and Ms. Kirsten Andersen for careful drawing of the illustrations.

\section{Dansk sammendrag}

\section{De danske trias-aflejringers lithostratigrafi og aflejringshistorie}

\begin{abstract}
Afhandlingen er et forsøg på at give en sammenfattende beskrivelse af de danske trias-aflejringer med hovedvægt på en moderne formationsinddeling, samt ud fra sedimenternes karakter og rumlige fordeling at skitsere bassinudviklingen gennem trias perioden. Arbejdet, der har karakter af en status rapport, er inspireret af nedsættelsen af stratigrafiske sub-kommissioner for de enkelte geologiske systemer i 1975, herunder dannelsen af en præ-jurassisk subkommission, samt fremkomsten af regionale lithostratigrafiske inddelingsforslag for dels det Sydlige Nordsø Bassin (Rhys 1974), dels for den Centrale og Nordlige Nordsø (Deegan \& Scull 1977).

Efter en historisk oversigt, hvoraf det fremgår, at en germansk præget terminologi har været fremherskende ved trias inddelingen, gives en generel sammenfatning af trias sedimenternes tykkelse og udbredelse, samt hvilke lagserier de hviler på og dækkes af. Den samlede mægtighed overstiger $1000 \mathrm{~m}$ i størstedelen af bassinerne, det Norskdanske Bassin og den nordlige rand af det Nordtyske Bassin, samt de gravsænkninger eller trug der $\mathbf{i}$ nord-sydlig retning gennemskærer Ringkøbing - Fyn Højderyggen og forbinder de to bassiner. I den cen-
\end{abstract}

trale del af det Danske Subbassin, der udgør den østlige del af det Norsk-danske Bassin, er påvist (seismisk) særdeles store mægtigheder, mere end $5000 \mathrm{~m}$, ligesom også den sydvestlige del af Horns Truget har betydelig trias mægtighed, mere end 3000 m. Triaslagene overlejrer øvre perm (zechstein) evaporitserien konformt $\mathrm{i}$ bassinerne, medens man $\mathrm{i}$ randzonerne finder trias på grundfjeld (prækambrium), på ordovicium-silur eller på nedre perm (rotliegendes). De overlejrende lag udgøres centralt $\mathrm{i}$ bassinerne af nedre jurrassiske lersten, Fjerritslev Formationen eller ækvivalente nordtyske lag. Langs den nordlige og østlige rand af det Danske Subbassin fortsatte sandstenssedimentationen ind i nedre jura og top trias fastlægges derfor biostratigrafisk i denne randzone. Langs Ringkøbing-Fyn Højderyggen er triaslagene eroderede som følge af Midt-Cimmerisk (i mellem jura) hævning. De overlejrende lag er her af øvre jurassisk - nedre kretasisk alder.

Det følgende hovedafsnit er viet en lithostratigrafisk oversigt og inddeling af trias lagene inden for tre sedimentations områder, den Germanotype Facies Provins, den Nordlige Marginale Facies Provins samt Central Graben Facies Provinsen. Inden for hver facies provins er lagserien inddelt $\mathrm{i}$ formationer og grupper på baggrund af »wire line « log korrelationer og lithologiske beskrivelser. For hver formation er udvalgt type- eller reference profiler i relevante boringer, ligesom grænsedefinitioner, lithologi, log motiver, geologisk alder og bassinudvikling er beskrevet. En oversigt over de opstillede enheder er vist på fig. 7. (p. 13).

Den Germanotype Facies Provins omfatter den nordlige del af det Nordtyske Bassin, Ringkøbing Fyn Højderyggens område, samt den sydlige og centrale del af det Danske Subbassin. Indenfor dette område er trias-lagserien sammenlignelig med de jævnaldrende lagserier $i$ det Nordtyske Bassin og $i$ det Polske Bassin.

Lagserien inddeles i fire grupper, hvoraf de tre yngste er nye og hver gruppe underinddeles $i$ to formationer, hvoraf fire er nye. Gruppeinddelingen modsvarer bassinudviklingen, der kan sammenfattes i fire sedimentationsfaser - regression - transgression - regression - transgression.

Bacton Gruppen (Rhys 1974) er den ældste gruppe, der underinddeles i en nedre lerstens formation, Bunter Shale, og en øvre sandstensførende formation, Bunter Sandstone, begge opstillet af Rhys (1974). Udbredelse, mægtigheder og referenceprofiler er gengivet på figs. 8-10. Aflejringerne består af rødligt farvede, anhydrit- og siltholdige lersten, siltsten og sandsten, der må tænkes afsat på enorme, flade kyst- og flodsletter under meget tørre og varme 
klimatiske betingelser. Periodiske overskylninger fra et sydligt beliggende brakvandshav har givet ophav til oolithiske dannelser, Rogenstein, der er påvist i de sydligste boringer. Gruppens aflejringer afspejler den generelle regression, der fulgte den marine øvre permiske Zechstein fase i Nordvesteuropa. Tilsvarende aflejringer i det Nordtyske Bassin er henført til de nedre triassiske etager Brahmanian, Jakutian og tidlig Olenekian.

Lolland Gruppen (ny) er den følgende gruppe, der deles i en nedre Ørslev Formation (ny), tidligere benævnt Röt, og en øvre Falster Formation (ny), tidligere benævnt Muschelkalk. Ørslev Formationen består af en nedre evaporitrig del og en øvre lerstensrig del, hvoraf den øvre del minder meget om Bunter Shale. Falster Formationen udgøres hovedsageligt af grå og grågrønne lersten, mergelsten og kalksten, ofte dolomitiske. Den midterste del af formationen er ofte rødligt broget med anhydritiske indslag, ligesom sporadiske sandsten er observeret. Udbredelse, mægtigheder og referenceprofiler er vist på figs. 11-14. Lolland Gruppens formationer er dannet $\mathrm{i}$ den anden, transgressive, triassiske hovedfase. Det nordvesteuropæiske epikontinentale område påvirkes i denne fase af det sydligt beliggende Tethys ocean, der via stadigt skiftende forbindelsesveje tilfører bassinerne havvand og marine faunaer (fig. 14). Den nedre del af Falster Formationen modsvarer en periode med maximal havudbredelse, hvor også Ringkøbing - Fyn Højderyggen har været overskyllet, jfr. Glamsbjerg 1 profilet. I perioder med ringe ferskvandstilførsel til bassinerne og høj ariditet er stensalt udfældet af overmættede saltopløsninger i bassinernes centrale dele, således også i det Nordtyske Bassin og i Horns Truget (fig. 11). Klimaet synes som i den foregående fase at have været varmt og tørt, aridt til semiaridt. Gruppen kan aldersmæssigt henføres til ?sen Olenikian - Anisian - tidlig Ladinian, såfremt dannelserne jævnføres med lagserien i det Nordtyske Bassin.

Jylland Gruppen (ny) inddeles i en nedre, sandstensførende, lerstensformation, Tønder Formationen (ny), samt en øvre lerstensformation karakteriseret af to inddampningsserier, Oddesund Formationen (ny). Lerfarverne er i begge formationer rødlige, brunlige, grålige og grønlige. I Tønder Formationen er sandstenslagene mest hyppige i den øvre del. I Oddesund Formationen er inddampningsserierne udviklet som mægtige stensaltslag i den centrale og dybe del af det Danske Subbassin, medens anhydritrige lersten er dannet i randområderne. I den sydøstlige del af det Danske Subbassin er gruppen repræsenteret ved overvejende grålige mergelsten og lersten, der indtil videre uformelt er betegnet Ringe
Beds. Jylland Gruppen er aflejret i den tredje, regressive triassiske hovedfase, hvor indflydelsen fra Tethys er stærkt mindsket i de epikontinentale bassiner. Klimasvingninger og tektonisk ustabilitet præger fasen. I perioder med forøget nedbør udbygges deltasystemer i bassinerne, i Tyskland aflejres således Lettenkohlensandstein (svarende til sandstenslagene i Tønder Formationen) og Schilfsandstein. I tørre perioder udfældes derimod anhydrit og stensalt, sidstnæunte i de dybe dele af bassinerne. Indsynkningshastigheden i det Danske Subbassin har været meget stor i denne fase, hvilket er blevet modsvaret af en betydelig sedimentation, der igen i samspil med forkastningsdannelser har udløst halokinese i det underliggende perm salt. Den begyndende pudedannelse af Zechstein saltet $\mathrm{i}$ denne fase kan eftervises seismisk og seismogrammer fra den centrale del af det Danske Subbassin illustrerer tydeligt, hvordan saltkoncentration og salttilbagetrækning har influeret på sedimentationsforløbet jfr. det generelle trias mægtighedskort (fig. 3). Jylland Gruppens udbredelse, mægtighed og type/referenceprofiler er gengivet på figs. 15-17. Gruppens aflejringer kan henføres til sen Ladinian - Carnian - tidlig Norian.

Mors Gruppen (ny) omfatter Vinding Formationen og Gassum Formationen oprindeligt opstillede af Larsen (1966), men senere genbeskrevne, reviderede og kortlagte af forfatteren (Bertelsen 1978). Gruppen, der er karakteriseret af overvejende grå lerfarver, blev aflejret i den sidste, transgressive triassiske hovedfase, hvorunder et lavvandet brakvandshav indvaderede området. I begyndelsen aflejredes hovedsageligt lersten og tynde, stedvist oolithiske kalksten (Vinding Formationen), senere ved overgangen trias - jura fluvio-deltaiske sandsten (Gassum Formationen). Den markante udbygning af deltasystemerne på denne tid er sat $\mathrm{i}$ forbindelse med dels en generel regression som følge af tidlig Cimmeriske hævninger, der kan spores i den Fennoscandiske Randzone, dels en betydelig forøgelse af klimaets humiditet, der kommer til udtryk i plantefossilindholdet. Under den følgende nedre jurassiske transgression rykker deltafronten (kystlinien) gradvist tilbage mod den nordlige og østlige bassinrand og Gassum Formationens yngste lag er derfor i randzonen af jurassisk alder (Hettangian - Sinemurian). I bassinmidten og den sydlige del af området kan Mors Gruppen henføres til sen Norian - Rhaetian. Kortet, fig. 18, viser mægtighed og udbredelse af den triassiske del af Mors Gruppen.

Den Nordlige Marginale Facies Provins omfatter den nordvestlige, nordlige og østlige randzone af det Danske Subbassin, ligesom den norske del af det Norsk-danske Bassin helt synes at kunne inkluderes i 
denne provins. Overgangszonen til den Germano-type Facies Provins forløber gennem den centrale del af det Danske Subbassin, som angivet ved »facies change lines « på distributionskortene for de enkelte grupper. Tidsstratigrafisk omfatter provinsen de prærhætiske triasaflejringer.

Deegan \& Scull (1977) sammenfatter disse aflejringer i en uformel »Triassic group «, bestående af en nedre og distal lerstensformation, Smith Bank Formation, og en øvre og proximal silt/sandstensformation, Skagerrak Formation. Begge formationer må stort set opfattes som fluviatile, kontinentale dannelser sedimenteret i oxiderende miljøer. Den øverste del af Skagerrak Formationen bærer dog vidnesbyrd om kortvarige marine indslag i form af glaukonitholdigt sand. Denne del ligestilles tidsmæssigt med dele af Vinding Formationen og de skånske Kågeröd Lag.

Central Graben Facies Provinsen omfatter den danske del af Midtnordsø gravsænkningen betegnet Central Graben. Den lithologiske udvikling i denne provins svarer nøje til udviklingen $i$ det Sydlige Nordsø Bassin som beskrevet af Rhys (1974), med undtagelse af de manglende sandlag i Bacton Gruppen, der derfor ikke kan underinddeles i formationer. Over Bacton Gruppen følger Haisborough Gruppen, der underinddeles i Dowsing Dolomitic Formation, Dudgeon Saliferous Formation og Triton Anhydritic Formation på basis af karbonat og evaporitindhold. Den førstnævnte formation, der rummer et basalt salt member, kan sammenlignes med Lolland Gruppen, men er ikke så markant præget af Muschelkalk-transgressionen som sidstnæunte gruppe. Evaporit-lagene i Dudgeon Saliferous Formation og Triton Anhydritic Formation kan antagelig korreleres med evaporitserierne i Oddesund Formationen og de tre formationer har mange fællestræk og er antagelig dannet $i$ sammenlignelige miljøer. Den yngste formation $i$ området, Winterton Formationen, kan muligvis ligestilles med den nedre del af Vinding Formationen, men er tilsyneladende afsat i mere oxiderende miljø end denne, idet bl. a. pollen og sporer er uhyre sjældne. Winterton Formationen overlejres af basal jurassiske, marine lersten af Hettangian alder og manglen på sandsten svarende til Gassum Formationen kan måske tyde på en sedimentationsafbrydelse i sen trias tid som følge af tidlig Cimmerisk hævning.

\section{Selected bibliography}

Andersen, O. B., Larsen B. \& Platou, S.W., 1975. Gravity and geological structure of the Fennoscandian Border-Zone in the southern Baltic Sea. - Bull. geol. Soc. Denmark, 24, pp. 45-53.

Audley-Charles, M. G., 1970. Stratigraphical correlation of the Triassic rocks of the British Isles. - Q. Jl geol. Soc. Lond., 126, pp. 19-47.

Baartman, J. C. \& Christensen, O. B., 1975. Contributions to the interpretation of the Fennoscandian Border Zone. - Danm. geol. Unders., II rk., 102, 47 pp.

Bertelsen, F., 1975. Triassic palynology and stratigraphy of some Danish North Sea boreholes. - Danm. geol. Unders., Årbog 1974, pp. 17-32.

Bertelsen, F., 1978. The Upper Triassic - Lower Jurassic Vinding and Gassum Formations of the Norwegian - Danish Basin. Danm. geol. Unders., Ser. B., 3, 26 pp.

Bertelsen, F. \& Michelsen, O., 1970. Megaspores and ostracods from the Rhaeto-Liassic section in the boring Rødby No. 1, southern Denmark. - Danm. geol. Unders., II rk., 94, 60 pp.

Bjelm, L., Hartlen, J., Röshoff, K., Bennet, J., Bruch, H., Persson, P-G. \& Wadstein, P., 1977. - Geotermisk energiutvinning i Skåne, slutrapport etapp 1. Rep. published by Tekniska högskolan i Lund, Sweden.

Boigk, H., 1959. Zur Gliederung und Fazies des Buntsandsteins zwischen Harz und Emsland. - Geol. Jb., 76, pp. 597-636.

Boigk, H., 1961. Ergebnisse und Probleme stratigraphischpaläogeographischer Untersuchungen im Buntsandstein Nordwestdeutschlands. - Geol. Jb., 78, pp. 123-134.

Brennand, T. P., 1975. The Triassic of the North Sea. - In: Woodland, A. W. (edit.). Petroleum and the Continental Shelf of Northwest Europe, Vol. I, Geology, pp. 295-311.

Brotzen, F. 1950. De geologiska resultaten från borrningarna vid Höllviken, Del II. Undre Kritan och Trias. - Sver. geol. Unders., Ser. C. No. 505, $48 \mathrm{pp}$

Bölau, E., 1959. Der Südwest- und Südostrand des Baltischen Schildes (Schonen und Ostbaltikum). - Geol. Fören. Förhandl., 81 , pp. $167-230$.

Bölau, E. 1969. Tektonische und klimatische Ausdeutung von Faziesgegensätzen im Rhät Schonens. - Geol. Fören. Förhandl., 91 , pp. 561-573.

Christensen, O. B., 1962. Ostracodtyper fra Keuper-Rhaet lagserien i dybdeboringerne ved Harte og Ullerslev. - Medd. Dansk Geol. Foren., 15, pp. 90-99.

Christensen, O. B., 1963. Ostracoder fra Keuper-Rhaet i nogle danske dybdeboringer. - Medd. Dansk Geol. Foren., 15, p. 240.

Christensen, O. B., 1971. Biostratigrafisk undersøgelse af trias $\mathrm{i}$ Rønde nr. 1 og trias-jura grænseområdet. - Danm. geol. Unders. III rk., 39, pp. 89-93.

Christensen, O. B., 1972. Det danske sænkningsområdes udvikling i det mellemste Mesozoikum. - Dansk geol. Foren., Årsskrift for 1971 , pp. 55-62.

Christensen, O. B., 1973. Vinding formationen (øvre trias) i Nøvling nr. 1. - Danm. geol. Unders., III rk., 40, pp. 132-135.

Czerminskiego, J. \& Pajchlowej, M. (edit.), 1975. Atlas litologiczno-paleogeograficzny obszarow Platformowych Polski 1:2,000,000. Vol. II, Mezozoik (bez Kredy Gorny). Inst. Geol., Warszawa.

Dadlez, R., 1974. Some geological problems of the Southern Baltic Basin. - Acta Geol. Polon., 24, pp. 261-275.

Dadlez, R. (edit.), 1976. Permian and Mesozoic of the Pomerania Trough. - Prace Geol. Inst., 79, 173 pp. (In Polish w/ English resumé.). 
Deegan, C. E. \& Scull, B. J. (compilers), 1977. A proposed standard lithostratigraphic nomenclature for the Central and Northern North Sea. - Rep. Inst. Geol. Sci., No. 77/25.

Diener, I., 1967. Die Paläeogeographie der Kreide im Nordteil der DDR in Beziehung zu den Nachbargebieten. - Ber. deutsch. Ges. geol. Wiss., A, Geol. Paläont., 12, pp. 185-192.

Dinesen, A., 1960. Dybdeboringer på Sjælland, Lavø nr. 1. Medd. Dansk Geol. Foren., 14, p. 280.

Dinesen, A., 1971. Trias i Rønde nr. 1 (2614-4643 m). Lithologisk beskrivelse og inddeling. - Danm. geol. Unders., III rk., 39, pp. 94-107.

Dinesen, A., 1973. Trias i Nøvling, nr. 1 (1847-3423 m). - Danm. geol. Unders., III rk., 40, pp. 136-145.

Erdmann, E., 1872. Beskrifning öfver Skånes Stenkolförande Formation. - Sver. geol. Unders. 87 pp.

Evans, W. B., 1970. The Triassic salt deposits of north-western England. - Q. Jl geol. Soc. Lond., 126, pp. 103-123.

Floden, T., 1973. Notes on the bedrock of the eastern Skagerrak with remarks on the Pleistocene deposits. - Stockh. Contr. Geol., 24, pp. 79-102.

Fuglewicz, R., 1973. Megaspores of the Polish Buntersandstein and their stratigraphical significance. - Acta Palaeont. Polon., 18 , pp. 401-453.

Fuglewicz, R., 1977a. Stratigraphy of the Bunter in the SW margin of the Fore-Sudetic Monocline. - Acta Geol. Polon., 27, pp. 471-479. (In Polish w/ English résumé).

Fuglewicz, R., 1977b. New species of megaspores from the Trias of Poland. - Acta Palaeont. Polon., 22, pp. 405-431.

Gajewska, I., 1973. Description of Reed-sandstone deposits in the Polish Lowland area. - Kwart. Geol., 17, pp. 507-515. (In Polish w/English résumé.).

Geiger, M. E. \& Hopping, C. A., 1968. Triassic stratigraphy of the Southern North Sea Basin. - Phil. Trans. R. Soc., Ser. B., 254, pp. $1-36$.

Glennie, K. W., 1970. Desert sedimentary environments. - Developments in sedimentology, 14, 222 pp. - Elsevier Publ. Comp., Amsterdam.

Gry, H., 1969. Megaspores from the Jurassic of the Island of Bornholm, Denmark. - Medd. Dansk Geol. Foren., 19, pp. $69-89$.

Häusser, I. \& Kurze, M., 1975. Sedimentationsbedingungen und Schwermineralführung im Mesozoikum des Nordteils der DDR. - Z. geol. Wiss., 3, pp. 1317-1332.

Hermann, A., 1962. Epeirogene Bewegungen im germanischen Buntsandsteinbecken und deren Bedeutung für lithostratigraphische Parallelisierungen zwischen Nord- und Süddeutschland. - Geol. Jb., 81, pp. 11-72.

Hiltermann, H. \& Mädler, K., 1977. Charophyten als palökologische Indikatoren und ihr Vorkommen in den Sinterkalken von Bad Laer. - Paläont. Z., 51, pp. 135-144.

Hoppe, W., 1976. Zur Bildungsgeschichte des Buntsandsteins im Germanischen Buntsandsteinbecken. - Z. geol. Wiss., 4, pp. 1457-1471.

Horn af Rantzien, H., 1953. De geologiska resultaten från borrningarna vid Höllviken, Del VI: Charophyta from the Middle Trias of the boring. - Sver. geol. Unders., Ser. C., No. 533, 16 pp.

Horn af Rantzien, H., 1954. Middle Triassic Charophyta of South Sweden. Opera Botanica, 1(2), $80 \mathrm{pp}$.

Kannegieser, E. \& Kozur, H., 1972. Zur Mikropaläontologie des Schilfsandsteins (Karn). - Geologie, Jhg. 21 (2), pp. 185215.

Kendall, A. C., 1978. Facies Models 11. Continental and supratidal (sabkha) evaporites. - Geosci. Canada, 5, pp. 66-78.
Kendall, A. C., 1978. Facies Models 12. Subaqueous evaporites. Geosci. Canada, 5, pp. 124-139.

Kozur, H., 1974a, b. Die Biostratigraphie der germanischen Trias. Teil I. Freiberger Forsch. - H. C 280, pp. 1-56. Teil II. Freiberger Forsch. - H. C. 280, pp. 1-70.

Kozur, H., 1974c. Probleme der Triasgliederung und Parallelisierung der germanischen und tethyalen Trias. - Teil I: Abgrenzung und Gliederung der Trias. - Freiberger Forsch. - H. C 298, pp. 139-197.

Kozur, H., 1975. Probleme der Triasgliederung und Parallelisierung der germanischen und tethyalen Trias. - Teil II: Anschluss der germanischen Trias an die internationale Triasgliederung. - Freiburger Forsch. - H. C 304, pp. 51-77.

Kozur, H. \& Reinhardt, P., 1969. Charophyten aus dem Muschelkalk und dem Unteren Keuper Mecklenburgs und Thüringens. Monatsber. deutsch. Akad. Wiss. Berlin, 11, pp. 369-386.

Larsen, G. 1964: Rhaetic - Jurassic - Lower Cretaceous Sediments from deep wells in North Jylland, Denmark. - In: van Straaten, L. M. J. U. (ed.) 1964: Deltaic and shallow marine deposits. - Devs Sedimentol., pp. 227-235.

Larsen, G., 1966. Rhaetic-Jurassic-Lower Cretaceous sediments in the Danish Embayment (A heavy mineral study). - Danm. geol. Unders., II rk., 91, 127 pp.

Larsen, G. \& Buch, A., 1960. Dybdeboringer på Sjælland, Slagelse nr. 1. - Medd. Dansk Geol. Foren., 14, p. 281.

Larsen, G. \& Friis, H., 1975. Triassic heavy-mineral associations in Denmark. - Danm. geol. Unders., Årbog 1974, pp. 33-47.

Lohmann, H., 1960. Zur Stratigraphie und Fossilführung des Buntsandsteins in Niederhessen. - Mitt. Geol. Staatsinst. Hamburg, 29, pp. 66-84.

Lund, J. J., 1977. Rhaetic to Lower Liassic palynology of the onshore southeastern North Sea Basin. - Danm. geol. Unders., II rk., 109, $129 \mathrm{pp}$

Michelsen, O., 1973. On Liassic holothurian and ostracod assemblages from the Danish Embayment. - Danm, geol. Unders., Årbog 1972, pp. 49-68.

Michelsen, O., 1975. Lower Jurassic biostratigraphy and ostracods of the Danish Embayment. - Danm. geol. Unders., II rk., 104, $287 \mathrm{pp}$.

Michelsen, O., 1976. Kortfattet oversigt over de geologiske forhold i den danske del af Nordsøen. - Danm. geol. Unders., Årbog 1975, pp. 105-116.

Michelsen, O., 1978a. Stratigraphy and distribution of Jurassic deposits of the Norwegian-Danish Basin. - Danm. geol. Unders., Ser. B., No. 2, 29 pp.

Michelsen, O., 1978b. The Lower Jurassic of the Dansk Nordsø O-1 boring, Central Trough. - Danm. geol. Unders., Årbog 1977, pp. 77-78.

Mostler, H. \& Scheuring, B. W., 1974. Microfloren aus dem Langobard und Cordevol der Nördlichen Kalkalpen und das Problem des Beginns der Keupersedimentation im Germanischen Raum. - Geol. Paläont. Mitt. Innsbruck, 4, (4), pp. 1-35.

Norling, E., 1976. Berggrunden. - In: Beskrivningen till jordartskartan Malmö NV. Sver. geol. Unders., Ser. Ae, 27, pp. 3-11.

Norling, E., 1977. Berggrund. - In: Beskrivningen till jordartskartan Höganäs NO/Helsingborg NV. - Sver. geol. Unders., Ser. Ae, 25, pp. 19-32.

Ortlam, D., 1969. Fossile Böden im rechtrheinischen, höheren Buntsandstein, ihre Ursache, Entstehung und stratigraphische Bedeutung. - Z. deutsch. geol. Ges., 118, pp. 238-239.

Orlowska-Zwolinska, T., 1976. Palynological characteristics of the Reed Sandstone in the Polish Lowland area. - Acta Geol. Polon., 26, pp. 557-567.

Orlowska-Zwolinska, T., 1977. Palynological correlation of the 
Bunter and Muschelkalk in selected profiles from Western Poland. - Acta Geol. Polon., 27, pp. 417-430.

Pattison, J., Smith, D. B. \& Warrington, G., 1973. A review of late Permian and early Triassic biostratigraphy in the British Isles. In: Logan, A. \& Hills, L. V. (eds.). The Permian and Triassic systems and their mutual boundary. - Can. Soc. Petrol. Geologists Mem., 2, pp. 220-260.

Ramberg, I. B. \& Spjeldnæs, N., 1978. The tectonic history of the Oslo Graben. In: Ramberg, I. B. \& Neumann, E.-R. (eds.): Tectonics and geophysics of continental rifts, pp. 167-194. D. Reidel Publ. Comp., Dordrecht, Holland.

Rasmussen, L. B., 1974. Some geological results from the first five Danish exploration wells in the North Sea. Dansk Nordsø A-1, A-2, B-1, C-1, and D-1. - Danm. geol. Unders., III Rk., 42, $46 \mathrm{pp}$.

Rasmussen, L. B., 1978. Geological aspects of the Danish North Sea sector. With a report on the wells Dansk Nordsø E-1, E-2, F-1, G-1, H-1, I-1, J-1, and K-1. - Danm. geol. Unders., III Rk., 44, 85 pp.

Rhys, G. H. 1974: A proposed standard lithostratigraphic nomenclature for the southern North Sea and an outline structural nomenclature for the whole of the (UK) North Sea. - Inst. geol. Sc., Report 74/8, 14 p.

Ricour, J., 1962. Contribution à une révision du Trias Francais. Mem. Carte géol Fr., 471 pp.

Rusitzka, D., 1967. Paläogeographie der Trias im Nordteil der DDR. - Ber. deutsch. Ges. geol. Wiss., A, Geol. Paläont., 12, pp. 243-257.

Senkowiczowa, H. \& Szyperko-Sliwczynska, A., 1975. Stratigraphy and palaeogeography of the Trias. - Geol. Inst. Bull., 252, pp. 131-147.

Schnitzer, W. A., 1969. Zur Paläogeographie des Buntsandsteins im germanischen und alpinen Sedimentationsraum in Bayern. Z. deutsch. geol. Ges., 118, pp. 247-255.

Sindowski, K.-H., 1957. Schüttungsrichtungen und Mineral-Provinzen im westdeutschen Buntsandstein. - Geol. Jb., 73, pp. $277-294$.
Sorgenfrei, Th., 1969. Geological perspectives in the North Sea Area. - Bull. Geol. Soc. Denmark, 19, pp. 160-196.

Sorgenfrei, Th. \& Buch, A., 1964. Deep tests in Denmark 1935-1959. - Danm. geol. Unders., III Rk., 36, 146 pp

Stets, J. \& Wurster, P., 1977. Der Lichtenauer Randstrom des Schilfsandstein-Deltas. - Z. deutsch. geol. Ges., 128, pp. 99-120.

Visscher, H., 1971. The Permian and Triassic of the Kingscourt outlier, Ireland. A palynological investigation related to regional stratigraphical problems in the Permian and Triassic of Western Europe. - Geol. Surv. Ireland, Spec. Paper, 1, 114 pp.

Walker, T. R., 1967. Formation of red beds in modern and ancient deserts. - Geol. Soc. Amer. Bull., 78, pp. 353-368.

Walker, T. R., 1974. Formation of red beds in moist tropical climates: A hypothesis. - Geol. Soc. Amer. Bull., 85, pp. 633-638.

Warrington, G., 1970. The stratigraphy and palaeontology of the 'Keuper' Series of the central Midlands of England. - Q. Jl geol. Soc. Lond., 126, pp. 183-223.

Will, H.-J., 1969. Untersuchungen zur Stratigraphie und Genese des Oberkeupers in Nordwestdeutschlands. - Beih. Geol. Jb., $54,239 \mathrm{pp}$.

Ziegler, P., 1977. Geology and hydrocarbon provinces of the North Sea. - GeoJournal 1, pp. 7-32.

Received after the final typing of

the manuscript:

Gajewska, I., 1978. The stratigraphy and development of the Keuper in north-west Poland. - Prace Inst. Geol., 87, pp. 5-60. (In Polish w/ English résumé).

Marcinkiewicz, T., 1978. Megaspore assemblages in the Keuper of Poland. - Ibidem, pp. 61-84. (In Polish w/ English résumé)

Ziegler, P., 1978. North-western Europe: Tectonics and basin development. - Geol. Mijnb., 57, pp. 589-626. 


\section{Triassic data tables}

\section{General remarks}

T. D. (Total Depth) is the deepest record in the well by either the Driller (Drill,) or the wire line logging company (Log.).

- in front of a thickness value indicates that the top is eroded.

+ following a thickness value means that the unit is not fully penetrated.

All thicknesses are calculated from the log reading values in feet or meter below Kelly Bushing (K.B.) or Rotary Table (R.T.) and with the log scale indicated after the log type used. When wire line logs are not available the lithological well site log inclusive of rate of penetration has been used ("Mud log"). The values given as metres below Mean Sea Level are all abbreviated and are not to be used for thickness calculations.

Abbreviations of wire line $\log$ types used for the boundary definitions: GR = Gamma Ray; $\mathrm{ITT}=$ Interval Transit Time; SP $=$ Spontaneous Potential; Res $=$ Resistivity; $\mathrm{N}=$ Neutron; FDC $=$ Formation Density; $\mathrm{CNL}=$ Compensated Neutron.

\section{Bunter Shale Formation well data}

Well
Arnum 1
Da. Nordsø B-1
Da. Nordsø C-1
Gassum 1
Grindsted 1
Hønning 1
Mors 1
Nøvling 1
Ringe 1
Rødby 1
Rødby 2
Rødekro 1
Rønde 1
Slagelse 1
Tønder 1
Tønder 2
Ørslev 1
Ábenrå 1

\begin{tabular}{|c|c|}
\hline $\begin{array}{l}\text { Depth b. KB } \\
\text { (m or feet) }\end{array}$ & $\begin{array}{l}\text { Log-type } \\
\text { (top/base) }\end{array}$ \\
\hline $5067-5734^{\prime}$ & $\mathrm{GR} / \mathrm{GR}+\operatorname{Res} 1 ; 500$ \\
\hline $9986-10181^{\prime}$ & FDC/FDC $1: 200$ \\
\hline $8115-8419^{\prime}$ & $\mathrm{GR}+\mathrm{FDC} / \mathrm{GR}+\mathrm{FDC} 1: 200$ \\
\hline \multicolumn{2}{|c|}{ Not distinctive - included in Bunter Sandstone Formation } \\
\hline $1493-1602 \mathrm{~m}$ & $\mathrm{GR}+\mathrm{N} / \mathrm{GR}+\mathrm{N} 1: 1000$ \\
\hline $1775-1995 \mathrm{~m}$ & $\mathrm{SP}+\mathrm{Res} / \mathrm{GR}+\mathrm{N} 1: 1000$ \\
\hline \multicolumn{2}{|c|}{ Not distinctive - included in Bunter Sandstone Formation } \\
\hline$? 3240.6-3421.6 \mathrm{~m}$ & ITT/ITT 1:200 \\
\hline $3780-? 4201^{\prime}$ & $\mathrm{SP}+\operatorname{Res} / \mathrm{SP}+\operatorname{Res} 1: 500$ \\
\hline $4551-5035^{\prime}$ & SP+Res/TD (Log.) 1:500 \\
\hline $4412-5453^{\prime}$ & $\mathrm{SP}+\operatorname{Res} / \mathrm{SP}+\operatorname{Res} 1: 500$ \\
\hline $1462-1637 \mathrm{~m}$ & SP+Res/SP+Res $1: 1000$ \\
\hline \multicolumn{2}{|c|}{ Not distinctive - included in Bunter Sandstone Formation } \\
\hline $2057-2257 \mathrm{~m}$ & $G R+N / G R+N 1: 1000$ \\
\hline $5977^{\prime}-7065^{\prime}$ & GR+Res/GR 1:500 \\
\hline $6948^{\prime}-7994^{\prime}$ & Res/Mud $\log 1: 500$ \\
\hline $1204.0-1450.5 \mathrm{~m}$ & $\mathrm{GR}+\mathrm{ITT} / \mathrm{GR}+\mathrm{ITT} 1: 200$ \\
\hline $5365-6084^{\prime}$ & $\mathrm{SP}+\operatorname{Res} / \mathrm{SP}+\mathrm{Res} 1: 500$ \\
\hline
\end{tabular}

Depth b. MSL

m $\mathrm{m}$

1502-1705 203

3008-3068 -59

2436-2529 93

1458-1567 $\quad 109$

1743-1963 220

3171-3352 181

1075-1204 128

1382-1529 $148+$

1337-1654 317

1410-1585 175

2016-2216 200

1808-2140 332

2100-2419 319

1181-1428 247

1579-1798 219 
Well

Depth b. KB
(m or feet)

Arnum 1

Da. Nordsø $\mathrm{C}-1$

*Gassum 1

Grindsted 1

Hønning 1

*Mors 1

Nøvling 1

Ringe 1

Rødby 1

Rødby 2

Rødekro 1

* Rønde 1

Slagelse 1

Tønder 1

Tonder 2

Ørslev 1

Åbenrå 1

\section{Log-type \\ (top/base)}

SP+Res/GR 1:500

$\mathrm{GR}+\mathrm{FDC} / \mathrm{GR}+\mathrm{FDC}$ 1:200

Res/Mud $\log 1: 500$

$\mathrm{GR}+\mathrm{N} / \mathrm{GR}+\mathrm{N} 1: 1000$

$\mathrm{SP}+\operatorname{Res} / \mathrm{SP}+\operatorname{Res} 1: 1000$

GR+ITT/TD (Drill.) 1:200

ITT/ITT 1:200

SP+Res/SP+Res 1:500

$\mathrm{SP}+\mathrm{Res} / \mathrm{SP}+\operatorname{Res} 1: 500$

SP+Res/SP+Res 1:500

$\mathrm{SP}+\mathrm{Res} / \mathrm{SP}+\mathrm{Res} 1: 1000$

$\mathrm{GR}+\mathrm{N} / \mathrm{ITT} 1: 200$

$\mathrm{GR}+\mathrm{N} / \mathrm{GR}+\mathrm{N} 1: 1000$

$\mathrm{GR}+\operatorname{Res} / \mathrm{GR}+\operatorname{Res} 1: 500$

Res/Res 1:500

$\mathrm{GR}+\mathrm{ITT} / \mathrm{GR}+\mathrm{ITT} 1: 200$

$\mathrm{SP}+\mathrm{Res} / \mathrm{SP}+\operatorname{Res} 1: 500$
Depth b. MSL Thickness $\mathrm{m}$ m

1377-1502 125

1955-2436 482

2689-3383 694

1401-1458 57

1560-1743 183

4367-5303 936+

3126-3171 45

1063-1075 12

1125-1382 256

1096-1337 240

1331-1410 79

4013-4591 578

1824-2016 192

1606-1808 203

1924-2100 $\quad 176$

1064-1181 117

1467-1579 112

* May also be included in the Skagerrak Formation

\section{Ørslev Formation well data}

\section{Table 3}

Well
Arnum 1
Da. Nordsø C-1
Da. Nordsø R-1
*Gassum 1
Grindsted 1
Hønning 1
*Mors 1
Nøvling 1
Ringe 1
Rødby 1
Rødby 2
Rødekro 1
*Rønde 1
Slagelse 1
Tønder 1
Tønder 2
Ørslev 1
Åbenră 1

$\begin{aligned} & \text { Depth b. KB } \\ & \text { (m or fect) }\end{aligned}$
$4263-4658^{\prime}$
$6158-6536^{\prime}$
If present included
$7980-9013^{\prime}$
$1311-1436 \mathrm{~m}$
$1453-1592 \mathrm{~m}$
$3932.8-4384.5 \mathrm{~m}$
$3112.4-3195.3 \mathrm{~m}$
$3404-3740^{\prime}$
$3185-3710^{\prime}$
$3120-3623^{\prime}$
$1316-1383 \mathrm{~m}$
$3820.0-4055.0 \mathrm{~m}$
$1763-1865 \mathrm{~m}$
$4713-5312^{\prime}$
$5790-6370^{\prime}$
$980.6-1087.0 \mathrm{~m}$
$4566-4998$

Log-type

(top/base)

$\mathrm{SP}+\mathrm{Res} / \mathrm{SP}+\mathrm{Res} 1: 500$

$\mathrm{GR}+\mathrm{FDC} / \mathrm{GR}+\mathrm{FDC} 1: 200$

Depth b. MSL

$\mathrm{m}$

1257-1377

1840-1955

2374-2689

Res/GR 1:500

$\mathrm{GR}+\mathrm{N} / \mathrm{GR}+\mathrm{N} 1: 1000$

SP+Res/SP+Res 1:1000

GR+ITT/GR+ITT $1: 200$

ITT/ITT 1:200

$\mathrm{SP}+\operatorname{Res} / \mathrm{SP}+\operatorname{Res} 1: 500$

$\mathrm{SP}+\operatorname{Res} / \mathrm{SP}+\mathrm{Res} 1: 500$

$\mathrm{SP}+\operatorname{Res} / \mathrm{SP}+$ Res 1:500

$\mathrm{SP}+\operatorname{Res} / \mathrm{SP}+\operatorname{Res} 1: 1000$

$\mathrm{GR}+\mathrm{N} / \mathrm{GR}+\mathrm{N} 1: 200$

$\mathrm{GR}+\mathrm{N} / \mathrm{GR}+\mathrm{N} 1: 1000$

$\mathrm{SP}+\operatorname{Res} / \mathrm{GR}+\operatorname{Res} 1: 500$

SP+Res/Res 1:500

GR+ITT/GR+ITT 1:200

SP+Res/SP+Res 1:500
$1276-1401 \quad 125$

$1421-1560 \quad 139$

$3915-4367 \quad 452$

3043-3126 83

961-1063 102

965-1125 $\quad 160$

943-1096 153

1264-1331 67

3778-4013 235

1722-1824 102

1423-1606 183

1747-1924 177

958-1064 106

1336-1467 132

\section{Ørslev Formation or ?older Triassic}

Glamsbjerg 1

2910-2973'

SP+Res/SP+Res 1:500

$816-835$

19

* Transitional to the Skagerrak Formation 
Falster Formation well data

Table 4

\begin{tabular}{|c|c|c|c|c|}
\hline Well & $\begin{array}{l}\text { Depth b. KB } \\
\text { (m or feet) }\end{array}$ & $\begin{array}{l}\text { Log-type } \\
\text { (top/base) }\end{array}$ & $\begin{array}{l}\text { Depth b. MSL } \\
\mathrm{m}\end{array}$ & $\begin{array}{l}\text { Thickness } \\
\mathrm{m}\end{array}$ \\
\hline Arnum 1 & $3758-4263^{\prime}$ & $\mathrm{SP}+\mathrm{Re} / \mathrm{SP}+\mathrm{Res} 1: 500$ & $1103-1257$ & 154 \\
\hline Da. Nordsø A-2 & \multicolumn{4}{|c|}{ See Dowsing Dolomitic Formation } \\
\hline Da. Nords $\mathrm{C}-1$ & $5848-6158^{\prime}$ & $\mathrm{GR}+\mathrm{FDC} / \mathrm{GR}+\mathrm{FDC} 1: 200$ & $1745-1840$ & 95 \\
\hline Da. Nordsø R-1 & $4873-5810^{\prime}$ & $\mathrm{FDC}+\mathrm{CNL} / \mathrm{FDC}+\mathrm{CNL} 1: 200$ & $1459-1745$ & 286 \\
\hline${ }^{*}$ Gassum 1 & $7613-7980^{\prime}$ & $\mathrm{SP}+\operatorname{Res} / \mathrm{SP}+\operatorname{Res} 1: 500$ & $2263-2374$ & 112 \\
\hline Glamsbjerg 1 & $2824-2910^{\prime}$ & $\mathrm{SP}+\operatorname{Res} / \mathrm{SP}+\operatorname{Res} 1: 500$ & $789-816$ & -26 \\
\hline Grindsted 1 & $1211-1311 \mathrm{~m}$ & $\mathrm{GR}+\mathrm{N} / \mathrm{GR}+\mathrm{N} 1: 1000$ & $1176-1276$ & 100 \\
\hline Hønning 1 & $1293-1453 \mathrm{~m}$ & $\mathrm{SP}+\operatorname{Res} / \mathrm{SP}+\operatorname{Res} 1: 1000$ & $1261-1421$ & 160 \\
\hline *Mors 1 & $3736.7-3932.8 \mathrm{~m}$ & $\mathrm{GR}+\mathrm{ITT} / \mathrm{GR}+\mathrm{ITT} 1: 200$ & $3719-3915$ & 196 \\
\hline Nøvling 1 & $3038.0-3112.4 \mathrm{~m}$ & ITT/ITT $1: 200$ & $2969-3043$ & 74 \\
\hline Ringe 1 & $? 3077-3404^{\prime}$ & $\mathrm{SP}+\operatorname{Res} / \mathrm{SP}+\operatorname{Res} 1: 500$ & $861-961$ & 100 \\
\hline Rødby 1 & $2584-3185^{\prime}$ & $\mathrm{SP}+\operatorname{Res} / \mathrm{SP}+\mathrm{Res} 1: 500$ & $782-965$ & 183 \\
\hline Rodby 2 & $2535-3120^{\prime}$ & $\mathrm{SP}+\operatorname{Res} / \mathrm{SP}+\operatorname{Res} 1: 500$ & $765-943$ & 178 \\
\hline Rødekro 1 & $1191-1316 \mathrm{~m}$ & $\mathrm{SP}+\operatorname{Res} / \mathrm{SP}+\operatorname{Res} 1: 1000$ & $1139-1264$ & 125 \\
\hline${ }^{*}$ Rønde 1 & $3698.3-3820.0 \mathrm{~m}$ & $\mathrm{GR}+\mathrm{N} / \mathrm{GR}+\mathrm{N} 1: 200$ & $3656-3778$ & 121 \\
\hline Slagelse 1 & $1631-1763 \mathrm{~m}$ & $\mathrm{GR}+\mathrm{N} / \mathrm{GR}+\mathrm{N} 1: 1000$ & $1590-1722$ & 132 \\
\hline Tønder 1 & $4160-4713^{\prime}$ & $\mathrm{SP}+\operatorname{Res} / \mathrm{SP}+\operatorname{Res} 1: 500$ & $1255-1423$ & 169 \\
\hline Tønder 2 & $5244-5790^{\prime}$ & $\mathrm{SP}+\operatorname{Res} / \mathrm{SP}+\operatorname{Res} 1: 500$ & $1581-1747$ & 166 \\
\hline Vinding 1 & $? 7109-7985^{\prime}$ & Mud log/TD (Drill.) & $? 2105-2372$ & $? 267+$ \\
\hline Ørslev 1 & $841.0-980.6 \mathrm{~m}$ & GR+ITT/GR+ITT $1: 200$ & $818-958$ & 140 \\
\hline Åbenrå 1 & $4053-4566^{\prime}$ & $\mathrm{SP}+\operatorname{Res} / \mathrm{SP}+\operatorname{Res} 1: 500$ & $1179-1336$ & 156 \\
\hline
\end{tabular}

* Transitional to the Skagerrak Formation

\section{Tønder Formation well data}

\section{Table 5}

$\begin{array}{lllcr}\text { Well } & \begin{array}{l}\text { Depth b. KB } \\ \text { (m or feet) }\end{array} & \begin{array}{l}\text { Log-type } \\ \text { (top/base) }\end{array} & \begin{array}{l}\text { Depth b. MSL } \\ \mathrm{m}\end{array} & \begin{array}{l}\text { Thickness } \\ \mathrm{m}\end{array} \\ \text { Arnum 1 } & 3266-3758^{\prime} & \text { SP+Res/SP+Res 1:500 } & 953-1103 & 150 \\ \text { Da. Nordsø C-1 } & 5204-5848^{\prime} & \text { GR+FDC/GR+FDC 1:200 } & 1549-1745 & 196 \\ \text { Da. Nordsø R-1 } & 4360-4873^{\prime} & \text { FDC+CNL/FDC+CNL 1:200 } & 1303-1459 & -156 \\ \text { Gassum 1 } & 6823-7613^{\prime} & \text { Res/SP+Res 1:500 } & 2022-2263 & 241 \\ \text { Grindsted 1 } & 1042-1211 \mathrm{~m} & \text { GR+N/GR+N 1:1000 } & 1007-1176 & 169 \\ \text { Hønning 1 } & 1124-1293 \mathrm{~m} & \text { SP+Res/SP+Res 1:1000 } & 1092-1261 & 169 \\ \text { Mors 1 } & 3498.3-3736.7 \mathrm{~m} & \text { GR+ITT/GR+ITT 1:200 } & 3480-3719 & 238 \\ \text { Nøvling 1 } & 2729.7-3038.0 \mathrm{~m} & \text { ITT/ITT 1:200 } & 2661-2969 & 308 \\ \text { Rødekro 1 } & 1077-1191 \mathrm{~m} & \text { SP+Res/SP+Res 1:1000 } & 1025-1139 & 114 \\ \text { Rønde 1 } & 3457.0-3698.3 \mathrm{~m} & \text { GR+N/GR+N 1:200 } & 3415-3656 & 241 \\ \text { Tønder 1 } & 3490-4160^{\prime} & \text { SP+Res/SP+Res 1:500 } & 1050-1255 & 204 \\ \text { Tønder 2 } & 4408-5244^{\prime} & \text { SP+Res/SP+Res 1:500 } & 1326-1581 & 255 \\ \text { Vinding 1 } & 6505-? 7109^{\prime} & \text { Mud log + drill. rate } & 1921-? 2105 & ? 184 \\ \text { Abenrå 1 } & 3600-4053^{\prime} & \text { SP+Res/SP+Res 1:500 } & 1041-1179 & 138\end{array}$


Oddesund Formation well data

Well

Da. Nordsø C-1

Da. Nordsø O-1

Gassum 1

Grindsted 1

Harte 2

Hobro 1

Horsens 1

Hønning 1

Mors 1

Nøvling 1

*Ringe 1

*Rødby 1

*Rødby 2

Rødekro 1

Ronde 1

*?Slagelse 1

Thisted 1

Tonder 1

Tønder 2

Ullerslev 1

Vemb 1

Vinding 1

Voldum 1

* Ørslev 1

Ábenrå 1

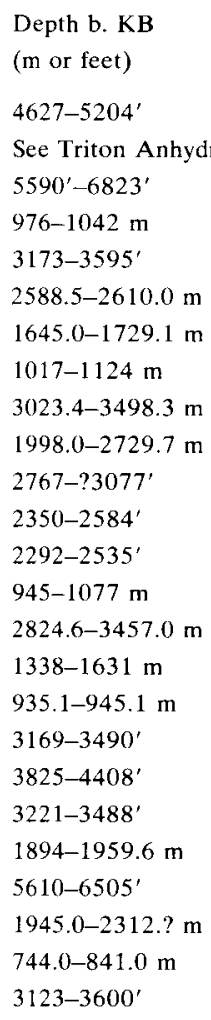

* Atypically developed ("Ringe Beds")

\section{Log-type}

(top/base)

$\mathrm{GR}+\mathrm{FDC} / \mathrm{GR}+\mathrm{FDC} 1: 200$

mation etc

GR/Res 1:500

$\mathrm{GR}+\mathrm{N} / \mathrm{GR}+\mathrm{N} 1: 1000$

Mud $\log$ /Mud log

GR+ITT/TD (Drill.) 1:200

SP+Res/TD (Drill.) 1:1000

SP+Res/SP+Res 1:1000

GR+ITT/GR+ITT 1:200

ITT/ITT 1:200

$\mathrm{SP}+\operatorname{Res} / \mathrm{SP}+\operatorname{Res} 1: 500$

$\mathrm{SP}+\operatorname{Res} / \mathrm{SP}+\operatorname{Res} 1: 500$

$\mathrm{SP}+\operatorname{Res} / \mathrm{SP}+\operatorname{Res} 1: 500$

$\mathrm{SP}+\operatorname{Res} / \mathrm{SP}+\operatorname{Res} 1: 1000$

$\mathrm{GR}+\mathrm{N} / \mathrm{GR}+\mathrm{N} 1: 200$

$\mathrm{GR}+\mathrm{N} / \mathrm{GR}+\mathrm{N} 1: 1000$

$\mathrm{GR}+\mathrm{ITT} / \mathrm{TD}$ (Drill.)

$\mathrm{SP}+\operatorname{Res} / \mathrm{SP}+\operatorname{Res} 1: 500$

$\mathrm{SP}+\operatorname{Res} / \mathrm{SP}+\operatorname{Res} 1: 500$

$\mathrm{SP}+\operatorname{Res} / \mathrm{TD}$ (Drill.)

SP+Res/TD (Log.) 1:1000

Mud $\log +$ drill. rate

Gr+ITT/TD (Drill.) 1:200

$\mathrm{GR}+\mathrm{ITT} / \mathrm{GR}+\mathrm{ITT}$ 1:200

$\mathrm{SP}+\operatorname{Res} / \mathrm{SP}+\operatorname{Res} 1: 500$

$\begin{array}{lc}\text { Depth b. MSL } & \text { Thickness } \\ \mathrm{m} & \mathrm{m} \\ 1373-1549 & -176 \\ & \\ 1646-2022 & 376 \\ 941-1007 & -66 \\ 936-1065 & 129+ \\ 2556-2578 & 22+ \\ 1588-1672 & 84+ \\ 985-1092 & -107 \\ 3005-3480 & 475 \\ 1929-2661 & 732 \\ 767-861 & -95 \\ 711-782 & 71 \\ 691-765 & 74 \\ 893-1025 & -132 \\ 2782-3415 & 632 \\ 1297-1590 & 293 \\ 899-909 & 10+ \\ 953-1050 & -98 \\ 1149-1326 & 178 \\ 957-1038 & 81+ \\ 1878-1944 & 66+ \\ 1648-1921 & 273 \\ 1910-2277 & 367+ \\ 721-818 & -97 \\ 896-1041 & 145\end{array}$

\section{Vinding Formation well data}

Table 7

$\begin{array}{ll}\text { Well } & \begin{array}{l}\text { Depth b. KB } \\ \text { (m or feet) }\end{array} \\ \text { Da. Nordsø K-1 } & 6735-6869^{\prime} \\ \text { Gassum 1 } & 5406-5590^{\prime} \\ \text { Harte 2 } & 3103-3173^{\prime} \\ \text { Hobro 1 } & 2521.3-2588.5 \mathrm{~m} \\ \text { Horsens 1 } & 1600-1645 \mathrm{~m} \\ \text { Mors 1 } & 2934.6-3023.4 \mathrm{~m} \\ \text { Novling 1 } & 1932.0-1998.0 \mathrm{~m} \\ \text { *Rodby 1 } & 2260-2350^{\prime} \\ \text { *Rodby 2 } & 2208-2292^{\prime} \\ \text { Ronde 1 } & 2753.0-2824.6 \mathrm{~m} \\ \text { Slagelse 1 } & 1287-1338 \mathrm{~m} \\ \text { Thisted 1 } & 871.0-935.1 \mathrm{~m} \\ \text { *Tonder 2 } & 3675-3825^{\prime} \\ \text { Ullerslev 1 } & 3088-3221^{\prime} \\ \text { Vemb 1 } & 1853-1894 \mathrm{~m} \\ \text { Vinding 1 } & 5420-5610^{\prime} \\ \text { Voldum 1 } & 1885.0-1945.0 \mathrm{~m} \\ \text { * Åbenrå 1 } & 3108-3123^{\prime}\end{array}$

\author{
Log-type \\ (top/base) \\ $\mathrm{SP}+\mathrm{Res} / \mathrm{SP}+\operatorname{Res} 1: 200$ \\ $\mathrm{GR}+$ Core description 1:500 \\ Mud $\log /$ Mud log \\ GR+ITT/GR+ITT 1:200 \\ $\mathrm{SP}+\mathrm{Res} / \mathrm{SP}+\mathrm{Res} 1: 1000$ \\ GR+ITT/GR+ITT 1:200 \\ ITT/ITT 1:200 \\ $\mathrm{SP}+\operatorname{Res} / \mathrm{SP}+\operatorname{Res} 1: 500$ \\ $\mathrm{SP}+\operatorname{Res} / \mathrm{SP}+\operatorname{Res} 1: 500$ \\ $\mathrm{GR}+\mathrm{N} / \mathrm{GR}+\mathrm{N} 1: 200$ \\ $\mathrm{GR}+\mathrm{N} / \mathrm{GR}+\mathrm{N} 1: 1000$ \\ $\mathrm{GR}+\mathrm{ITT} / \mathrm{GR}+\mathrm{ITT} 1: 200$ \\ $\mathrm{SP}+\operatorname{Res} / \mathrm{SP}+\operatorname{Res} 1: 500$ \\ $\mathrm{SP}+\operatorname{Res} / \mathrm{SP}+\operatorname{Res} 1: 500$ \\ $\mathrm{SP}+\operatorname{Res} / \mathrm{SP}+\operatorname{Res} 1: 1000$ \\ Mud $\log +$ drill. rate \\ GR+ITT/GR+ITT 1:200 \\ $\mathrm{SP}+\operatorname{Res} / \mathrm{SP}+\operatorname{Res} 1: 500$
}

\begin{tabular}{|c|c|}
\hline $\begin{array}{l}\text { Depth b. MSL } \\
\text { m }\end{array}$ & $\begin{array}{l}\text { Thickness } \\
\text { m }\end{array}$ \\
\hline $2016-2057$ & 41 \\
\hline $1590-1646$ & 56 \\
\hline $915-936$ & -21 \\
\hline $2489-2556$ & 67 \\
\hline $1543-1588$ & 45 \\
\hline 2917-3005 & 89 \\
\hline $1863-1929$ & 66 \\
\hline $683-711$ & 27 \\
\hline $665-691$ & 26 \\
\hline $2711-2782$ & 72 \\
\hline $1246-1297$ & 51 \\
\hline $835-899$ & 64 \\
\hline $1103-1149$ & 46 \\
\hline $916-957$ & 41 \\
\hline $1837-1878$ & 41 \\
\hline $1591-1648$ & 58 \\
\hline $1850-1910$ & 60 \\
\hline $891-896$ & -5 \\
\hline
\end{tabular}

* Wells situated on the southern flank of the Ringkøning-Fyn High 
Well

Børglum 1

Da. Nordsø $\mathrm{F}-1$

Da. Nordsø J-1

Da. Nurdse K-1

Fjerritslev 2

Flyvbjerg 1

Frederikshavn 1

Frederikshavn 2

Fredrikshavn 3

Gassum 1

Hobro 1

Horsens 1

Lavø 1

Mors 1

Nøvling 1

*Rødby 1

*Rødby 2

Rønde 1

Skagen 2

Slagelse 1

Thisted 1

*Tønder 2

Ullerslev 1

Vedsted 1

Vemb 1

Vinding 1

Voldum 1

* Ørslev 1

\section{Log-type}

(top/base)

SP+Res/TD (Log.) 1:500

GR + ITT/GR+ITT 1:200

$\mathrm{GR}+\mathrm{ITT} / \mathrm{GR}+\mathrm{ITT} 1: 200$

SP+Res/SP+Res 1:200

Mud $\log /$ Mud $\log$

$\mathrm{SP}+\operatorname{Res} / \mathrm{SP}+\operatorname{Res} 1: 1000$

$\mathrm{SP}+\operatorname{Res} / \mathrm{SP}+\operatorname{Res} 1: 500$

$\mathrm{SP}+\operatorname{Res} / \mathrm{SP}+\operatorname{Res} 1: 500$

$\mathrm{SP}+\operatorname{Res} / \mathrm{SP}+\operatorname{Res} 1: 500$

$\mathrm{GR}+\mathrm{Mud} \log /$

$\mathrm{GR}+\mathrm{Mud} \log 1: 500$

$\mathrm{GR}+\mathrm{ITT} / \mathrm{GR}+\mathrm{ITT} 1: 200$

$\mathrm{SP}+\operatorname{Res} / \mathrm{SP}+\operatorname{Res} 1: 1000$

$\mathrm{SP}+\operatorname{Res} / \mathrm{SP}+\operatorname{Res} 1: 1000$

$\mathrm{GR}+\mathrm{ITT} / \mathrm{GR}+\mathrm{ITT} 1: 200$

ITT/ITT $1: 200$

$\mathrm{SP}+\operatorname{Res} / \mathrm{SP}+\operatorname{Res} 1: 500$

$\mathrm{SP}+\mathrm{Res} / \mathrm{SP}+\mathrm{Res} 1: 500$

$\mathrm{GR}+\mathrm{N} / \mathrm{GR}+\mathrm{N} 1: 200$

Core description

$\mathrm{GR}+\mathrm{N} / \mathrm{GR}+\mathrm{N} 1: 1000$

$\mathrm{GR}+\mathrm{ITT} / \mathrm{GR}+\mathrm{ITT} 1: 200$

$\mathrm{SP}+\mathrm{Res} / \mathrm{SP}+\mathrm{Res}$ 1:500

$\mathrm{SP}+\operatorname{Res} / \mathrm{SP}+$ Res $1: 500$

$\mathrm{SP}+\operatorname{Res} / \mathrm{SP}+\operatorname{Res} 1: 1000$

$\mathrm{SP}+\operatorname{Res} / \mathrm{SP}+\operatorname{Res} 1: 1000$

Mud log + drill. rate

$\mathrm{GR}+\mathrm{ITT} / \mathrm{GR}+\mathrm{ITT}$ 1:200

$\mathrm{GR}+\mathrm{ITT} / \mathrm{GR}+\mathrm{ITT} 1: 200$
Depth b. MSL Thickness

m

$\mathrm{m}$

1349-1504 155

2041-2117 76

1697-1769 72

1948-2016 67

2225-2321 ?96

1261-1457 196

893-971 77

869-948 78

$860-924 \quad 64$

$1460-1590 \quad 130$

2343-2489 $\quad 146$

1449-1543 94

2105-2340 235

2750-2917 $\quad 166$

1778-1863 85

467-683 217

445-665 220

2571-2711 139

552-563 11

1109-1246 $\quad 137$

$710-835 \quad 125$

1070-1103 - 33

$817-916 \quad 99$

$1892-2032 \quad 140$

1779-1837 58

$1539-1591 \quad 51$

$1722-1850 \quad 129$

$500-721 \quad 221$

* Wells situated on the southern flank of the Ringkøbing-Fyn High.

Dowsing Dolomitic Formation well data

Well

$\begin{aligned} & \text { Depth b. KB } \\ & \text { (m or feet) } \\ & 10050-11143^{\prime}\end{aligned}$

Log-type

(top/base)

*Da. Nordsø A-2
Mud $\log / T D$ (Drill.)

\section{Table 9}

$\begin{array}{ll}\text { Depth b. MSL. } & \text { Thickness } \\ \mathrm{m} & \mathrm{m} \\ 3027-3360 & 333+\end{array}$

\section{Dudgeon Saliferous Formation well data}

$\begin{array}{lllll}\text { Well } & \begin{array}{l}\text { Depth b. KB } \\ \text { (m or feet) }\end{array} & \begin{array}{l}\text { Log-type } \\ \text { (top/base) }\end{array} & \text { Depth b. MSL } & \begin{array}{l}\text { Thickness } \\ \mathrm{m}\end{array} \\ \text { Da. Nordsø O-1 } & 11193-11740^{\prime} & \text { GR+1TT/TD (Drill.) 1:200) } & 3384-3550 & 167+\end{array}$

\section{Triton Anhydritic Formation well data}

$\begin{array}{lllll}\text { Well } & \begin{array}{l}\text { Depth b, KB } \\ \text { (m or feet) }\end{array} & \begin{array}{l}\text { Log-type } \\ \text { (top/base) }\end{array} & \text { Depth b. MSL } & \text { Thickness } \\ \text { Da. Nordsø O-1 } & 10400-11193^{\circ} & \text { GR+ITT/GR+ITT 1:200 } & 3142-3384 & 242\end{array}$




\section{?Winterton Formation well data}

Well

Da. Nordsø O-1

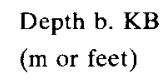

10287-10400'

\section{Log-type}

(top/base)

GR+ITT/GR+ITT 1:200
Depth b. MSL Thickness

$\mathrm{m}$

m

3107-3142 34

* Upper part of section most probably includes lower part of the Dudgeon Saliferous Formation. Top Muschelkalk Halite Member at 10792'

Smith Bank Formation well data

$\begin{array}{ll}\text { Well } & \begin{array}{l}\text { Depth b. KB } \\ \text { (m or feet) }\end{array} \\ & \end{array}$

Skagerrak Formation well data

$\begin{array}{ll}\text { Well } & \begin{array}{l}\text { Depth b. KB } \\ \text { (m or feet) }\end{array} \\ & \begin{array}{l}5184-5482^{\prime} \\ \text { Da. Nordsø D-1 }\end{array} \\ \text { Da. Nordsø F-1 } & 7068-7945^{\prime} \\ \text { Da. Nordsø J-1 } & 5925-6526^{\prime} \\ \text { Da. Nordsø K-1 } & 6869-7525^{\prime} \\ \text { Flyvbjerg 1 } & 1504-1699 \mathrm{~m} \\ \text { Frederikshavn 1 } & 3227-4230^{\prime} \\ \text { Frederikshavn 2 } & 3160-3542^{\prime} \\ \text { Frederikshavn 3 } & 3065-3307^{\prime} \\ \text { Lavø 1 } & 2368-2442 \mathrm{~m} \\ \text { Skagen 2 } & * 1854-2036^{\prime} \\ \text { Vedsted 1 } & 2037.5-2072.9 \mathrm{~m} \\ \text { * below ground elev. } & \end{array}$

Log-type

(top/base)

GR+ITT/GR+ITT 1:200

GR+ITT/TD (Log.) 1:200

GR+ITT/TD (Log.) 1:200

SP+Res/TD (Log.) 1:200

SP+Res/TD (Log.) 1:1000

SP+Res/SP+Res 1:500

SP+Res/TD (Drill.) 1:500

$\mathrm{SP}+\mathrm{Res} / \mathrm{TD}$ (Drill.) 1:500

SP+Res/TD (Log.) 1:1000

Core descript./TD (Drill.)

SP+Res/TD (Log.) 1:1000
Table 10

Depth b. MSL Thickness
m

1634-1687 53

\section{? Skagerrak Formation}

$\begin{array}{lllll}\text { Well } & \begin{array}{l}\text { Depth b. KB } \\ \text { (m or feet) }\end{array} & \begin{array}{l}\text { Log-type } \\ \text { (top/base) }\end{array} & \text { Depth b. MSL } & \begin{array}{l}\text { Thickness } \\ \mathrm{m}\end{array} \\ \text { Fjerritslev 2 } & ? 2329-2344.5 \mathrm{~m} & \text { Mud } \log / \text { TD (Drill.) } & 2321-2337 & 16+\end{array}$


Well

Arnum 1

Da. Nordsø A-2

Da. Nordsø B-1

Da. Nordse $C-1$

Da. Nordsø D-1

*Da. Nordsø F-1

*Da. Nordsø J-1

*Da. Nordsø K-1

Da. Nordsø O-1

Da. Nordsø R-1

*Fjerritslev 2

Flyvbjerg 1

Frederikshavn 1

Frederikshavn 2

Frederikshavn 3

*Gassum 1

Glamsbjerg 1

Grindsted 1

Harte 2

*Hobro 1

*Horsens 1

Hønning 1

Lavg 1

*Mors 1

*Nøvling 1

Ringe 1

Rødby 1

Rødby 2

Rødekro 1

*Rønde 1

Skagen 2

* Slagelse 1

*Thisted 1

Tonder 1

* Tønder 2

*Ullerslev 1

Vedsted 1

*Vemb 1

*Vinding 1

*Voldum 1

Ørslev 1

Åbenrå 1
Depth b. KB
(m or feet)

3266-5734'

10050-11143'

9986-10181'

4627-8419'

5184-5656

6818-7945'

5688.5-6526'

6514-7525'

$10287-11740^{\prime}$

4360-5810'

?2233-2344.5 m

1451-1699 m

3227-4230'

3160-3542'

3065-3307'

$4980-11290^{\prime}$

2824-2973'

976-1602 m

3103-3595'

2375.8-2610.0 m

1506-1729.1 m

1017-1995 m

2293-2442 m

2768.4-5320.9 m

$1847.0-3421.6 \mathrm{~m}$

2767-?4201'

1858-5035'

1767-5453'

945-1637 m

$2613.6-4633.0 \mathrm{~m}$

1854-2036'

$1150-2257 \mathrm{~m}$

$746.0-945.1 \mathrm{~m}$

3169-7065'

3566-7994'

2763-3488'

1943-2072.9 m

$1795-1959.6 \mathrm{~m}$

5252-7985'

$1756.5-2312 . ? \mathrm{~m}$

$614.6-1450.5 \mathrm{~m}$

$3108-6084^{\prime}$
Log-type

(top/base)

$\mathrm{SP}+$ Res/GR+Res 1:500

Mud $\log / T D$ (Drill.)

FDC/FDC 1:200

$\mathrm{GR}+\mathrm{FDC} / \mathrm{GR}+\mathrm{FDC} 1: 200$

$\mathrm{GR}+\mathrm{ITT} / \mathrm{GR}+\mathrm{ITT} 1: 200$

GR+ITT/TD (Log.) 1:200

GR+ITT/TD (Log.) 1:200

SP+Res/TD (Log.) 1:200

GR+ITT/TD (Drill.) 1:200

$\mathrm{FDC}+\mathrm{CNL} / \mathrm{FDC}+\mathrm{CNL} 1: 200$

Mud log/TD (Drill.)

SP+Res/TD (Log.) 1:1000

SP+Res/SP+Res. 1:500

$\mathrm{SP}+\mathrm{Re} / \mathrm{TD}$ (Drill.) 1:500

$\mathrm{SP}+$ Res/TD (Drill.) 1:500

GR+Mud $\log /$ Mud $\log$ 1:500

$\mathrm{SP}+\operatorname{Res} / \mathrm{SP}+\operatorname{Res} 1: 500$

$\mathrm{GR}+\mathrm{N} / \mathrm{GR}+\mathrm{N} 1: 1000$

Mud $\log$ /Mud $\log$

GR+ITT/TD (Drill.) 1:200

SP+Res/TD (Drill.) 1:1000

$\mathrm{SP}+\mathrm{Res} / \mathrm{GR}+\mathrm{N} 1: 1000$

SP+Res/TD (Log.) 1:1000

GR+ITT/TD (Drill.) 1:200

ITT/ITT 1:200

$\mathrm{SP}+\operatorname{Res} / \mathrm{SP}+\operatorname{Res} 1: 500$

SP+Res/TD (Log.) 1:500

$\mathrm{SP}+\operatorname{Res} / \mathrm{SP}+\operatorname{Res} 1: 500$

$\mathrm{SP}+\mathrm{Res} / \mathrm{SP}+\operatorname{Res} 1: 1000$

$\mathrm{GR}+\mathrm{N} / \mathrm{ITT} 1: 200$

Core descript./TD (Drill.)

$\mathrm{GR}+\mathrm{N} / \mathrm{GR}+\mathrm{N} 1: 1000$

GR+ITT/TD (Drill.) 1:200

$\mathrm{SP}+\operatorname{Res} / \mathrm{GR}$ 1:500

$\mathrm{SP}+$ Res/Mud log 1:500

SP+Res/TD (Drill.) 1:500

SP+Res/TD (Log.) 1:1000

$\mathrm{SP}+$ Res/TD (Log.) 1:1000

Mud log + drill. rate/TD (Drill.)1539-2372

GR + ITT/TD (Drill.) 1:200 1722-2277

$\mathrm{GR}+\mathrm{ITT} / \mathrm{GR}+\mathrm{ITT} 1: 200 \quad 592-1428$

$\mathrm{SP}+\operatorname{Res} / \mathrm{SP}+\operatorname{Res} 1: 500$
Depth b. MSL

$\mathrm{m}$

Thickness

$-333+$

$3008-3068-59$

$-1156$

$-144$

$344+$

$255+$

1948-2257 308+

$3107-3550 \quad 443+$

$-442$

$248+$

948-1064 -116+

$924-998-74+$

1923

$-45$

$-626$

$-150+$

$234+$

$223+$

$-978$

$149+$

$2553+$

1575

$-437$

$968+$

1123

$-692$

2019

$55+$

1107

$199+$

$-1188$

$-1350$

$221+$

$130+$

$165+$

$833+$

$556+$

836

$-907$

* Top Triassic $=$ top Gassum Formation

Top Triassic is supposed not to have been reached in Børglum 1. 


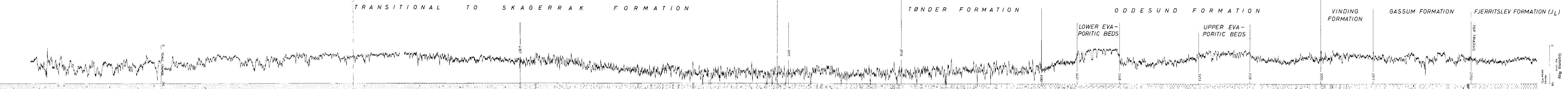

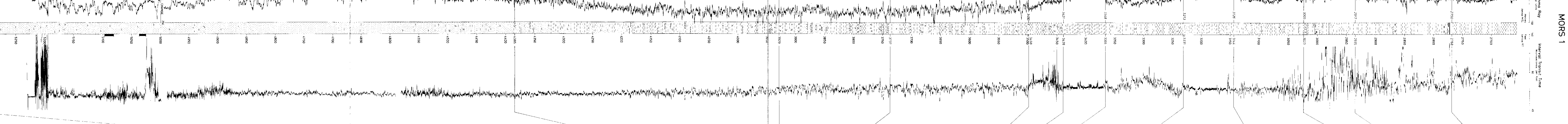

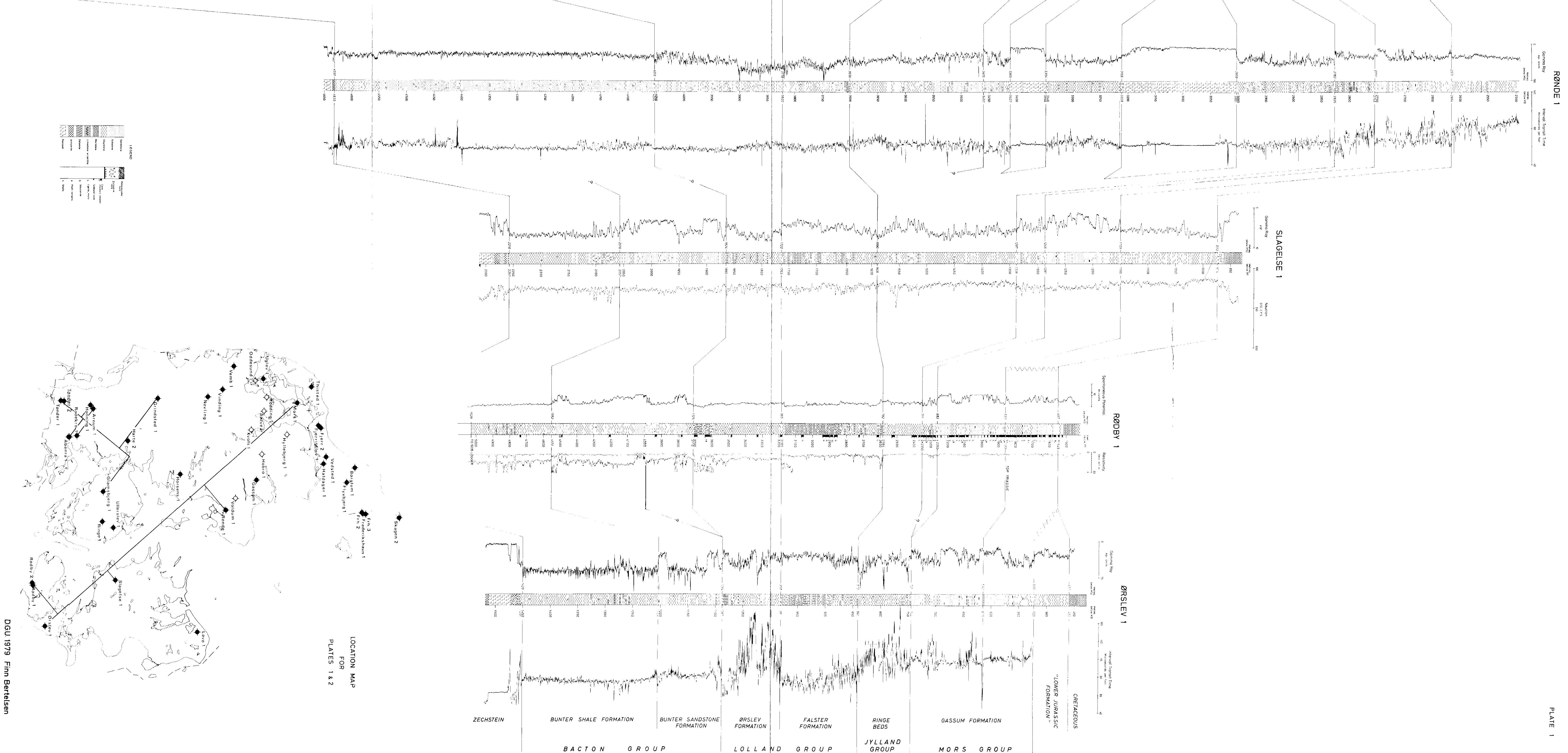




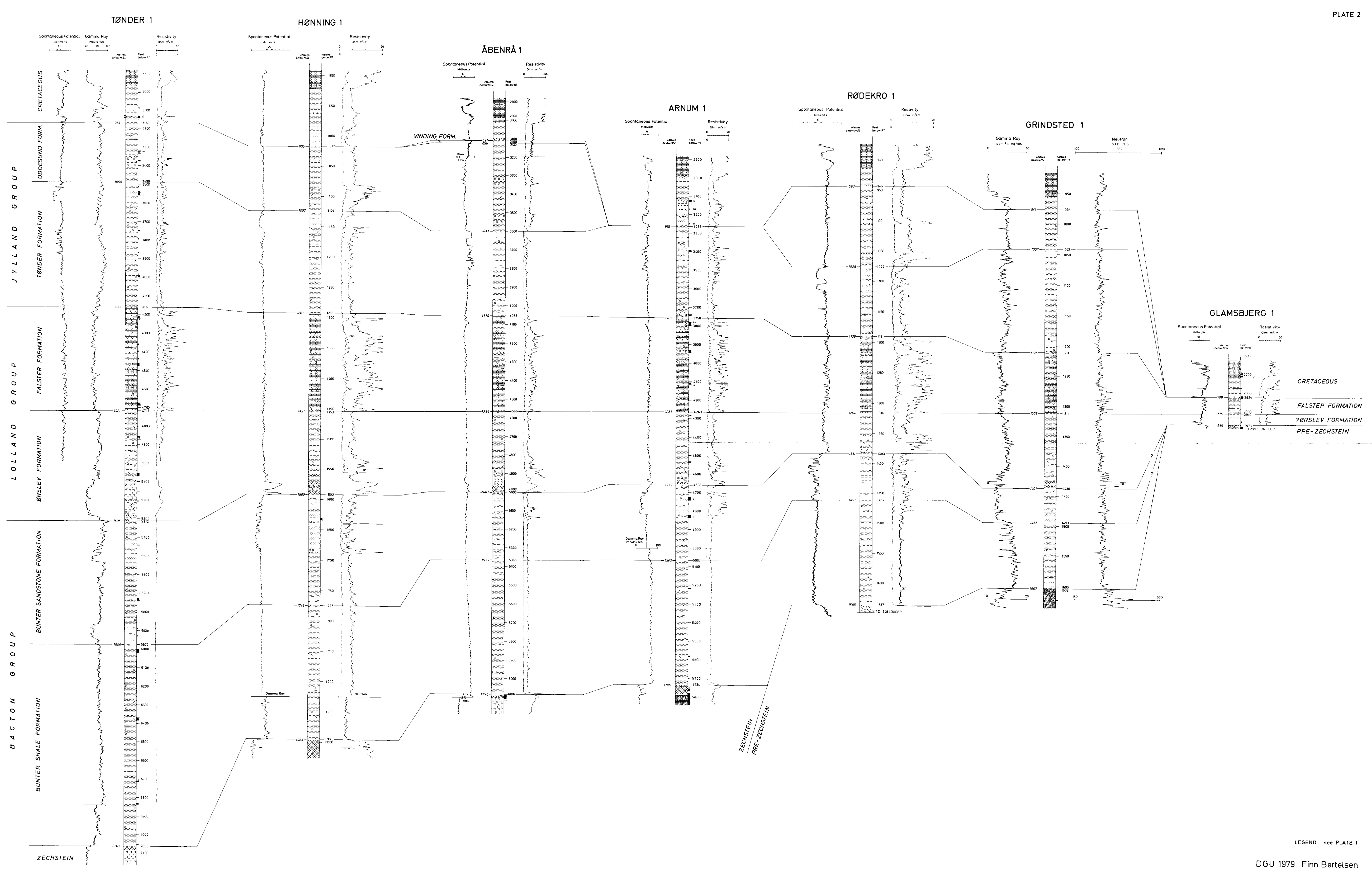


